
UNIVERSIDADE DE SÃO PAULO

INSTITUTO DE GEOCIÊNCIAS

\title{
PARÂMETROS TEXTURAIS DE SEDIMENTOS PARA ELABORAÇÃO DE CARTAS DE SENSIBILIDADE AMBIENTAL AO DERRAMAMENTO DE ÓLEO CARTAS SAO
}

\author{
André Gianotti Stern \\ Orientador: Prof. Dr. Paulo César Boggiani \\ DISSERTAÇÃO DE MESTRADO \\ COMISSÃO JULGADORA \\ Nome \\ Assinatura
}

Presidente: Prof. Dr. Paulo César Boggiani

Examinadores: Prof. Dr.

Prof. Dr.

Prof. Dr.

Prof. Dr.

SÃO PAULO

2007 


\section{Agradecimentos}

Durante esta empreitada, muitos foram os que possibilitaram a sua execução e, de certa forma, contribuíram para diminuição da degradação ambiental deste, ainda esperançoso, país. Penso que o desenvolvimento de uma nação está diretamente relacionado à sua saúde ambiental e isso se reflete na qualidade de vida dos cidadãos.

Para obtenção da presente dissertação de mestrado, agradeço ao meu orientador e amigo, Paulo Boggiani, pela confiança e pelo aprendizado conjunto sobre geociências e relações humanas. Agradeço também à sua esposa, Ana Lucia Desenzi Gesiki, quem muito me ensinou sobre textura sedimentar e preparação de amostras para esse fim e sou grato também aos amigos, que foram ao campo naquele calor infernal, cheio de atoleiros e que muito me ajudaram nessa empreitada como os geólogos, Marlei A. C. Chamani (Trilô), Prof. Renato Paes de Almeida (O Ninguém das llíadas) e Lucas V. Warren (Falconétte).

Externo meus agradecimentos à equipe do Laboratório de Sedimentologia - IGc -USP, em nome de seu responsável Professor Paulo César Giannini, ao grande amigo Isaac Sayeg, a Ana Góes, a Elaine Aparecida da Silva Sinfrônio, Rodolfo Marinho, Victor Ângelo Paulino de Aguiar e Simone Campos Carrera.

Agradeço à FAPESP pelo financiamento deste estudo, através de projeto de auxílio à pesquisa concedido ao Prof. Dr. Paulo César Fonseca Giannini (processo 03/08911-0).

Ao desenvolvimento das investigações geoestatística, devo às orientações do Prof. Dr. Marcelo M. Rocha, ao qual expresso também meus agradecimentos.

Não poderia deixar de mencionar o aprendizado que tive nestes quatro anos de convivência e trabalho no Departamento de Segurança, Meio Ambiente e Saúde da 
Empresa Alpina Briggs, quando tive a oportunidade de participar da elaboração de vinte Atlas Ambientais e Cartas SAO, nos mais diferentes lugares desse Brasil, e essa experiência se reflete nesta dissertação. Com referência aos profissionais dessa empresa, muito sou grato ao Dante Pozzi Neto, (capo), coordenador de uma verdadeira equipe multidisciplinar e que permitiu realização de toda essa empreitada; Helvio Aventurato, gentleman, "o mito" das emergências químicas; Roberto Giannini, oceanólogo, que corrigiu e discutiu o texto comigo; ao mago do GIS e que juntos estivemos em várias "empreitadas" por este país a fora, engenheiro cartógrafo, Luciano Gualberto Chagas, ao pescador, geógrafo, geomorfólogo, pedólogo, zappófilo e palestrino Osvaldo H. Nogueira Jr., ao Capitão Arkadiusz Talaska, aviador e meteorologista, ao engenheiro ambiental Adriano Simões, ao químico e rock'n'roller Felipe E. Melloso (Chicó), Mr. Mark Francis (Briggs Marine UK) e Marco G. Formicola (capo di tutti i capi).

Por fim, agradeço a paciência, ao amor e carinho que tive da minha família. Meu pai Roberto Stern, mãe Mariella Gianotti e irmão Fabio Gianotti Stern (geólogo e palestrino) e a minha querida Paula Zemel. 
Não adianta chorar sobre o óleo derramado... 


\section{Resumo}

STERN, A. G. - 2007. Parâmetros Texturais de Sedimentos Para Elaboração de Cartas de Sensibilidade Ambiental ao Derramamento de Óleo, Cartas SAO. São Paulo, 2007. 96 fls. Dissertação (Mestrado) - Instituto de Geociências, Universidade de São Paulo, São Paulo.

Derramamentos de petróleo geraram 0 aumento da atenção de órgãos governamentais e civis quanto a estudos e técnicas para minimizar os danos aos recursos ambientais e socioeconômicos causados por este tipo de acidente. $O$ desenvolvimento de técnicas e os estudos relacionados à prevenção e resposta aos acidentes busca maior eficiência na resposta à contingência e à diminuição dos danos ambientais e socioeconômicos causados na área atingida. A Carta de Sensibilidade Ambiental ao Derramamento de Óleo (Carta SAO) é uma importante ferramenta para a diminuição de danos causados ao ambiente, para o planejamento ambiental na prevenção e na reposta a acidentes em locais de armazenamento e transporte de hidrocarbonetos, tais como dutos, ferrovias, rodovias, etc. Na Carta SAO, para áreas de exposição de sedimentos e rochas sedimentares, procura-se quantificar e qualificar uma determinada área que apresente vulnerabilidade e sensibilidade ao óleo, ou seja, estipular a área e as características intrínsecas do terreno que apresenta alguma probabilidade de ser atingido por óleo, considerando também atividades de resposta. As características dos sedimentos existentes em áreas vulneráveis permitem a determinação de sua sensibilidade, assim buscou-se estudar os parâmetros sedimentares mais influentes na determinação da sensibilidade ambiental do terreno, como a granulometria e seleção, os quais influenciam a porosidade e permeabilidade do terreno, e o cruzamento dessas informações com a declividade do terreno. A fim de testar a eficiência desses parâmetros, o estudo foi aplicado na Bacia do Ribeirão Tamanduá, na região de Cravinhos (SP), por ser interceptada pelo Duto OSBRA e a área de exposição dos arenitos da Formação Botucatu.

Palavras-chave: Derramamento de óleo; Carta de Sensibilidade Ambiental; Textura sedimentar, Poluição em sedimentos. 


\section{Abstract}

STERN, A. G. - 2007. Sediment Texture Parameters for Elaboration of Environmental Sensitivity Index Maps for Oil Spills. ESI maps. São Paulo, 2007. 96 pages, Masters Dissertation, Geosciences Institute, University of São Paulo, São Paulo, Brazil.

Oil spills have resulted in increased awareness among government and private agencies regarding studies and techniques to minimize damages caused by this type of accident to environmental and socio-economic resources. The development of techniques and the studies for prevention and response to accidents is intended to achieve greater effectiveness in dealing with this type of contingency and to decrease the environmental and socio-economic damage to the areas affected by oil spills. The Environmental Sensitivity Index Map for Oil Spills (ESI Map) is an important tool that helps to decrease the damage caused to the environment. It is also useful in planning prevention and responding to accidents in storage areas and in transporting hydrocarbons, in ducts, by rail, road, etc. The purpose of the ESI Map is to quantify and qualify certain areas of exposed sediments and sedimentary rocks that are vulnerable or present sensitivity to oil. In other words, stipulate the area and the intrinsic characteristics of the ground that may receive an oil spill, and considering the response actions. The characteristics of existing sediments in vulnerable areas allow the determination of the area's sensitivity. As a result, the study focused on the sedimentary parameters with greatest influence in determining the area's environmental sensitivity, such as granulometry and grain selection, which have an influence in the ground's porosity and permeability, and cross-referencing this information with the declivity of the ground. In order to test the efficiency of these parameters, the study was implemented in the Bacia do Ribeirão do Tamanduá, in the Cravinhos (SP) region, because it intercepts the OSBRA oil pipeline and an area with exposed sandstone from the Botucatu Formation.

Keywords: Oil spill; Environmental Sensitivity Index Map; Sedimentary fabric; Pollution in sediments. 


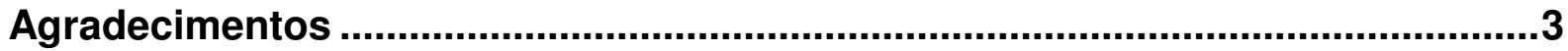

Resumo

Abstract

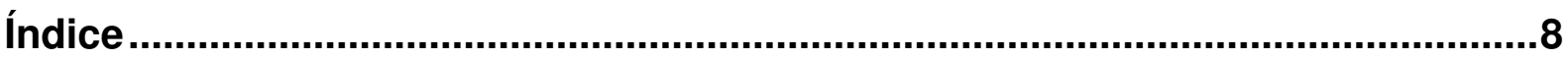

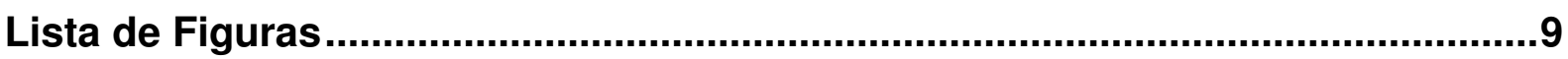

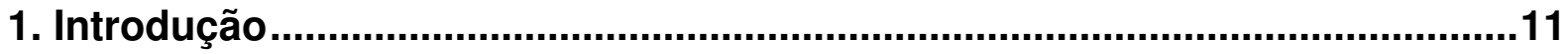

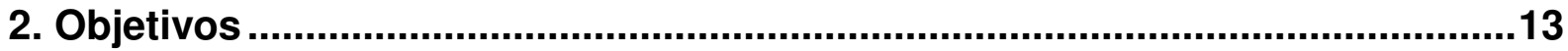

3. Elaboração de Cartas de Sensibilidade Ambiental ao Derramamento de Óleo

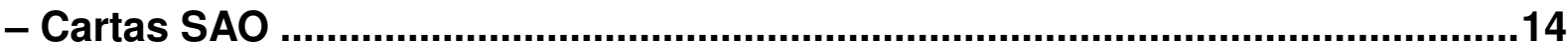

3.1 Métodos empregados em outros países ………...........................................

3.2. Método empregado no Brasil para Elaboração de Carta SAO ……..................23

4. Aspectos conceituais dos parâmetros propostos para a elaboração de Cartas Sensibilidade para Ambientes Continentais...............................................31

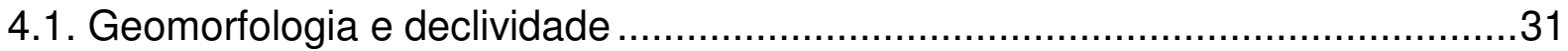

4.2. Textura Sedimentar (Porosidade $x$ Permeabilidade) .......................................33

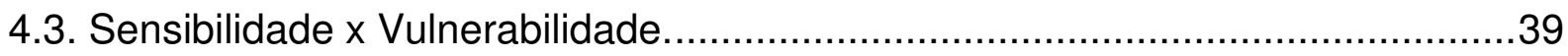

4.4. Derramamento de óleo em áreas continentais ................................................40

4.5. Comportamento dos diferentes hidrocarbonetos no ambiente ........................47

5. Aplicação dos parâmetros texturais na elaboração da Carta SAO da Bacia do Rio do Tamanduá - Cravinhos e São Simão (SP) ………..................................50

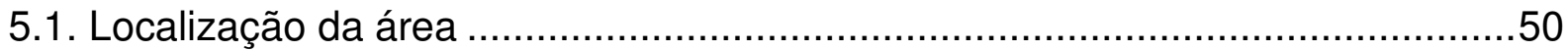

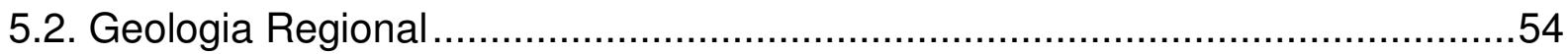

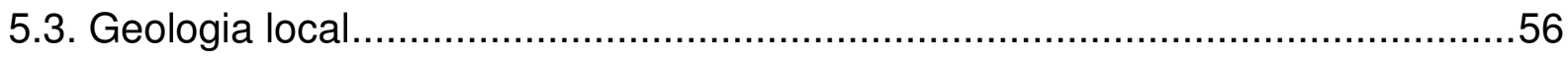

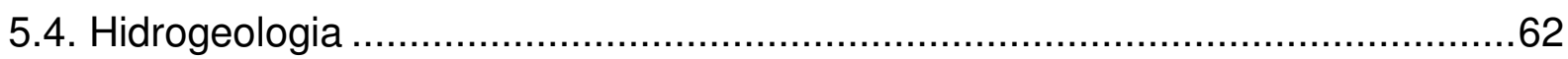

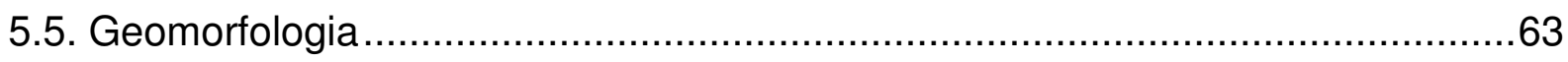

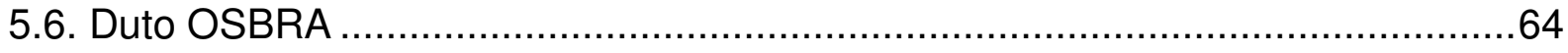

5.7. Utilização de parâmetros texturais na elaboração da Carta SAO da Bacia do

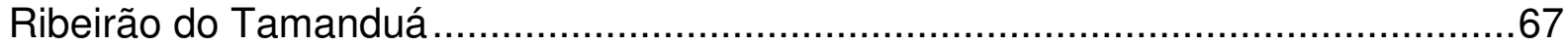

5.8. Avaliação dos parâmetros texturais para elaboração da Carta SAO ………......79

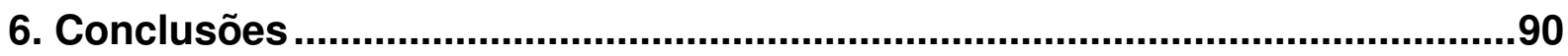

7. Referências Bibliográficas. ........................................................................91 


\section{Lista de Figuras}

Figura 1 - Classificação da rede de drenagem de uma bacia hidrográfica...............16

Figura 2 - Exemplo de Carta SAO para ambientes litorâneos..................................24

Figura 3 - Exemplo de Carta SAO para ambientes continentais (IST). ..................28

Figura 4 - Porosidade x Permeabilidade, em função do tamanho e seleção de grãos

de areia. Modificado de Nagtegaal (1978). .......................................................36

Figura 5 - Classes de seleção de grãos. Modificado de Folk (1968)......................37

Figura 6 - Classes de arredondamento e esfericidade de grãos de areia, modificado

de Powers (1953).

Figura 7 - Persistência do óleo ao meio $x$ dias de exposição ao ambiente. Sendo: I gasolina, II - diesel e óleos leves, III - óleos e produtos intermediários e IV - óleos e produtos pesados e o tempo, dado em dias. Modificado de ITOPF, 1996...............41 Figura 8 - llustração das principais processos de intemperismo, em meio aquoso. Modificado de ITOPF (1996)......................................................................42

Figura 9 - Derrame Terrestre x Costeiro. Modificado de Owens (2002)..................43 Figura 10 - llustração dos três tipos básicos de plumas de infiltração. Modificado de Fussel et. al. (1981)

Figura 11 - Croqui dos acessos principais à área de estudo. Modificado de DER-SP

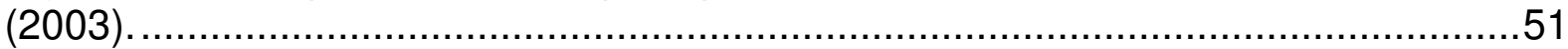

Figura 12 - Ocupação da área de estudo. Eminentemente por canaviais..................51

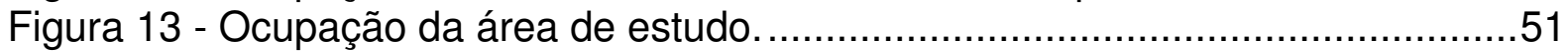

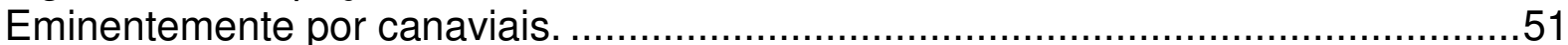

Figura 14 - Área de servidão do duto OSBRA.................................................52

Figura 15 - llustração da área de estudo com aspectos das vias de acesso entre os

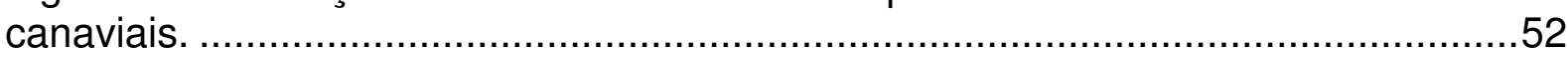

Figura 16 - Ocupação da área de estudo por canaviais .......................................52

Figura 17 - Ocupação da área de estudo por pastagem....................................52

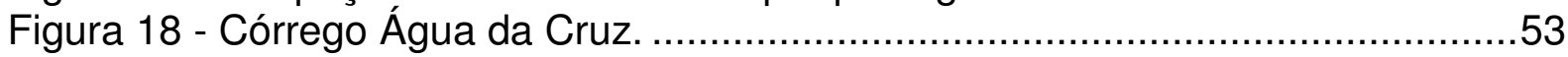

Figura 19 - Ribeirão do Tamanduá................................................................53

Figuras 21 e 22 - Afloramento de basalto da Formação Serra Geral existente na

área de estudo.

Figura 23 - Afloramento de arenito da Formação Botucatu, no Córrego Jaboticabal.

Figuras 24 e 25 - Fotomicrografias de arenitos coletado na área de estudo. A cor azul é dada pelo material de impregnação e demonstra os poros da rocha. ............59 Figuras 26 e 27 - Fotomicrografias de sedimentos predominantemente argiloso com seleção muito pobre, coletados na área de estudo. ...........................................60 Figuras 28 e 29 - Fotos de locais de coletas de amostras da área de estudo. .........61 Figura 30 - Traçado esquemático do oleoduto OSBRA. Modificado de Transpetro,

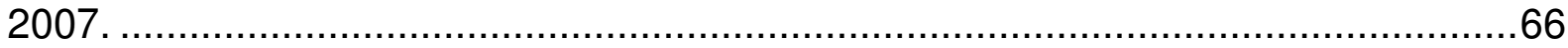

Figura 31 - Faixa de servidão do duto OSBRA, na área de estudo.........................66

Figura 32 - Faixa de servidão do duto OSBRA, na área de estudo.........................67

Figura 33 Primeira etapa: levantamento bibliográfico. ........................................68

Figura $34 \mathrm{~A}$ - A figura acima ilustra a bacia geral da área afetada, com todas as subbacias. Bacia do Ribeirão do Tamanduá, Cravinhos - SP...................................70

Figura 34 B - A figura ilustra a determinação das bacias vulneráveis, ou seja, aquelas que podem receber qualquer quantidade de material derramado e as não vulneráveis, ou seja, aquelas que nada sofrerão. Bacia do Ribeirão do Tamanduá, Cravinhos - SP. (Mapa em maior escala no Anexo A) 
Figura 34 C- A figura acima ilustra a delimitação final da área de estudo e de elaboração da Carta SAO. Nota-se redução da área inicial para a final. Bacia do ribeirão do Tamanduá, Cravinhos - SP. (Detalhes no Anexo B).

Figura 35 - segunda etapa da dissertação, marcado pela determinação de metodologia a parâmetros

Figura 36 - terceira etapa da dissertação, marcado pela aplicação do método e parâmetros em área experimental................................................................76

Figura $37 \mathrm{~A}$ e B - variabilidade espacial dos dados interpolados da área.................84

Figura $38 \mathrm{~A}$, resultado da interpolação do variograma por krigagem ordinária. .........85

Figura $38 \mathrm{~B}$ - resultado da interpolação do variograma por krigagem ordinária........86 Figura 39 - Mapa georreferenciado dos isovalores da granulometria obtido na área

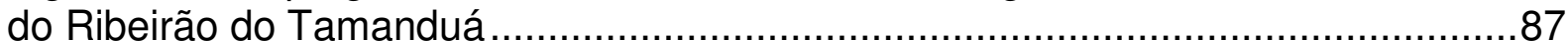
Figura 40 - Mapa georreferenciado dos isovalores da seleção de grãos obtido na área do Ribeirão do Tamanduá. 


\section{Introdução}

Os derramamentos de óleo e derivados são responsáveis por grandes prejuízos ambientais e econômicos, motivo pelo qual, além de se procurar minimizar a ocorrência de acidentes, medidas vêm sendo tomadas no sentido de diminuir os impactos ambientais dos derramamentos, entre elas a elaboração de Cartas de Sensibilidade Ambiental ao Derramamento de Óleo - Cartas SAO, cuja elaboração, para áreas continentais, é objeto de estudo da presente dissertação, com ênfase nos parâmetros texturais de sedimentos condicionantes da porosidade e permeabilidade do meio.

Entre os anos de 1970 e 1980, acidentes com os petroleiros Argo Merchan em 1976 nos EUA, Amoco Cadiz em 1978, na França e, principalmente, o do Exxon Valdez em 1989, no Alaska, resultaram no aumento da atenção de órgãos governamentais e civis quanto ao desenvolvimento de estudos e técnicas para minimizar os danos aos recursos ambientais e socioeconômicos causado por derramamento de óleo.

Existem atualmente amplo conhecimento e levantamentos a respeito de derramamento de óleo em meio oceânico e litorâneo, porém pouco se tem desenvolvido a respeito de derramamentos em meio continental e fluvial.

No Brasil, poucos são os dados disponíveis sobre derramamentos ocorridos. O primeiro derramamento que se tem notícia, registrado pela CETESB (Companhia de Tecnologia de Saneamento Ambiental, do Estado de São Paulo), foi o do petroleiro Brazilian Marina, em 1978, com derramamento de $6.000 \mathrm{~m}^{3}$ de óleo no litoral de São Sebastião.

Com relação aos derramamentos em áreas continentais no Brasil, existe o registro do acidente da refinaria REPAR, ocorrido em 2000, em Araucária (PR), com 
derramamento de $150.000 \mathrm{~m}^{3}$ de óleo nos rios Barigüi e Iguaçu, e em 2001, na Refinaria de Paulínia (REPLAN), Paulínia (SP), quando a ruptura de um duto causou o vazamento de $220 \mathrm{~m}^{3}$ de combustível.

$\mathrm{Na}$ presente dissertação, foram estudados os parâmetros sedimentares que determinam a sensibilidade ambiental do terreno pelas características de sua porosidade, permeabilidade, a partir de informações dadas pelo tamanho e seleção de grãos, e declividade das bacias vulneráveis ao derramamento de óleo. A partir destes parâmetros foi confeccionada uma Carta SAO para a Bacia do Ribeirão do Tamanduá, em Cravinhos e São Simão, Estado de São Paulo, área escolhida por ser de exposição de arenitos da Formação Botucatu, constituinte do Sistema Aqüífero Guarani e cortada pelo duto OSBRA da Refinaria de Paulínia (Petrobras). 


\section{Objetivos}

O presente estudo tem como objetivo a análise dos parâmetros sedimentares texturais que influenciam na permeabilidade de sedimentos e rochas sedimentares e a aplicação desses parâmetros na elaboração de Cartas de Sensibilidade Ambiental ao Derramamento de Óleo - Cartas SAO - em áreas de exposição de sedimentos arenosos e rochas sedimentares.

A aplicação dos estudos dos parâmetros texturais, na elaboração de Carta SAO, foi realizada no Vale do Ribeirão do Tamanduá, cortado pelo oleoduto OSBRA da Petrobras, nos municípios de Cravinhos e São Simão, Estado de São Paulo, onde se encontram expostos arenitos da Formação Botucatu, rochas-reservatório do Sistema Aqüífero Guarani. 


\section{Elaboração de Cartas de Sensibilidade Ambiental ao Derramamento de Óleo}

\section{- Cartas SAO}

Para o estudo dos parâmetros texturais de sedimentos necessários para elaboração de Cartas SAO, foi realizada análise de métodos utilizados no exterior e no Brasil, tanto para elaboração dessas cartas como os que tratam de vulnerabilidade e risco ao meio ambiente, causados por inúmeros agentes poluidores, principalmente o óleo e derivados.

\subsection{Métodos empregados em outros países}

Órgãos governamentais, associações e empresas ambientais de outros países que lidam com óleo, como a US-EPA (Environmental Protection Agency), Environmental Canada, API (American Petroleum Institute), IMO (International Maritime Organization), IPIECA (International Petroleum Industry Environmental Conservation Association), ITOPF (International Tankers Owners Pollution Federation Limited), entre outras instituições, elaboraram métodos e técnicas que buscam maior eficiência e rapidez nos trabalhos de contingência e resposta, buscando a minimização dos danos causados pela contaminação do meio pelo petróleo e derivados, onde a Carta SAO é o principal instrumento.

Os métodos descritos e analisados nesta dissertação foram escolhidos por serem amplamente utilizados e por abordarem aspectos relevantes para o entendimento e seleção dos parâmetros de geologia sedimentar necessários na elaboração de Cartas SAO.

A base para elaboração de Cartas SAO tem sido a indexação das áreas sujeitas ao derramamento conforme sua vulnerabilidade, sendo que Gundlach e Hayes (1978) foram os primeiros a apresentar uma classificação do gênero para 
feições geomorfológicas da linha de costa. Esse trabalho baseou-se nos acidentes ocorridos na década de setenta do Século 20, como os dos navios petroleiros Argo Merchant, Metula, Sansinena, Urquilla e os ocorridos no rio Tâmisa (Inglaterra), e nos rios Delaware e Hudson (EUA).

No trabalho de Gundlach e Hayes (1978), foi desenvolvida indexação das feições geomorfológicas costeiras numa escala de 1 a 10 em termos de sua vulnerabilidade, com ênfase no tempo de residência do óleo, e considerando o impacto biológico inicial e a energia do ambiente, a qual estaria associada à permanência do óleo. Com base nesse princípio, a indexação seria relativa sendo a de número 1 as áreas de maior vulnerabilidade, como as de mangue, face à baixa energia de dispersão dos poluentes e alta sensibilidade ambiental, devido às suas características biológicas, e a de número 10 a de menor vulnerabilidade como os costões rochosos, sujeitos à ação de ondas o que diminuiria a permanência do óleo nesses ambientes.

A ocorrência de acidentes em áreas continentais demonstrou a necessidade de estudos específicos para essas áreas, frente aos diferentes comportamentos do óleo. Para os derramamentos oceânicos, e mesmo para os litorâneos, não se tem muita preocupação com a infiltração do hidrocarboneto e possível contaminação da água subterrânea, o que já passa a ser a maior preocupação no caso de acidentes em áreas continentais.

Para áreas continentais, os limites das áreas passam a ser o das bacias hidrográficas que podem ser afetadas, como os estudos realizados por Hayes et. al. (1994), onde os termos vulnerabilidade e sensibilidade são sinônimos.

No método apresentado em Hayes et. al. (1994) para rede de drenagens, foi mantido o parâmetro de energia do meio, devido à relação desse com a 
permanência do óleo no ambiente, onde a modelagem da bacia é dada pela energia de cada drenagem, divida em três classes: A - de gradiente moderado, canais pouco retilíneos, correntes rápidas, corredeiras intermitentes e barras de areia e cascalho; B - de gradiente intermediário, longas áreas de vegetação de áreas alagadas e C - alto gradiente, íngreme, canais entrelaçados e retilíneos, fortes correntes, canais e margens com areia e cascalho, quedas d'água e zonas restritas de vegetação e áreas alagadas (figura 1).

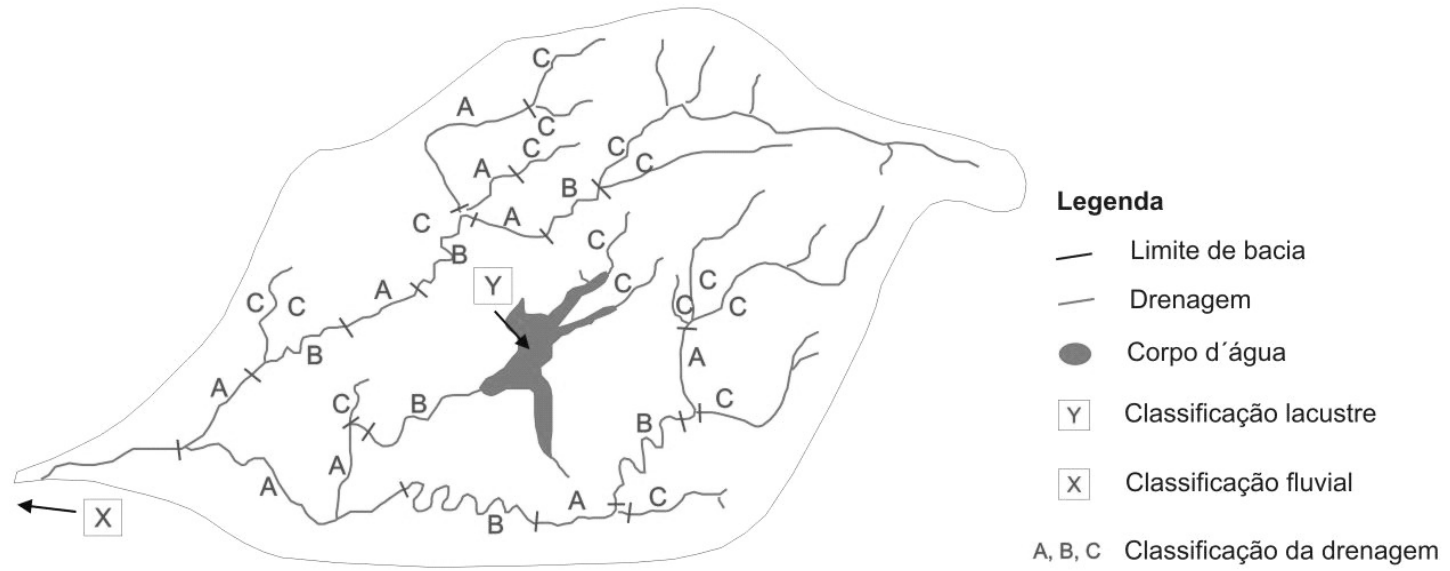

Figura 1 - Classificação da rede de drenagem hipotética de uma bacia hidrográfica vulnerável ao derramamento de óleo. Modificado de Hayes et. al. (1994).

Ainda em 1994, outro método foi apresentado pela API e NOAA (1994) em relatório intitulado Inland Oil Spills - Options for Minimizing Environmental Impacts of Freshwater Spill Response, com apresentação de técnicas para minimizar o impacto ambiental negativo causado por hidrocarbonetos em ambientes continentais. Nesse método, o tipo de hidrocarboneto envolvido no acidente passou também a ser considerado, e não apenas a classificação do tipo de ambiente.

No método da API e NOAA (1994), foi demonstrada também maior preocupação com o meio biótico, o qual recebe uma classificação da sensibilidade do habitat em função do tempo de residência do óleo nesse ambiente, acrescido do 
tipo de resposta para a remoção e limpeza do óleo. São também consideradas características sazonais, como a variação do nível de água, nos períodos de cheias e secas, e tipo de vegetação, e capacidade de remediação natural.

$\mathrm{Na}$ tabela 1 é apresentada a correlação de habitat continentais apresentadas na publicação da API e NOAA (1994) comparada aos Índices de Sensibilidade Ambiental (ESI, Environmental Sensitivity Index) estabelecidos pela Environmental Canada e US-EPA para áreas litorâneas, estudo esse desenvolvido de forma específica para a região dos Grandes Lagos, fronteira entre os EUA e Canadá.

Tabela 1 adaptado de API e NOAA (1994).

\begin{tabular}{|c|c|}
\hline API e NOAA (1994) & Environmental Canada e US-EPA \\
\hline Hábitat e Margens & ESI ranking e descrição \\
\hline \multirow{3}{*}{ Embasamento Cristalino } & $\mathrm{ESI}=01 \mathrm{~A}-$ Cliffs de rocha exposta \\
\hline & ESI $=02-$ Costões rochosos \\
\hline & $\mathrm{ESI}=08 \mathrm{~A}-$ Praias abrigadas de rocha \\
\hline \multirow{3}{*}{ Estruturas Antrópicas } & ESI=01B - Muros de contenção, expostos. \\
\hline & ESI=06B - Estruturas tipo Rip-rap \\
\hline & ESI=08B - Estruturas sólidas Abrigadas \\
\hline Areia & $\mathrm{ESI}=04-$ Praias/barras de areia \\
\hline \multirow{2}{*}{$\begin{array}{l}\text { Sedimentos Grossos (areia + } \\
\text { cascalho) }\end{array}$} & $\begin{array}{c}\text { ESI=03 - Barrancas erodidas e } \\
\text { inconsolidadas }\end{array}$ \\
\hline & ESI=05 - Praias/barras de areia e cascalho \\
\hline Cascalho & $\mathrm{ESI}=06 \mathrm{~A}-$ Praias/barras de cascalho \\
\hline Linhas de Costa Vegetadas & $\mathrm{ESI}=09 \mathrm{~A}-$ Praias $/$ barras $/$ margens vegetadas \\
\hline Lama & $\begin{array}{c}\text { ESI=9B }- \text { Planícies abrigadas de areia ou } \\
\text { lama }\end{array}$ \\
\hline \multirow{2}{*}{ Áreas alagadas } & ESI=10A - Pântanos descontínuos (franja) \\
\hline & $\mathrm{ESI}=10 \mathrm{~B}-$ Pântanos extensos \\
\hline
\end{tabular}


No método API e NOAA (1994) são também considerados os distúrbios físicos causados pelas técnicas de limpeza e remoção do óleo, classificando essas técnicas como de distúrbios baixo, moderado e alto, causados pelos métodos mecânicos e o impacto tóxico de métodos químicos e biológicos de atenuação.

O distúrbio baixo ocorre quando os danos físicos ao substrato e à vegetação são mínimos e os impactos tóxicos estão limitados a áreas restritas, onde, nesses casos, consegue-se a recuperação em menos de seis meses. O distúrbio moderado ocorre quando os danos físicos no subsolo e na vegetação potencialmente podem ocorrer em decorrência dos trabalhos de resposta e remoção como, por exemplo, pela ação intensa de tratores, causando o aumento da erosão. Nesses casos, a recuperação se dá entre seis e doze meses. Já no distúrbio alto, quando são esperados danos físicos no subsolo e vegetação e nos trabalhos de resposta ao derrame o meio ambiente será mais afetado (face à grande quantidade de operadores, materiais e maquinário envolvidos), a recuperação da área se dará em mais de doze meses.

Nota-se que no método API e NOAA (1994) o objetivo principal é evitar ao máximo o contato do óleo com os ambientes. Desta forma os derramamentos são divididos em duas classes: os que ocorrem no meio do corpo de água, sem tocar as margens, onde a resposta se restringe à contenção, proteção e coleta do produto para que não atinja alguma margem, e aqueles que atingem a interface terra - água, mais problemáticos, onde a atividade de resposta está relacionada à proteção, recuperação e limpeza do habitat.

Em 1996, outro método foi elaborado e apresentado no relatório Sensitivity Mapping for Oil Spill Response, elaborado pela IMO e IPIECA (1996), o qual apresenta como marco o consenso entre as exigências dos órgãos ambientais 
governamentais e a indústria para a cooperação internacional no combate aos incidentes de derramamento de óleo.

No método da IMO e IPIECA (1996), é proposto elaboração de cartas com informações essenciais para resposta ao derramamento de óleo para ambientes continentais com indicação das áreas sensíveis. As classificações a serem apresentadas nas áreas individualizadas nessas cartas reúnem as características das linhas de costas e tem por objetivo orientar os trabalhos de resposta aos possíveis acidentes. Nesse método, as cartas de sensibilidade apresentam maior variedade de informações relacionadas a diversas categorias de derramamento de óleo e as escalas de mapeamentos propostas dependem do volume potencial de derramamento, divididos em três níveis: a) Tier 1 relacionados a pequenos derramamentos, provenientes de instalações fixas, situações nas quais os mapeados devem ser elaborados na escala $1: 10$ 000; b) Tier 2 relacionados a acidentes de tamanho médio, normalmente distantes de instalações industriais e com potencial de grande impacto ao meio, com mapeados propostos na escala 1:100 000 e c) Tier 3 relacionados a grandes acidentes, com derramamento de milhares de toneladas de óleo, com potencial de causar grandes danos ao meio em grandes áreas, onde os mapas devem ser mais abrangentes e na escala 1:1.000.000.

O relatório elaborado pela NOAA (1997) estabelece o índice de sensibilidade ambiental (ESI, Environmental Sensitivity Index, ou ISA, Índice de Sensibilidade Ambiental) como parte de planos de contingência e resposta ao derramamento de óleo desde 1979, quando foram produzidos os primeiros mapas de sensibilidade ambiental ao derramamento de óleo para o Golfo do México, após a explosão do poço de produção Ixtoc, próximo a Yucatán, em 1979. 
Como o objetivo principal das Cartas SAO é o de possibilitar uma rápida resposta aos derramamentos de óleo, em 1997 foram estabelecidos pela NOAA (1997) o índice de sensibilidade ambiental (ESI, Environmental Sensitivity Index, ou ISA, Índice de Sensibilidade Ambiental) e a representação desses nas cartas através de ícones de fácil reconhecimento e identificação. Desta forma, as Cartas SAO foram acrescidas de representações por símbolos de locais de maior interesse ambiental e social, tais como locais de desova de tartarugas, tanques de criação, pesca artesanal, marinas, áreas de especial interesse turístico, etc.

Essa sistemática passou a ser uma constante em todas as Cartas SAO, inclusive no Brasil, com exemplos de Ícones utilizados para indicar ocupação e uso socioeconômico e da presença de animais na Tabela 2.

Tabela 2. - Exemplos de Ícones utilizados em Cartas SAO como os exigidos pelo Ministério do Meio Ambiente (Brasil).

\begin{tabular}{|c|c|c|c|c|}
\hline \multicolumn{5}{|c|}{ Ícones } \\
\hline (0) & $A Q$ & $\bullet$ & (x) & A \\
\hline $\begin{array}{c}\text { Tomada de } \\
\text { água }\end{array}$ & Aqüicultura & Dutovia & Mineração & $\begin{array}{c}\text { Sitio } \\
\text { arqueológico }\end{array}$ \\
\hline & (18) & & $\pi$ & 5 \\
\hline Ave marinha & $\begin{array}{l}\text { Mamífero } \\
\text { terrestre }\end{array}$ & Quelônios & Crustáceos & Cetáceos \\
\hline
\end{tabular}

Na tabela 3, é apresentada classificação de feições para ambientes estuarinos, lacustres e fluviais na confecção de Cartas SAO de acordo com a classificação de NOAA (1997). A escala da tabela baseia-se no entendimento das características físicas e biológicas de cada ambiente costeiro e não somente por parâmetros como o tipo de substrato, mas por fatores como a exposição à energia de ondas e marés, geomorfologia costeira ou da margem, tipo de substrato (tamanho do grão, mobilidade, percolação, etc.) e relativos à sensibilidade ambiental e a produtividade biológica. 
Tabela 3 - Classificação ambiental para a confecção de Cartas SAO. Modificada de NOAA (1997).

\begin{tabular}{|c|c|c|c|}
\hline ISA & Ambiente Estuarino & Ambiente Lacustre & Ambiente Fluvial \\
\hline $1 \mathrm{~A}$ & Costão rochoso exposto & $\begin{array}{l}\text { Costão rochoso } \\
\text { exposto }\end{array}$ & $\begin{array}{l}\text { Costão rochoso } \\
\text { exposto }\end{array}$ \\
\hline 1B & $\begin{array}{l}\text { Estrutura antrópica } \\
\text { sólida exposta }\end{array}$ & $\begin{array}{l}\text { Estrutura antrópica } \\
\text { sólida exposta }\end{array}$ & $\begin{array}{l}\text { Estrutura antrópica } \\
\text { sólida exposta }\end{array}$ \\
\hline $2 \mathrm{~A}$ & $\begin{array}{l}\text { Plataforma quebra-mar } \\
\text { (rocha ou lama) }\end{array}$ & $\begin{array}{l}\text { Costão rochoso } \\
\text { inclinado }\end{array}$ & $\begin{array}{l}\text { Baixio ou } \\
\text { afloramento } \\
\text { rochoso }\end{array}$ \\
\hline $2 B$ & $\begin{array}{l}\text { Escarpa íngremes } \\
\text { expostas argilosas. }\end{array}$ & - & 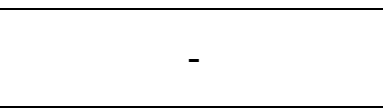 \\
\hline $3 \mathrm{~A}$ & $\begin{array}{l}\text { Praia de areia fina-a- } \\
\text { média. }\end{array}$ & $\begin{array}{l}\text { Escarpas erodidas de } \\
\text { sedimentos } \\
\text { inconsolidados. }\end{array}$ & $\begin{array}{l}\text { Margem exposta } \\
\text { erodidas com } \\
\text { sedimento } \\
\text { inconsolidado. }\end{array}$ \\
\hline 3B & Escarpa arenosa. & - & \\
\hline 4 & $\begin{array}{c}\text { Praias de areia grossa e } \\
\text { cascalho. }\end{array}$ & Praia de areia. & $\begin{array}{l}\text { Barra de areia e } \\
\text { margem suave. }\end{array}$ \\
\hline 5 & $\begin{array}{l}\text { Praias com areia e } \\
\text { cascalho misturados. }\end{array}$ & $\begin{array}{l}\text { Praias com areia e } \\
\text { cascalho misturados. }\end{array}$ & $\begin{array}{c}\text { Praia com areia e } \\
\text { cascalho misturado, } \\
\text { com margem } \\
\text { suave. }\end{array}$ \\
\hline $6 \mathrm{~A}$ & Praia de cascalho & Praia de cascalho. & $\begin{array}{l}\text { Barra de cascalho e } \\
\text { margem suave. }\end{array}$ \\
\hline $6 \mathrm{~B}$ & Rip-rap & Rip-rap & Rip-rap \\
\hline 7 & $\begin{array}{l}\text { Planície de maré } \\
\text { exposta. }\end{array}$ & $\begin{array}{l}\text { Planície de maré } \\
\text { exposta. }\end{array}$ & - \\
\hline $8 \mathrm{~A}$ & $\begin{array}{l}\text { Costa e escarpas de } \\
\text { rocha ou argila } \\
\text { abrigadas. }\end{array}$ & $\begin{array}{l}\text { Costa e escarpas de } \\
\text { rocha ou argila } \\
\text { abrigadas. }\end{array}$ & - \\
\hline 8B & $\begin{array}{l}\text { Estrutura antrópica } \\
\text { sólida abrigada. }\end{array}$ & $\begin{array}{l}\text { Estrutura antrópica } \\
\text { sólida abrigada. }\end{array}$ & $\begin{array}{l}\text { Estrutura antrópica } \\
\text { sólida abrigada. }\end{array}$ \\
\hline $8 \mathrm{C}$ & Rip-rap abrigado & Rip-rap abrigado & Rip-rap abrigado \\
\hline $8 \mathrm{D}$ & Barranco vegetado & - & Barranco vegetado \\
\hline $9 \mathrm{~A}$ & $\begin{array}{c}\text { Planície de maré } \\
\text { abrigada }\end{array}$ & $\begin{array}{c}\text { Planície de maré } \\
\text { abrigada }\end{array}$ & \\
\hline 9B & Margem baixa vegetada & $\begin{array}{c}\text { Margem baixa vegetada } \\
\text { abrigada }\end{array}$ & $\begin{array}{l}\text { Margem baixa } \\
\text { vegetada }\end{array}$ \\
\hline $10 \mathrm{~A}$ & Marismas & & \\
\hline $10 \mathrm{~B}$ & \multirow{3}{*}{ Manguezal } & Brejo de água doce & Brejo de água doce \\
\hline $10 \mathrm{C}$ & & \multirow{2}{*}{ Pântano } & \multirow{2}{*}{ Pântano } \\
\hline $10 \mathrm{D}$ & & & \\
\hline
\end{tabular}

A maioria dos mapas de sensibilidade baseia-se na indexação das feições da linha de costa, em 10 níveis representando a sensibilidade do litoral, baseados no 
trabalho clássico de Gundlach e Hayes (1978). Segundo IMO e IPIECA (1996), na elaboração de Cartas SAO devem ser realizadas adaptações às especificidades regionais, utilizando-se ou desenvolvendo outras indexações e classificações de feições dos meios físico, biológico e socioeconômico entre outros parâmetros que se julgue necessário.

Outros métodos foram elaborados voltados a acidentes com outros tipos de produtos químicos e não somente hidrocarbonetos, como o de Davis e Wireman (2002), desenvolvido especialmente para terrenos cársticos. Nesse método a classificação do meio baseia-se em parâmetros formadores das zonas vadosa e freática, frente a sua contaminação por produtos químicos, pelo desenvolvimento do método norma intitulada KARSTIC, derivada da norma denominada DRASTIC da EPA, onde se define o potencial de poluição pela combinação de fatores hidrogeológicos, influências antropogênicas e fontes de contaminação em determinado sítio.

No método KARSTIC, a sensibilidade é determinada pela acessibilidade à zona saturada e a capacidade de atenuação do material geológico entre a superfície da terra e a zona saturada. Nesse método, é enfatizado o uso de dados existentes para avaliar a sensibilidade em áreas de pequenas dimensões em três etapas. A primeira etapa rege a divisão da área de interesse em seções hidrogeológicas baseado no tipo de rocha, estruturas geológicas e limites de aqüíferos mapeáveis, e características e vulnerabilidade hidrogeológicas comuns à contaminação por poluentes introduzidos. A segunda etapa rege a caracterização destas áreas pela classificação de parâmetros como o tipo de aqüífero, condutividade hidráulica, zona vadosa, nível da água, taxa de recarga, tipo de solo e relevo. A terceira e última etapa resulta na obtenção de valor numérico, classificado num índice de 
sensibilidade de cinco níveis, calculado pelo produto de cada classe por um peso determinado, variando de acordo com as características hidrogeológicas e a bacia de drenagem é subdividida em áreas geográficas baseadas no potencial relativo de poluição.

\subsection{Método empregado no Brasil para Elaboração de Carta SAO}

No Brasil, as normas de elaboração de Cartas SAO, estabelecidas pelo Ministério do Meio Ambiente, têm por base o método NOAA (1997) e são apresentadas em "Especificações e Normas Técnicas para a Elaboração de Cartas de Sensibilidade Ambiental para Derramamentos de Óleo" (MMA 2002).

No método adotado pelo MMA, voltado para áreas costeiras, a Carta SAO tem como componente essencial a fonte de informação primária para o planejamento da contingência e avaliação dos danos causados ao meio ambiente resultantes de vazamentos de óleo. Segue como nos demais métodos, o balizamento de ações de resposta a acidentes com óleo, possibilitando a identificação de ambientes com prioridade de proteção, direcionamento dos recursos disponíveis e mobilização mais eficiente possível das equipes de contenção, remoção e limpeza.

A escala de mapeamento não é pré-determinada pela norma do MMA, podendo ser aplicada em diversos graus de detalhamento, dependendo do interesse de resposta. Assim, se o projeto levar em conta aspectos estratégicos, de resposta e da dimensão do derramamento, terá escala regional; se táticos, escala intermediária e se operacional, escala em detalhe.

No método do MMA, a linha de costa é classificada utilizando-se o Índice de Sensibilidade Litorâneo (ISL), de forma semelhante ao ISA (Índice de Sensibilidade Ambiental) do método NOAA (1997), conforme comparação da tabela 4. Através 
desses índices, as feições costeiras são classificadas em escala de dez níveis, onde, quanto maior o nível, mais sensível ao derramamento de óleo é determinado trecho da costa. Nesta classificação, a geomorfologia litorânea é subdivida com base em sua energia (ondas e marés), declividade e tipo de substrato. A combinação destes parâmetros resulta no padrão de comportamento do óleo com a linha de costa, permitindo prever o grau de impacto, sua interação com o meio e a adequação das técnicas de contingência, remoção e limpeza do óleo. Na tabela 4 é apresentada comparação entre as classificações apresentadas pela NOAA (1997) e a classificação da linha de costa brasileira MMA (2002).

Nas Cartas SAO elaboradas segundo os critérios do MMA (2002), as sensibilidades das áreas costeiras são representadas através de linhas coloridas, e os recursos biológicos e socioeconômicos através de ícones. Na figura 2 é apresentado exemplo de Carta SAO para ambientes litorâneos, onde a sensibilidade da linha de costa, dado pela ISL, é representada por linhas coloridas e as informações sobre a biota e aspectos socioeconômicos por ícones.

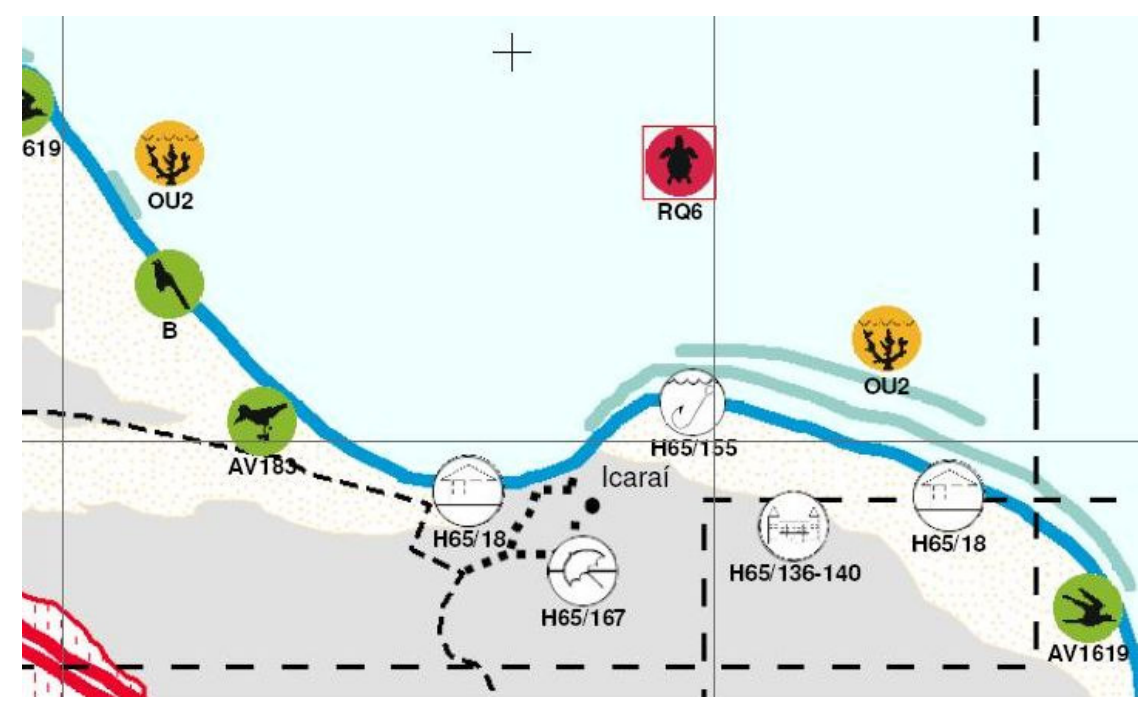

Figura 2 - Exemplo de Carta SAO para ambientes litorâneos. 
Tabela 4. - Comparação entre as classificações NOAA (1997) e MMA (2002).

\begin{tabular}{|c|c|c|}
\hline Índices & Classificação NOAA & $\begin{array}{l}\text { Classificação da Costa Brasileira } \\
\text { MMA }\end{array}$ \\
\hline 1 & $\begin{array}{l}\text { Molhes expostos e outras estruturas } \\
\text { sólidas impermeáveis }\end{array}$ & $\begin{array}{l}\text { Costões rochosos lisos, falésias em } \\
\text { rochas sedimentares de alta } \\
\text { declividade e estruturas artificiais } \\
\text { lisas expostos. }\end{array}$ \\
\hline 2 & $\begin{array}{c}\text { Escarpas Plataformas e taludes } \\
\text { íngremes de argila erodidas pelas } \\
\text { ondas }\end{array}$ & $\begin{array}{l}\text { Costões rochosos lisos, terraços ou } \\
\text { substratos exumados bem } \\
\text { consolidados de declividade média, } \\
\text { expostos. }\end{array}$ \\
\hline 3 & $\begin{array}{l}\text { Praias de areia fina e escarpas e } \\
\text { taludes íngremes de areia. }\end{array}$ & $\begin{array}{c}\text { Praias dissipativas de areia média a } \\
\text { fina, Faixas arenosas contíguas à } \\
\text { praia, não vegetadas, sujeitas à } \\
\text { ação de ressacas (tipo long beach), } \\
\text { escarpas e taludes íngremes (tipo } \\
\text { tabuleiros litorâneos), Campos de } \\
\text { dunas expostos. }\end{array}$ \\
\hline 4 & Praias de areia grossa. & $\begin{array}{c}\text { Praias de areia grossa, } \\
\text { intermediárias de areia fina à média, } \\
\text { expostas e praias de areia fina a } \\
\text { média, abrigadas. }\end{array}$ \\
\hline 5 & $\begin{array}{c}\text { Praias mistas de areia e cascalho (ou } \\
\text { conchas). }\end{array}$ & $\begin{array}{l}\text { Praias mistas de areia e cascalho, } \\
\text { ou conchas e fragmentos de corais, } \\
\text { terraço ou plataforma de abrasão de } \\
\text { superfície irregular ou recoberta de } \\
\text { vegetação e recifes areníticos em } \\
\text { franja. }\end{array}$ \\
\hline 6 & $\begin{array}{c}\text { Praias de cascalho (ou de conchas) e } \\
\text { enrocamentos expostos. }\end{array}$ & $\begin{array}{l}\text { Praias de cascalho (seixos e } \\
\text { calhaus), costa de detritos calcários, } \\
\text { depósito de tálus, enrocamentos (rip- } \\
\text { rap, quebra-mar) expostos, } \\
\text { plataforma ou terraço exumado } \\
\text { recoberto por concreções lateríticas }\end{array}$ \\
\hline 7 & $\begin{array}{l}\text { Planícies de maré (inundáveis) } \\
\text { expostas }\end{array}$ & $\begin{array}{l}\text { Planície de maré arenosa exposta e } \\
\text { terraço de baixa-mar }\end{array}$ \\
\hline 8 & $\begin{array}{c}\text { Estruturas artificiais sólidas abrigadas } \\
\text { (piers, molhes), enrocamentos e } \\
\text { escarpas abrigadas. }\end{array}$ & $\begin{array}{c}\text { Escarpa / encosta de rocha lisa, não } \\
\text { lisa e íngremes de areias, } \\
\text { enrocamentos (rip-rap e outras } \\
\text { estruturas artificiais não lisas) } \\
\text { abrigados. }\end{array}$ \\
\hline 9 & $\begin{array}{c}\text { Planícies de maré abrigadas e } \\
\text { margens de rios com gramíneas e } \\
\text { árvores. }\end{array}$ & $\begin{array}{l}\text { Planície de maré arenosa ou lamosa } \\
\text { abrigada e úmida costeira não } \\
\text { vegetada, terraço de baixa-mar } \\
\text { lamoso abrigado e recifes areníticos } \\
\text { suporte para colônias de corais. }\end{array}$ \\
\hline 10 & $\begin{array}{l}\text { Pântanos salobros e salgados, de } \\
\text { água doce (vegetação herbácea e de } \\
\text { mata) }\end{array}$ & $\begin{array}{c}\text { Deltas e barras de rio vegetadas, } \\
\text { terraços alagadiços, banhados, } \\
\text { brejos, margens de rios e lagoas, } \\
\text { manguezal, etc. }\end{array}$ \\
\hline
\end{tabular}


A escala de classificação de sensibilidade (ISL) não representa uma ordem de grandeza absoluta, e sim comparativa. Um determinado sítio classificado como ISL 5 não tem sensibilidade cinco vezes maior do que o ISL 1 . O índice, bem como o ícone, indica o quadro ambiental do sítio, permitindo a interpretação das informações contidas na Carta SAO de acordo com as condições momentâneas encontradas pela equipe de contingência e resposta.

Estudos sobre a sensibilidade ambiental para áreas continentais, no Brasil, foram primeiramente realizados pela Transpetro S/A, na década de 1980, na caracterização ambiental das sub-bacias hidrográficas cortadas por dutovias. Nesses trabalhos, a sensibilidade ambiental do meio era classificada em apenas três níveis: alto, médio e baixo (apud Oliveira et al. 2003).

Oliveira et. al. (2003) elaboraram classificação para ambientes terrestres e fluviais, mantendo a classificação dos meios físico e socioeconômico através de índices de sensibilidade ambiental, denominado Índice de Sensibilidade Terrestre (IST), dividindo-os em cinco níveis, correspondentes às 10 escalas de feições geomorfológicas, similares àquelas empregadas pela NOAA (1997) e MMA (2002).

No método apresentado por Oliveira et. al. (2003), o derramamento de óleo em áreas terrestres é considerado através de três parâmetros básicos, ou seja, trajetória, espalhamento e permanência, uma vez que esses influenciam diretamente na interação do óleo com o terreno.

$\mathrm{Na}$ trajetória considera-se o escoamento do óleo pelo terreno, determinado pela declividade e tipo de relevo, o que permite a predição da direção do derramamento. A rede de drenagem é o elemento principal neste parâmetro, possibilitando rápido deslocamento do fluído. 
No espalhamento considera-se a penetração do fluido no terreno quanto atingir alguma área exposta ou a rede de drenagem. Caso atinja a drenagem, deve-se considerar as feições fluviais como corpos d'água, planícies de inundação, áreas alagadas, meandros abandonados, etc., como elementos determinantes no espalhamento do óleo.

Na permanência observam-se dois aspectos: o tempo de retenção do fluido no terreno, em relação à interação como o meio e a dificuldade de remoção, em relação ao aumento da interação. Quanto maior a interação do óleo com o meio, mais difícil será a sua remoção, resultando em danos ambientais maiores.

Através do Índice de Sensibilidade Terrestre (IST) são classificadas as áreas quanto à vulnerabilidade, baseando-se em parâmetros dados pelas características do meio físico, como a geologia, geomorfologia e pedologia. Ao valor dado à vulnerabilidade será computado o valor do uso e ocupação do solo, resultando no valor final do IST.

$\mathrm{Na}$ figura 3 é apresentado exemplo de Carta SAO para ambientes continentais (IST). A sensibilidade é dada por polígonos coloridos e os usos e ocupações do terreno são dados por polígonos hachurados. As informações sobre a biota e socioeconômica são fornecidas através de ícones. 


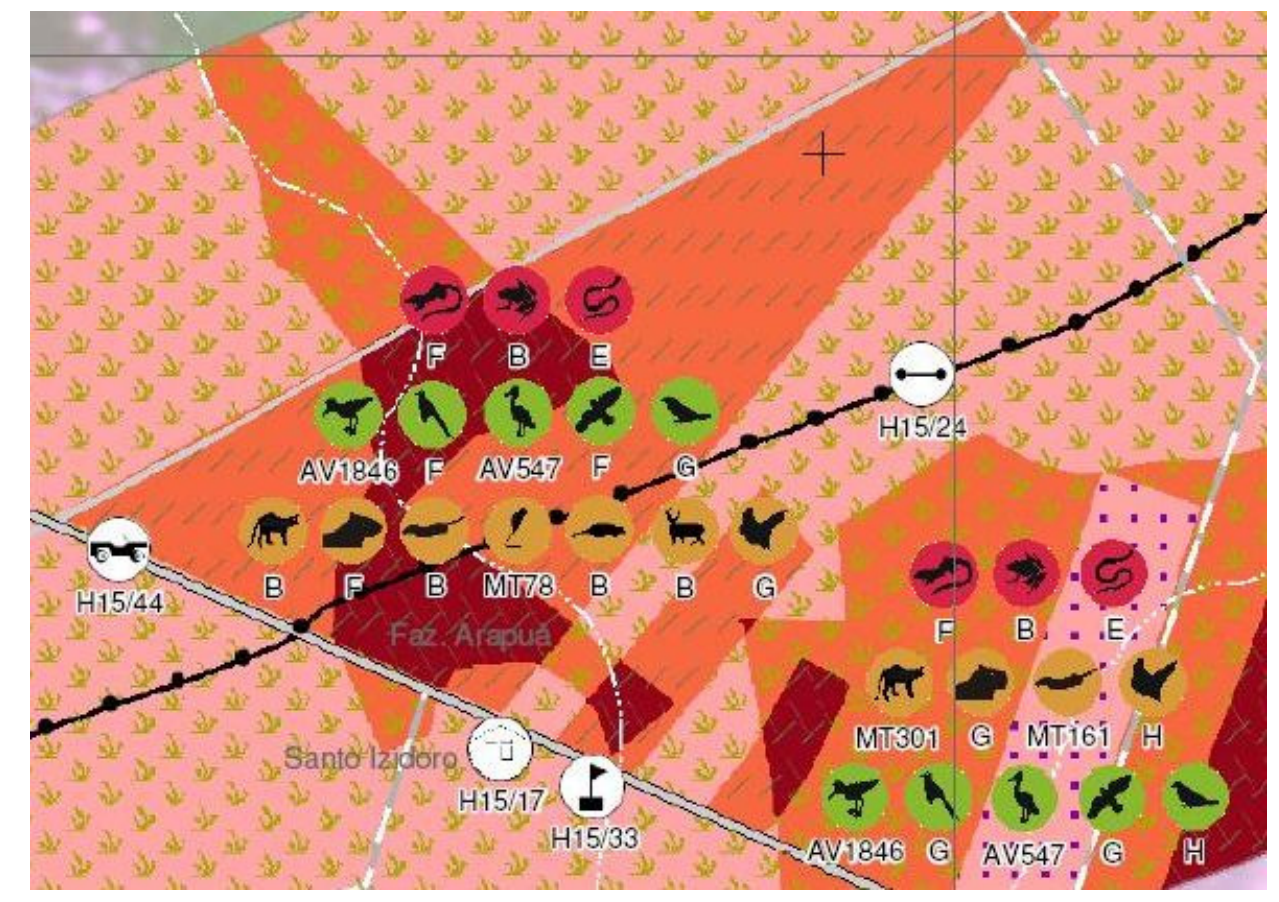

Figura 3 - Exemplo de Carta SAO para ambientes continentais (IST).

Ao se comparar as classificações de ambiente terrestre (IST) com o litorâneo (ISL), nota-se a utilização de número maior de variáveis e parâmetros analisados para o IST, resultando em complexa análise e interpolação de dados para a determinação de áreas sensíveis terrestres. No IST a sensibilidade é determinada pelas características do meio físico e do uso e ocupação do terreno e representados por polígonos (área); já no ISL a sensibilidade é determinada pelas características do meio físico, geomorfologia costeira, representados por segmentos de reta (linhas).

Na tabela 5 é apresentada a classificação proposta por Oliveira et. al. (2003), com os parâmetros de declividade, pedologia e geologia e respectiva paisagem utilizados para classificar a vulnerabilidade do meio. 
Tabela 5 - Classificação da vulnerabilidade a derrames de petróleo e seus derivados para áreas continentais brasileiras. Modificado de Oliveira et. al. (2003).

\begin{tabular}{|c|c|c|c|c|}
\hline IST & Declividade & Pedologia & Geologia & Paisagem \\
\hline 1 & $>30^{\circ}$ & $\begin{array}{c}\text { Solo pouco } \\
\text { desenvolvido } \\
\text { (neossolo, vertissolo e } \\
\text { secundariamente } \\
\text { cambissolo). }\end{array}$ & $\begin{array}{l}\text { Predominância de } \\
\text { rochas ígneas e } \\
\text { metamórficas } \\
\text { maciças. }\end{array}$ & $\begin{array}{l}\text { Relevo montanhoso, zonas } \\
\text { escarpadas, topografia juvenil } \\
\text { e pequenos caudais de } \\
\text { descarga rápida, encaixados } \\
\text { com afloramentos rochosos. }\end{array}$ \\
\hline 2 & $20^{\circ}-45^{\circ}$ & $\begin{array}{c}\text { Predomínio de } \\
\text { latossolo, cambissolo, } \\
\text { secundariamente, } \\
\text { neossolo e vertissolo. }\end{array}$ & $\begin{array}{l}\text { Predominância de } \\
\text { rochas ígneas e } \\
\text { metamórficas } \\
\text { maciças mais } \\
\text { estruturadas. }\end{array}$ & $\begin{array}{l}\text { Relevo montanhoso a colinoso, } \\
\text { zonas serranas, topografia } \\
\text { juvenil a madura com } \\
\text { drenagem menos densa, vales } \\
\text { com vertentes. Leitos pouco } \\
\text { acidentados, trechos arenosos, } \\
\text { com freqüentes corredeiras. }\end{array}$ \\
\hline 3 & $10^{\circ}-20^{\circ}$ & $\begin{array}{c}\text { Predomínio de } \\
\text { latossolo e cambissolo, } \\
\text { com ocorrência de } \\
\text { nitossolo, argissolo. }\end{array}$ & $\begin{array}{l}\text { Predominância de } \\
\text { rochas estruturadas, } \\
\text { metamórficas e } \\
\text { sedimentares } \\
\text { antigas. }\end{array}$ & $\begin{array}{l}\text { Relevo colinoso a subcolinoso. } \\
\text { zona de transição entre as } \\
\text { serras e planícies. Topografia } \\
\text { madura a senil, drenagem } \\
\text { diminuindo de densidade e } \\
\text { várzeas amplas nos talvegues. } \\
\text { Arenosos com descarga lenta e } \\
\text { margens regulares. }\end{array}$ \\
\hline 4 & $5^{0}-10^{\circ}$ & $\begin{array}{c}\text { Predomínio de } \\
\text { latossolo, planossolo e } \\
\text { nitossolo, com } \\
\text { ocorrência de } \\
\text { hidromórfico, argissolo, } \\
\text { espodossolo e } \\
\text { luvissolo. }\end{array}$ & $\begin{array}{l}\text { Predominância de } \\
\text { rochas sedimentares } \\
\text { e metamórficas } \\
\text { estruturadas } \\
\text { intemperizadas. }\end{array}$ & $\begin{array}{l}\text { Relevo subcolinoso a plano no } \\
\text { interflúvios de grandes rios de } \\
\text { planície. Topografia pré-senil a } \\
\text { senil, baixa densidade de } \\
\text { drenagem, amplas várzeas e } \\
\text { leitos aluviais. Grandes caudais } \\
\text { com lenta descarga e trechos } \\
\text { estagnados. }\end{array}$ \\
\hline 5 & $0^{\circ}-5^{\circ}$ & $\begin{array}{c}\text { Predomínio } \\
\text { hidromórfico, gleissolo, } \\
\text { organossolo e neossolo } \\
\text { arenoso. }\end{array}$ & $\begin{array}{l}\text { Predominância de } \\
\text { rochas sedimentares } \\
\text { mais recentes, pouco } \\
\text { consolidadas, como } \\
\text { areias, cascalhos, } \\
\text { lamitos. }\end{array}$ & $\begin{array}{l}\text { Relevo plano, várzeas, zonas } \\
\text { de confluência e estuarinas. } \\
\text { Topografia senil com drenagem } \\
\text { meandrante e anastomosada. } \\
\text { Leitos aluviais areno-argilosos. } \\
\text { Grandes caudais com lenta } \\
\text { descarga ou drenagem } \\
\text { estagnada formando áreas } \\
\text { inundadas ou com influência } \\
\text { das marés. }\end{array}$ \\
\hline $\begin{array}{c}5 c \\
\text { (carste) }\end{array}$ & $0^{\circ}-90^{\circ}$ & $\begin{array}{l}\text { Solos com caráter } \\
\text { carbonático. }\end{array}$ & Rochas carbonáticas. & Relevo cárstico. \\
\hline
\end{tabular}

Tanto no ISL com o IST, as informações sobre o meio biótico e socioeconômico são representadas por ícones não quantificáveis, permitindo a interpretação no momento do derramamento, de acordo com as características locais. A sensibilidade de um trecho da linha de costa classificada como ISL - 5 pode, por exemplo, ter sua sensibilidade real aumentada se houver alguma operação de contingência que coincida com o período de desova de tartarugas, ou se o local for ocupado por comunidade de pescadores, por exemplo. 
No IST, o sítio mapeado que apresentar características do meio físico com valores baixos, terá o valor de sensibilidade final consideravelmente aumentado se 0 local for ocupado por área urbana ou se for ocupado por alguma floresta ombrófila, por exemplo. Ou mesmo, um sítio com valores altos de meio físico pode diminuir de valor, caso seja uma área de mineração.

Os aspectos conceituais aqui abordados buscam auxiliar a compreensão de terminologias e processos de interpretação do meio físico, permitindo melhor entendimento da leitura e discussão sobre os métodos e propostas apresentadas neste trabalho. Entretanto, não substituem a leitura de normas oficiais para elaboração da Carta SAO.

São também discutidos temas como a utilização e entendimento dos conceitos de sensibilidade e vulnerabilidade ambiental. Seguido da apresentação dos parâmetros utilizados para a determinação da sensibilidade ambiental. Estes parâmetros foram divididos em dois grupos distintos: relevo e declividade e textura sedimentar, por serem entendidos como os principais elementos que controlam o comportamento do óleo no terreno, como descritos por Oliveira et. al. (2003), ou seja, trajetória, espalhamento e permanência. 


\section{Aspectos conceituais dos parâmetros propostos para a elaboração de Cartas Sensibilidade para Ambientes Continentais}

\subsection{Geomorfologia e declividade}

O relevo e a declividade têm papel importante na trajetória do óleo sobre o terreno, onde a geomorfologia é considerada como parâmetro fundamental no entendimento sobre o espalhamento do poluente em áreas continentais (Benito et. al. 2001). A determinação e análise geomorfológica da bacia hidrográfica vulnerável a um derramamento de óleo são os procedimentos iniciais para o entendimento do comportamento da mancha no terreno (Hayes et. al. 1994).

Demais informações referentes às condições geológicas do ambiente, tais como presença de planícies de inundação, meandros abandonados, áreas alagadas, barras e praias de areia, declividade do terreno e a rede de drenagem são parâmetros importantes a serem analisados no desenvolvimento deste tipo de mapeamento.

A quantificação dos dados de declividade foi obtida a partir de um MDT (Modelo Digital de Terreno), sendo este indexado e relacionado à classificação dos graus de declividades, divididos em classes correspondentes às existentes do Índice de Sensibilidade Terrestre (IST), de Oliveira et al. (2003).

A classificação de declividade baseou-se em estudos de estabilidade de talude e de erosão, mas foi considerada de forma invertida. Declividade com grande porcentagem (por exemplo, 30\%) é considerada ruim para a estabilidade do terreno e favorável à erosão, mas no caso do derramamento de óleo é considerado favorável por resultar baixo tempo de residência do óleo no terreno. Neste trabalho 
foram considerados os valores inversos da escala de classes clinográficas proposta por Leal (1995), apresentado pela tabela 7.

Tabela 6 - Classes clinográficas e descrição, segundo proposta de Leal (1995).

\begin{tabular}{|c|c|}
\hline Classes & Descrição do ambiente \\
\hline$<5 \%$ & $\begin{array}{c}\text { Áreas quase planas, adequadas à urbanização (no caso de } \\
\text { vertentes e/ou topos retilíneos), ou inadequadas (no caso de } \\
\text { planícies fluviais, pelos riscos de inundação) }\end{array}$ \\
\hline $\begin{array}{c}5 \% \text { a } \\
10 \%\end{array}$ & $\begin{array}{c}\text { Áreas com moderada susceptibilidade à erosão, com poucas } \\
\text { exigências para sua urbanização. }\end{array}$ \\
\hline $\begin{array}{c}10 \% \text { a } \\
20 \%\end{array}$ & $\begin{array}{c}\text { Áreas com forte susceptibilidade à erosão necessitando de } \\
\text { adequado manejo para sua urbanização. }\end{array}$ \\
\hline $\begin{array}{c}20 \% \text { a } \\
30 \%\end{array}$ & $\begin{array}{c}\text { Áreas com escoamento superficial muito rápido e muito forte } \\
\text { susceptibilidade à erosão a urbanização deve ser controlada com } \\
\text { medidas especiais. }\end{array}$ \\
\hline $30 \%$ & $\begin{array}{c}\text { Áreas extremamente susceptíveis à erosão urbanização com } \\
\text { severas restrições, segundo a Lei 6.766/79. }\end{array}$ \\
\hline
\end{tabular}

A movimentação do óleo em áreas continentais dependerá das características físicas da bacia hidrográfica da área de estudo. Ao se comparar dois tipos distintos de relevo, suave e acidentado, pode-se compreender melhor o comportamento do óleo. Em relevo suave, o material derramado apresentará maior potencial de contaminação do solo, por apresentar pequena movimentação e, portanto, maior probabilidade de infiltração. Em relevos acidentados, o potencial de contaminação será menor, devido a maior movimentação do óleo pelo terreno, afetando maiores áreas e em distâncias maiores, mas com menor probabilidade de infiltração no sedimento. 


\subsection{Textura Sedimentar (Porosidade x Permeabilidade)}

No entendimento do espalhamento de óleo pelo terreno, ao se considerar um vazamento sobre área exposta, o óleo tenderá a escorrer até atingir um canal de drenagem mais próximo, transformando este canal em "vetor de espalhamento" pela rede de drenagem até atingir a drenagem de maior ordem. Assim, quanto mais complexa for a rede de drenagem, ou seja, quanto maior o número de canais distributários, maior será o espalhamento do poluente pela bacia.

Devem-se considerar alguns aspectos do espalhamento do óleo pelo terreno, como o tempo de retenção de óleo no sedimento e a sua capacidade de retenção. O tempo é determinado pela declividade, onde um terreno de alta declividade resultará em tempo de retenção menor e um terreno de baixa declividade, um tempo maior.

Alguns parâmetros texturais dos sedimentos determinam a infiltração, assim, quanto maior o tempo de permanência do óleo em um sítio, maior será a sua interação com meio, maior será o dano causado ao ambiente e mais difícil será sua recuperação. Desta forma, devem-se observar os parâmetros sedimentares que determinam as características como porosidade e permeabilidade.

A porosidade e permeabilidade do sedimento e de rochas sedimentares estão associadas às suas características texturais. Os parâmetros texturais que influenciam na porosidade e permeabilidade são o tamanho (granulometria), seleção, forma (esfericidade) e arredondamento, acrescido do padrão de empacotamento (trama).

A permeabilidade diminui com a diminuição do tamanho dos grãos, pois apesar da diminuição dos diâmetros das partículas, há aumento considerável da capilaridade, desta forma, areias grossas tendem a ser mais permeáveis do que areias finas (Selley, 1998). 
A estrutura do sedimento influencia na direção e tempo de viagem dos fluxos de água. Em terrenos homogêneos, a porosidade total tende a decrescer com a profundidade, acompanhada pelo aumento da densidade aparente. A existência de descontinuidades pode aumentar a porosidade. Assim, três forças devem ser consideradas na infiltração em meio poroso: a declividade, a atração capilar e a força gravitacional. A força gravitacional direciona a água verticalmente no perfil do terreno, a força capilar impulsiona a água em todas as direções, especialmente para cima. A água, ao percolar o sedimento, sofre resistência da força capilar, que aumenta à medida que os poros diminuem de diâmetro.

Atividades biológicas, associadas às raízes mortas e animais escavadores têm papel importante no aumento da porosidade do solo, as raízes têm importância na estruturação do solo ampliando a capacidade de transmissão de água. E seu adensamento na superfície do terreno florestado permite a injeção de água nos solos. Poros maiores, como os das escavações de atividades biológicas, tornam a força de capilaridade nula. Condição da cobertura do solo: cobertura vegetal tende a aumentar a capacidade de infiltração; solos cobertos por florestas apresentam maiores valores de infiltração (Guerra e Cunha, 1994).

A porosidade primária se forma na deposição do sedimento e a secundária após a sua deposição. Pode-se dividir a porosidade em dois tipos: a intergranular e a intragranular. A porosidade intergranular é encontrada na maioria dos sedimentos, principalmente em rochas arenosas. Na área de estudo foram mapeadas rochas arenosas pertencentes à Formação Botucatu, onde este tipo de porosidade é predominante. A porosidade intragranular ocorre no interior do próprio grão, geralmente de feldspatos. Em rochas fraturadas, a porosidade secundária é 
importante, não por aumentar a capacidade de armazenamento de óleo, mas por aumentar a sua permeabilidade (Selley, 1998).

Beard e Weyl (1973) realizaram ensaios em areias inconsolidadas, resultando em dois valores principais de porosidade para dois arranjos distintos de areias. As areias extremamente bem selecionadas chegaram a apresentar porosidades de até $42,4 \%$, enquanto que areias com seleção muito pobre chegaram a valores de até 27,9\%. Nestes ensaios, a porosidade mostrou-se diretamente influenciada pela granodecrescência e pelo empacotamento dos grãos. Nas amostras secas e pouco compactadas a porosidade aumentou com a diminuição dos grãos e nas amostras úmidas e compactadas a porosidade permaneceu indiferente à granulometria. Assim, pode-se concluir que a porosidade é independente do tamanho do grão, mas varia de acordo com a sua seleção.

No gráfico da figura 4 é apresentada a relação experimental entre a porosidade e permeabilidade de areias inconsolidadas proposta por Beard e Weyl (1973) e modificado por Nagtegaal (1978), em relação ao comportamento dos parâmetros de tamanho e seleção de grãos. 


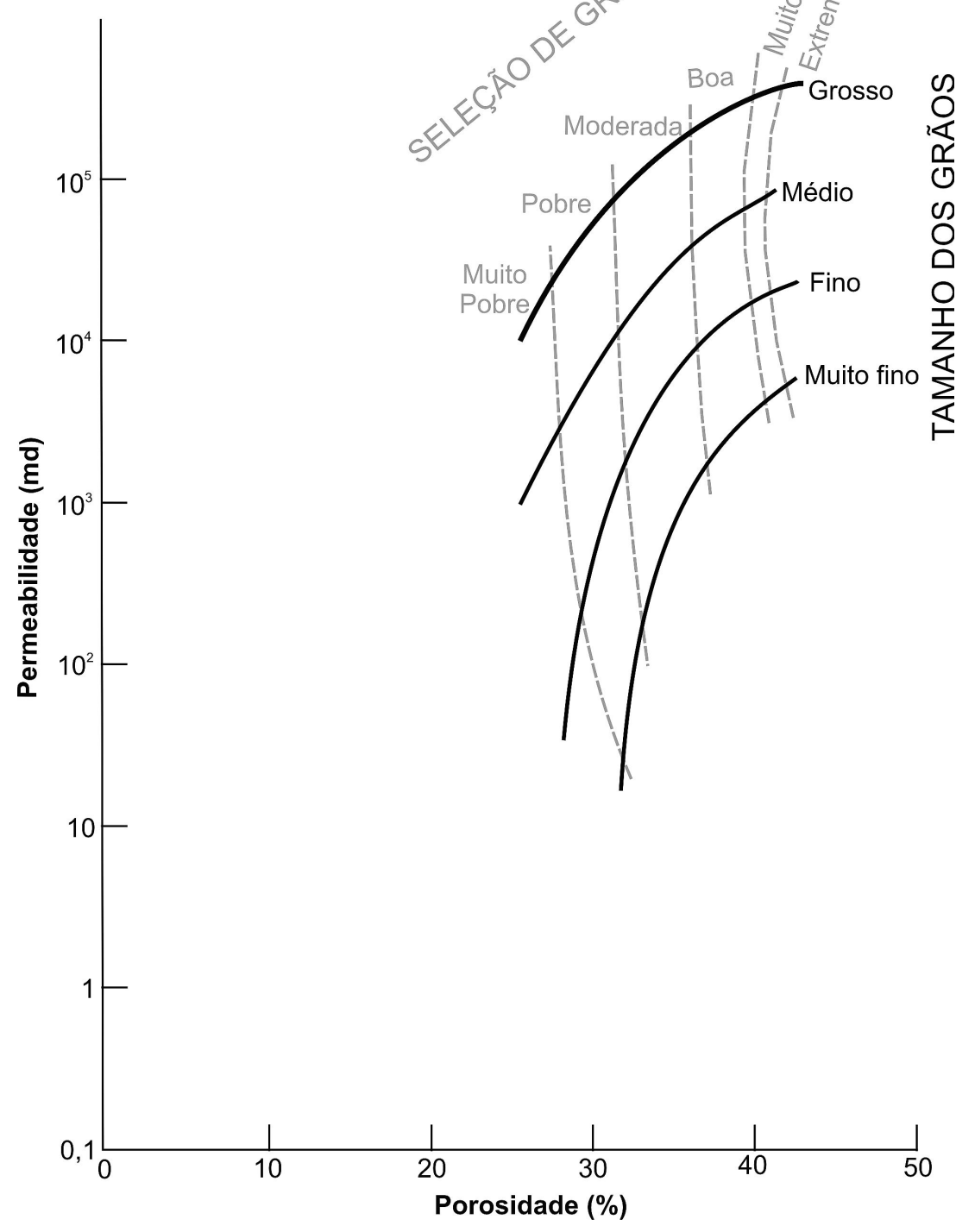

Figura 4 - Porosidade x Permeabilidade, em função do tamanho e seleção de grãos de areia. Modificado de Nagtegaal (1978).

No gráfico da figura 4, não são contempladas amostras com a presença de mais de $5 \%$ de argila, sendo aplicado para rochas predominantemente arenosas. A presença de mais de $5 \%$ de material de granulometria fina, como argila e siltes, resultam na diminuição de porosidade e conseqüente diminuição também da permeabilidade do terreno.

Terrenos que apresentam pobre seleção de grãos permitem que os interstícios intergranulares sejam preenchidos por argilas e silte, obstruindo os poros e conseqüentemente reduzindo a sua porosidade e permeabilidade (Selley, 1998 e 
Florez e Marva, 2003). Já a permeabilidade de areias inconsolidadas diminui enquanto os tamanhos dos grãos tornam-se mais finos e a seleção mais pobre, (Beard e Weyl, 1973).

$\mathrm{Na}$ figura 5 são apresentadas as classes de seleção de grãos e desenhos esquemáticos de sedimentos. Os valores desta tabela foram utilizados para a determinação das classes de sensibilidade para ambientes continentais.
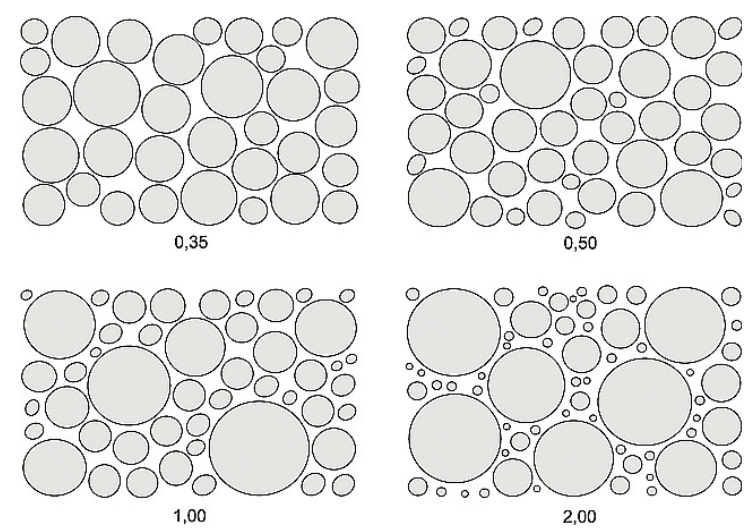

\begin{tabular}{|c|c|}
\hline $\begin{array}{c}\boldsymbol{\sigma} \text { do } \\
\text { diâmetro } \boldsymbol{\Phi}\end{array}$ & Seleção \\
\hline 4,00 & Extremamente pobre \\
\hline 2,00 & Muito pobre \\
\hline 1,00 & Pobre \\
\hline 0,50 & Moderada boa \\
\hline 0,35 & Boa \\
\hline 0,00 & Muito boa \\
\hline 0,71 & Moderada \\
\hline
\end{tabular}

Figura 5 - Classes de seleção de grãos. Modificado de Folk (1968).

A esfericidade e arredondamento são parâmetros da forma dos grãos a serem considerados. $\mathrm{O}$ arredondamento corresponde ao grau de angulosidade da partícula e a esfericidade o grau de aproximação da forma de uma partícula a uma esfera. Segundo Fraser, (1935) apud Selley, (1998), a porosidade pode diminuir com o aumento da esfericidade devido à possibilidade do empacotamento dos grãos poder ser mais compactado do que aquelas com esfericidade menor (Selley, 1998). Grãos bem arredondados e com alta esfericidade devem empacotar com o espaço mínimo 
de poros, mas com o aumento da angulosidade dos grãos, o espaço do poro tende a aumentar (Beard e Weyl, 1973).

A figura 6 apresenta as classes de arredondamento e esfericidade de grãos de areia na escala phi $(\Phi)$, definidas por Pettijohn et. al. (1987). Estas classes auxiliam na observação de campo da geometria dos sedimentos.

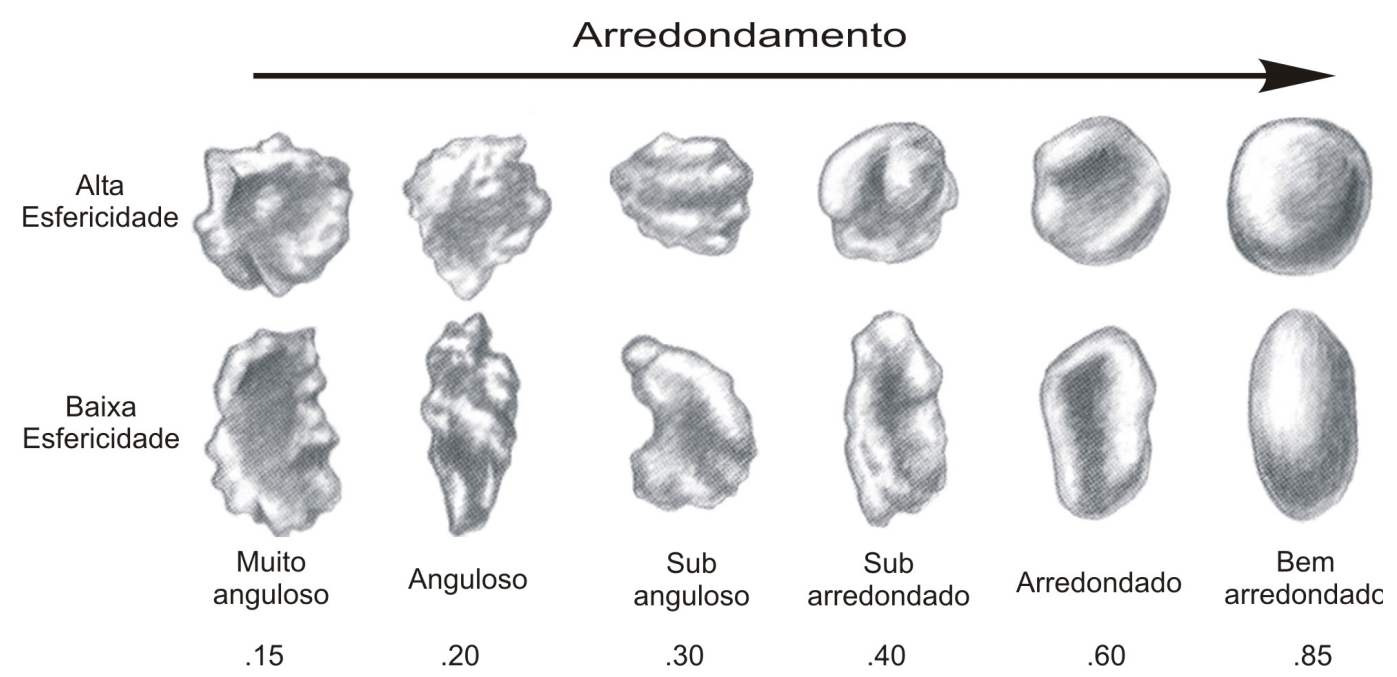

Figura 6 - Classes de arredondamento e esfericidade de grãos de areia, modificado de Powers (1953).

Os efeitos da forma e arredondamento do grão para a permeabilidade e porosidade do sedimento são considerados de importância secundária se comparado ao tamanho e seleção dos grãos. O efeito mais provável da baixa esfericidade e da alta angulosidade é aumentar a porosidade e permeabilidade de areias inconsolidadas (Beard e Weyl, 1973).

A trama do sedimento e como seus grãos estão empacotados e orientados estão intimamente relacionados às suas características de porosidade e de permeabilidade. O arranjo de esferas uniformes tem a geometria de um arranjo cúbico mais frouxo, apresentando cerca de $48 \%$ de porosidade, e o arranjo romboédrico, mais fechado, com $26 \%$ de porosidade (Selley, 1998). 


\subsection{Sensibilidade $x$ Vulnerabilidade.}

A irregularidade na utilização e mesmo as traduções equivocadas sobre as definições de vulnerabilidade e de sensibilidade de um ambiente resultam em incertezas no entendimento, na interpretação e elaboração de planos de emergência e de contingência ao derramamento de óleo.

Em Gundlach e Hayes (1978), o meio é classificado de acordo com a sua vulnerabilidade. Já em Hayes et. al. (1994), API e NOAA (1994), IMO e IPIECA (1996), NOAA (1997) e MMA (2002), o meio é classificado de acordo com a sua sensibilidade. Nestes relatórios e normas observa-se que a utilização da palavra sensibilidade e vulnerabilidade se confundem e são utilizadas para descrever a mesma situação, ou seja, o comportamento de determinado meio frente ao óleo.

No trabalho apresentado por Oliveira et. al. (2003), primeiro é determinada a vulnerabilidade da área, pela aplicação de cálculo da média ponderada de valores dados aos parâmetros geológico, pedológico e geomorfológico. Depois de definida a vulnerabilidade, é determinada a sensibilidade com base no valor obtido para vulnerabilidade acrescido do parâmetro de uso e ocupação do solo. A sensibilidade é o resultado da aplicação da mesma fórmula para obtenção do valor da vulnerabilidade, porém acrescido dos valores ponderados do uso e ocupação do terreno, ou seja, a sensibilidade é dada pela combinação dos valores da vulnerabilidade ao uso e ocupação do solo.

No método proposto por Oliveira et. al. (2003), são conferidas notas de 1 a 10 para cada categoria e conseqüente peso ponderado para cada classe, sendo a geologia $10 \%$, declividade $15 \%$, pedologia $15 \%$ e uso e ocupação do terreno $60 \%$. Estes pesos podem variar de acordo com as características físicas regionais, 
reduzindo-se o peso do uso e ocupação do terreno e aumentando proporcionalmente os outros.

Uma análise sobre a distinção entre vulnerabilidade e sensibilidade permite concluir que os dois termos devam ser empregados de formas distintas. Uma área pode ser classificada em diferentes níveis de sensibilidade, já quanto à vulnerabilidade, não é possível estabelecer essa gradação, se a área é ou não é vulnerável.

\subsection{Derramamento de óleo em áreas continentais}

O óleo, quando exposto ao meio, sofre alterações em suas propriedades físicoquímicas, gerando alterações que podem resultar no aumento da quantidade de resíduos.

De maneira geral, sem considerar o tipo do meio, o óleo se comportará de maneira similar quando exposto à força dos elementos naturais. Grande parte da literatura disponível sobre o tema, privilegia estudos sobre o óleo derramado no mar. Relatórios realizados pela IMO e ITOPF apresentam dados sobre o destino do óleo quando exposto ao meio oceânico, frente à quase total ausência de estudos em meio continental.

Ao considerar vazamentos ocorridos em ambiente oceânico e o comportamento das distintas classes de hidrocarbonetos, é possível observar o aumento da persistência do produto mais pesado em razão do tempo de exposição, acarretando interação maior com o meio.

Na figura 7 observa-se a relação entre a persistência do óleo ao meio ambiente marinho, onde o aumento do volume de óleo pelo efeito de emulsão água-óleo, na superfície da água, devido a sua interação com o meio, pode causar aumento de 
seu volume final se comparado ao valor inicial derramado. Esta relação pode ser utilizada em ambientes continentais, com as devidas adequações, considerando-se que a maioria das feições estão relacionadas a ambientes de menor energia envolvida e ausência de particularidades relativas à linha de costa e marés.

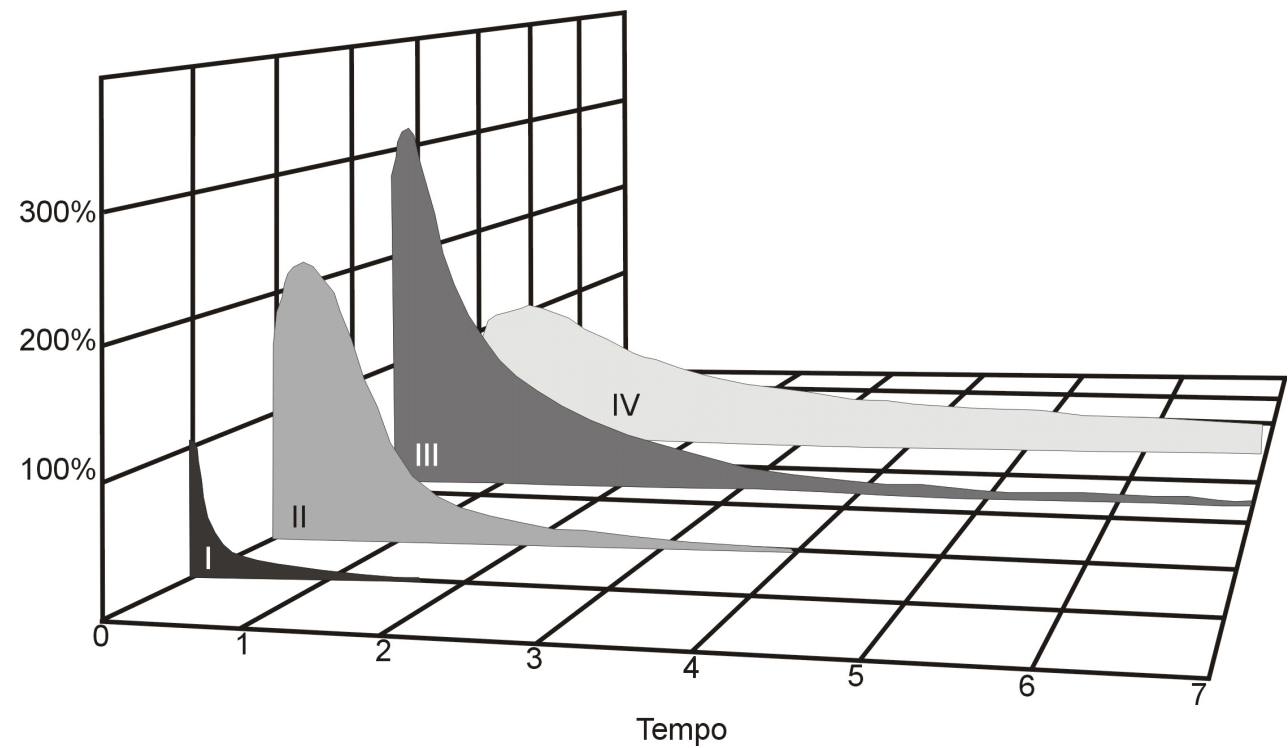

Figura 7 - Persistência do óleo ao meio x dias de exposição ao ambiente. Sendo: I gasolina, II - diesel e óleos leves, III - óleos e produtos intermediários e IV - óleos e produtos pesados e o tempo, dado em dias. Modificado de ITOPF, 1996.

O ambiente marinho pode apresentar papel importante na atenuação natural do óleo derramado; essas ações naturais podem diminuir o seu impacto, sendo este processo denominado intemperismo. Na figura 8 são ilustrados os principais processos que atuam no intemperismo do óleo, em meio aquoso. 


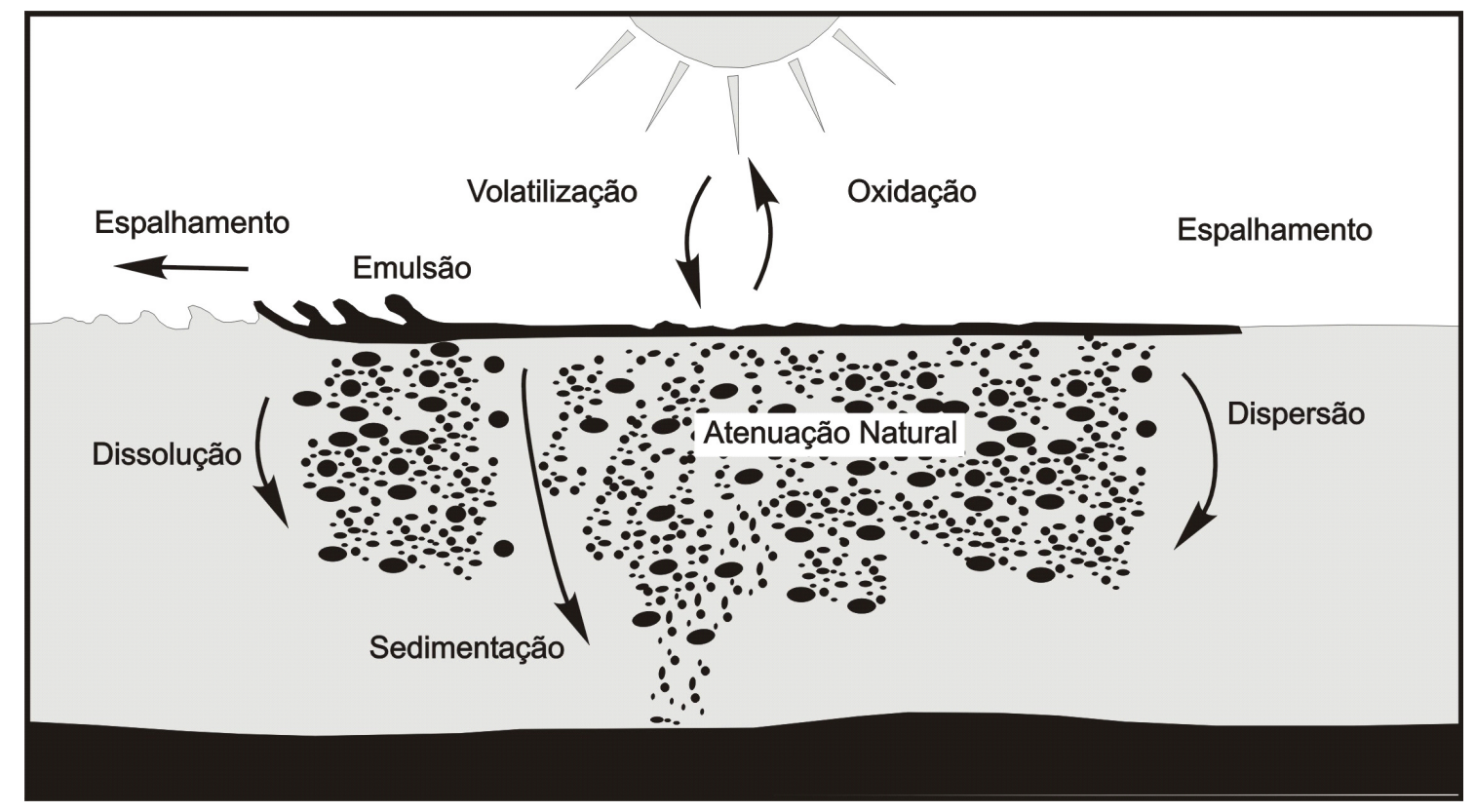

Figura 8 - llustração das principais processos de intemperismo, em meio aquoso. Modificado de ITOPF (1996).

Ambientes continentais (exceto em grandes rios caudalosos) tendem a apresentar energia menor do que a linha de costa, exceto em regiões estuarinas. A menor energia implica em menor intemperismo do óleo e, conseqüentemente, menor atenuação natural, o que acentua o problema dos derramamentos em ambientes terrestres e fluviais.

Ao comparar o comportamento do óleo derramado em ambientes continentais e oceânicos, notam-se grandes diferenças tanto no seu espalhamento, infiltração e degradação, como nas prioridades de proteção de locais que possam ser atingidos pelo produto, resultando em danos ambientais e socioeconômicos de formas e maneiras diversas.

Em ambiente continental o espalhamento é menor, se comparado ao oceânico, mesmo que atinja grandes cursos de água a capacidade de atenuação natural por ondas e zonas de arrebentação será menor. Quanto maior o tempo de espalhamento, maior será a área impactada e maiores os danos ambientais. No figura 9 é apresentada comparação entre o comportamento do óleo nos dois 
ambientes. Os custos, impactos ambientais e dificuldade de resposta são maiores e a precisão de modelagem, proteção e recuperação ambiental são menores em meios que apresentam maior energia, como um grande rio ou o mar, em função de tempo e movimentação do óleo.

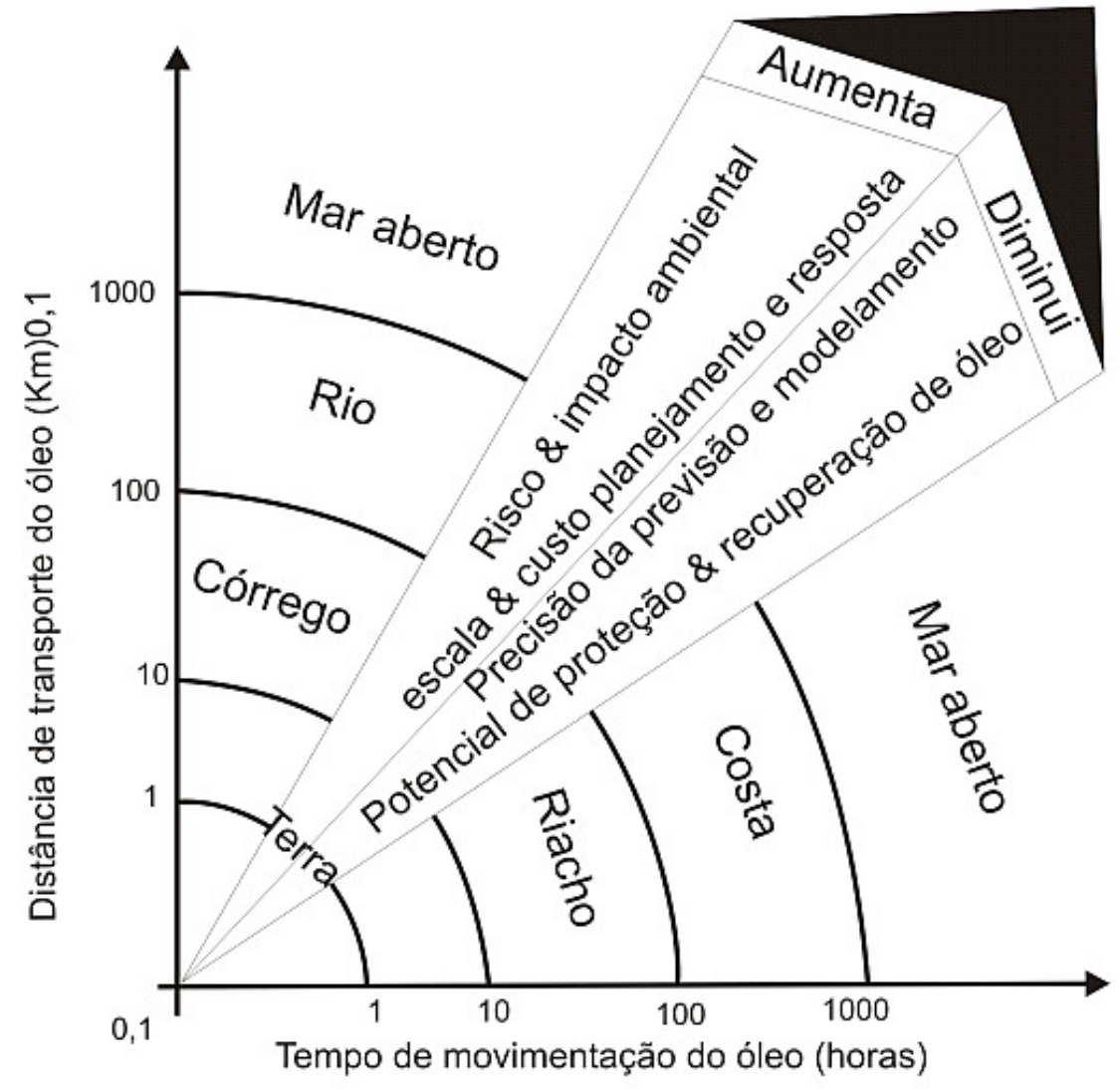

Figura 9 - Derrame Terrestre x Costeiro. Modificado de Owens (2002).

Owens (2002) considerou como "vantagens" de um derrame em continente a facilidade de previsão da trajetória do óleo e seus efeitos, áreas impactadas menores e maior potencial de recuperação do óleo. E como "desvantagens" a baixa capacidade de intemperismo e atenuação natural, grande potencial de causar danos a recursos naturais e socioeconômicos e maior possibilidade de se elaborar um plano de contingência específico. 
Acidentes em áreas continentais não são menos danosos ao meio ambiente do que os em áreas oceânicas. Derramamentos em áreas continentais ocorrem também em grande freqüência e geram tantos prejuízos quanto no mar. Há grande quantidade de estruturas humanas como plantações, criações, poços de água, tomadas de água (para uso industrial, agropecuário ou para consumo humano), áreas de lazer e concentrações urbanas (de qualquer tipo e tamanho) estão localizadas em ambientes continentais. Sendo assim, deve-se ter atenção na quantidade de produto infiltrado no solo, principal fator de contaminação do aqüífero e da zona vadosa.

Em relatório publicado pela CONCAWE (Conservation of Clean Air and Water in Europe) foi estimado que o grau de infiltração do óleo no solo é determinado por três elementos principais, ou seja, pelas características do terreno, posição do nível freático e pelo volume e tipo de óleo derramado. Óleo de baixa viscosidade infiltrará mais rapidamente em solos porosos e secos, como areia grossa, diminuindo 0 espalhamento superficial.

O óleo ao infiltrar no solo, se movimentará sob influência da gravidade e da capilaridade. Quando o óleo se move, deixa o solo saturado com material residual, denominado como capacidade de retenção do solo (Fussel et. al., 1981).

Na figura 10 são apresentadas ilustração dos três tipos básicos de plumas de infiltração, determinadas pela composição do pacote sedimentar. A, terreno homogêneo, $B$, terreno heterogêneo e $C$, terreno heterogêneo apresentando estratos com diferentes classes granulométricas. 

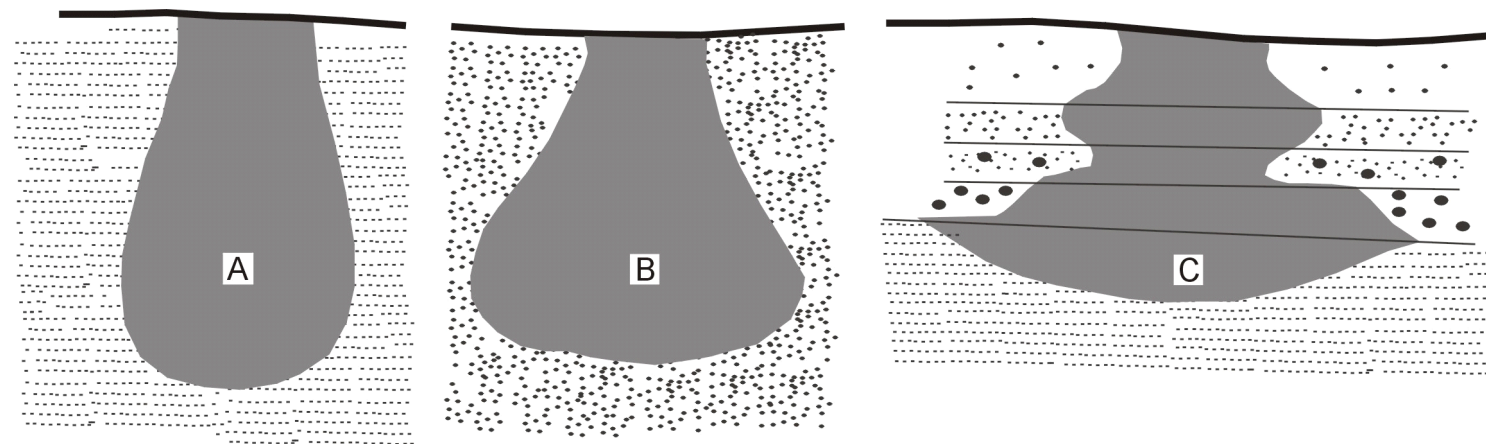

Figura 10 - llustração dos três tipos básicos de plumas de infiltração. Modificado de Fussel et. al. (1981).

Locais onde o nível freático aflora, ou é sub-superficial, bem como solos argilosos, resistirão à infiltração. Neste caso, mais especificamente com óleos mais viscosos, haverá espalhamento maior da área atingida. Óleos muito viscosos, como aqueles que se resfriam ao contato com o meio, podem formar uma massa de piche no terreno, com espalhamento limitado pela alta viscosidade.

Alguns fatores podem influenciar na porosidade do terreno, como em locais com atividades agropecuárias, onde se encontram estruturas biogênicas, como orifícios escavados por minhocas, porém esses podem ter a infiltração impedida se estiverem encharcados. A presença de argilas não significa diretamente que o substrato seja impermeável, pois podem apresentar alta porosidade, dependendo da capacidade de troca catiônica do solo, mas geralmente tendem a apresentar baixa permeabilidade.

A taxa de infiltração do óleo no sedimento depende do tipo de óleo e da granulometria. Um local formado por cascalho grosso, atingido por um óleo de baixa viscosidade, resulta numa taxa maior de infiltração. No início do vazamento a pressão exercida pela massa de óleo gera uma pressão para o sub-solo. Essa pressão diminui quando a taxa de espalhamento diminui a percolação pode durar por vários dias e na prática, óleos muito viscosos (pesados e crus) tendem a apresentar baixa infiltração. 
Em sedimentos homogêneos (Figura 10A), sem estratificações ou horizontes diferenciados e pequenas variações no tamanho e distribuição dos poros, a pluma apresentará forma de gota, predominando a componente de vertical regida pela força da gravidade.

A Figura 10B apresenta a pluma de contaminação em forma de lâmpada, indicando a baixa homogeneidade dos poros, gerando menor permeabilidade e porosidade, logo, diminuindo a infiltração do produto no sedimento. A componente vertical será menor, enquanto a componente horizontal terá maior influência, dada pela força de capilaridade.

Em terrenos com grande heterogeneidade sedimentar (Figura 10C), a infiltração do óleo no sedimento apresentará grande irregularidade na pluma. A existência de camadas com distintas granulometrias e, conseqüentemente, distintas porosidades e permeabilidades, resultarão em deslocamentos irregulares das componentes verticais e horizontais.

Assim, a migração da pluma no subsolo se desenvolverá pela sucessiva impregnação de grandes áreas, num estrato permeável, sendo que a infiltração principal será dada pela resultante entre os vetores da gravidade e da declividade do terreno. Em um estrato menos permeável, a componente de capilaridade resultará em maior penetração horizontal. A heterogeneidade do sedimento dará grande influência no modo e na forma da pluma de infiltração do óleo no meio.

O valor máximo de infiltração no sedimento ocorre caso haja o acúmulo do produto em poças ou piscinas, na superfície do terreno. Esta concentração aumenta o valor da pressão de carga do óleo sobre o terreno, aumentando a pressão e a taxa de infiltração. Entretanto, em casos especiais, onde há rochas fraturadas ou a presença de uma camada sedimentar impermeável, ou mesmo a presença do nível 
d'água, há alteração nos processos de infiltração e de movimentação do óleo pelo horizonte vadoso.

\subsection{Comportamento dos diferentes hidrocarbonetos no ambiente}

Os derivados do petróleo apresentam amplo espectro de produtos com distintas características que devem ser consideradas no desenvolvimento de técnicas e estratégias de resposta, limpeza e contenção do produto derramado. As características mais importantes a serem observadas nestes produtos são dadas pela sua volatilidade, grau API e viscosidade (Hayes et. al. 1994).

A volatilidade é relativa aos óleos que evaporam rapidamente após serem liberados no meio. Podem causar grandes impactos para a equipe de resposta, além da possibilidade de explosão, assim a opção mais segura, normalmente, é a de deixar evaporar o produto antes de serem iniciados os trabalhos, uma vez que óleos de alta volatilidade evaporam em um ou dois dias.

O grau API trata-se de uma classificação dada pelo American Petroleum Institute a fim de determinar a gravidade especifica de cada hidrocarboneto. Assim, óleos com valores de gravidade especifica maior que 1.00, ou API menor que 10, afundará na água. Entretanto aqueles com valores próximos a 0.95 ou maior apresentam um risco de afundar e se misturar com sedimentos.

A viscosidade de cada tipo de hidrocarboneto implica na taxa de espalhamento do óleo em superfície aquosa e a infiltração no substrato. Óleos de baixa viscosidade se espalham rapidamente em películas finas e iridescentes, resultando em aumento da área de superfície. Há alguns óleos que não se espalham se entram em contato com água fria, como o caso de asfalto ou óleos de alta viscosidade. Emulsões, ou "mousse" como também é denominado, podem conter cerca de até 
$80 \%$ de água na sua composição, tornando-se muito mais viscosas do que originalmente. Gasolina não emulsifica, mas o diesel pode fazê-lo e rapidamente. Quando uma emulsificação se forma, o óleo se modifica em aparência e viscosidade, e adquire aumento volumétrico de cerca cinco vezes do seu volume inicial.

Assim, a partir dos parâmetros acima apresentados, pode-se classificar os hidrocarbonetos em quatro grupos distintos: produtos de gasolina e óleos crus leves, médios e pesados.

Os produtos de gasolina são muito voláteis e altamente inflamáveis, com altas taxas de evaporação e resultam em pouco ou nenhum resíduo. A baixa viscosidade implica em rápido espalhamento e infiltração, decorrência da baixa gravidade específica, de menos 0,80 . Apresenta alta toxicidade ao meio e não emulsifica e não é adesivo.

Os óleos crus leves apresentam volatilidade moderada, deixam resíduos, após a evaporação, viscosidade moderada a baixa, espalhamento relativamente menor que o da gasolina, e gravidade específica de 0,80 a 0,85 e API de 35 a 45, podendo infiltrar no substrato. A toxicidade ao meio é moderada a alta, podendo formar emulsificações estáveis e derramamentos frescos não são adesivos.

Os óleos crus de grau médio e produtos intermediários são de volatilidade moderada, geralmente, mais de um terço evapora nas primeiras 24 horas. Apresenta moderada a alta viscosidade, gravidade específica de 0,85 a 0,95 e API variando de 17,5 a 35. A toxicidade pode ser alta, o que depende de sua fração leve, podendo formar emulsões estáveis e apresentam características de infiltração e penetração diferente para cada tipo de produto. 
Já os óleos pesados e produtos residuais são relativamente pouco voláteis, e conseqüentemente deixam resíduos, são viscosos a semi-sólidos, com gravidade especifica de 0,95 a 1,00 e API variando entre 10 a 17,5. A toxicidade é baixa se comparado a outros óleos, podem formar emulsões estáveis, com baixa infiltração e penetração no substrato, mas é adesivo. 


\section{Aplicação dos parâmetros texturais na elaboração da Carta SAO da Bacia do}

Rio do Tamanduá - Cravinhos e São Simão (SP)

Para aplicação pratica dos parâmetros e métodos propostos, foi escolhida a área da Bacia do Rio Tamanduá, nos municípios de Cravinhos e São Simão, Estado de São Paulo, em função de ser uma área interceptada por duto de transporte de hidrocarbonetos e, também, por ser a área de exposição dos arenitos da Formação Botucatu, sendo esses a rocha-reservatório do Sistema Aqüífero Guarani.

\subsection{Localização da área}

A área de estudo localiza-se entre as coordenadas $21^{\circ} 08^{\prime} \mathrm{S}, 47^{\circ} 38^{\prime} \mathrm{W}$ e $21^{\circ}$ 30 S, 47ํㅜ 36' W, na região metropolitana de Ribeirão Preto, nordeste do Estado de São Paulo, próximo às cidades de Cravinhos, São Simão, Distrito de Bento Quirino, e Serra Azul. Corresponde à área de influência das bacias dos rios Mogi - Mirim e Pardo, e à sub-bacia do Ribeirão do Tamanduá.

O acesso principal à área se dá pela Rodovia Anhanguera (SP-330), por vias estaduais asfaltas SP-253, 271 e 333 e por estradas secundárias de terra e vias temporárias de canaviais (Figura 11). 


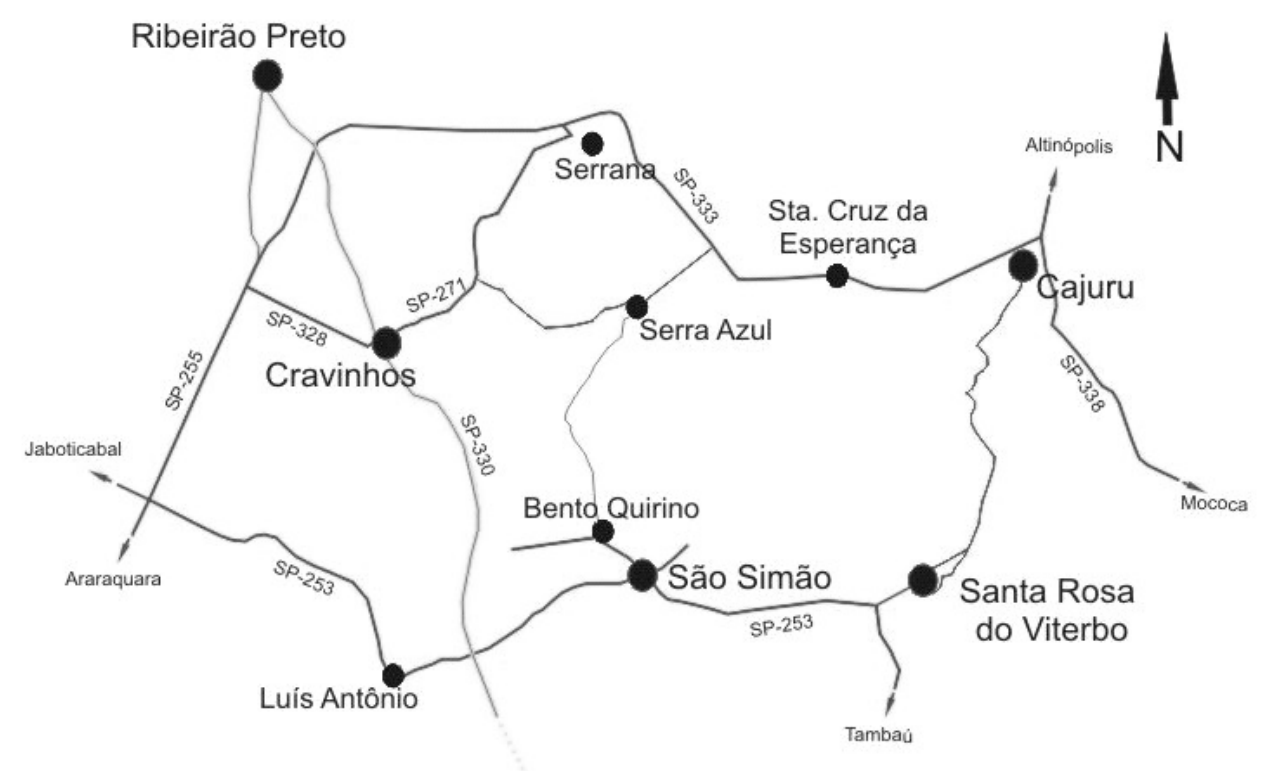

São Paulo

DER-SP/2003

Figura 11 - Croqui dos acessos principais à área de estudo. Modificado de DER-SP (2003).

A área é, em sua grande maioria, ocupada por fazendas com cultivo temporário de cana-de-açúcar e permanente de cítricos e café, entre outros. Parte da várzea do Ribeirão do Tamanduá, próximo à via férrea, é ocupada por assentamento rural, composto por pequenas propriedades e chácaras.

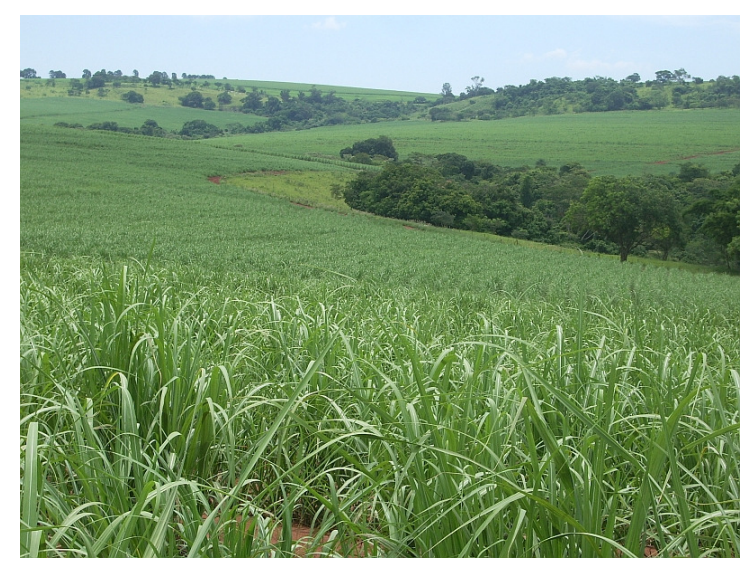

Figura 12 - Ocupação da área de estudo. Eminentemente por canaviais

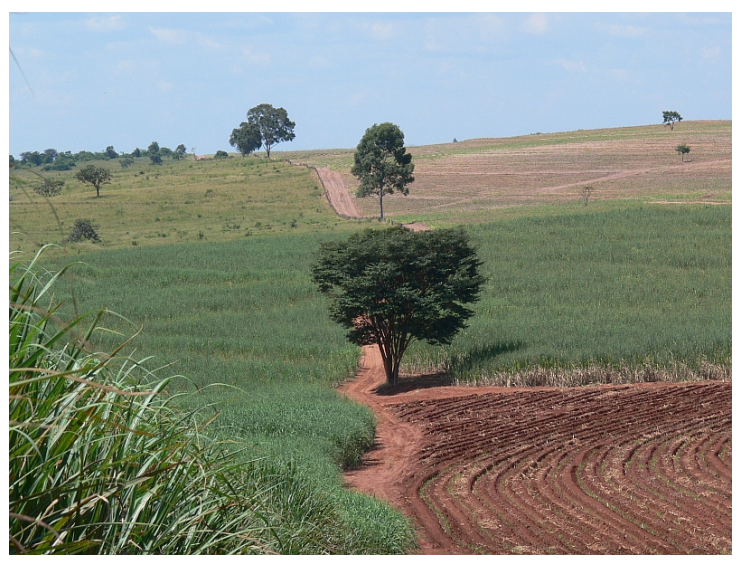

Figura 13 - Ocupação da área de estudo. Eminentemente por canaviais. 


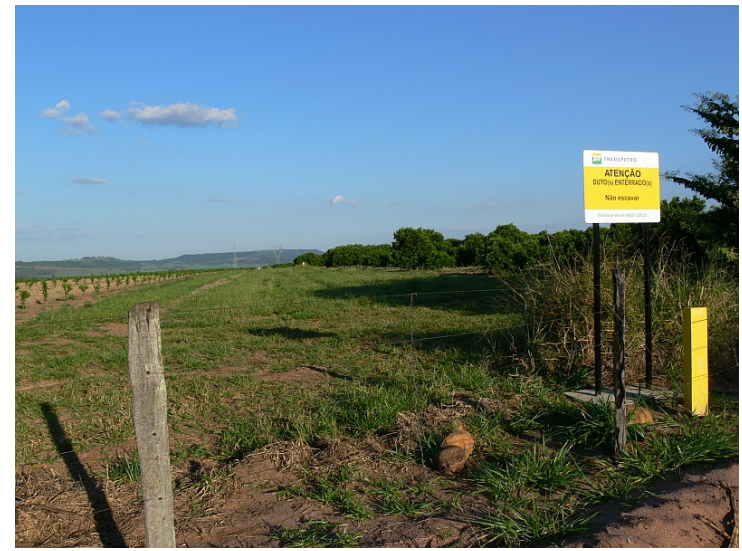

Figura 14 - Área de servidão do duto OSBRA.

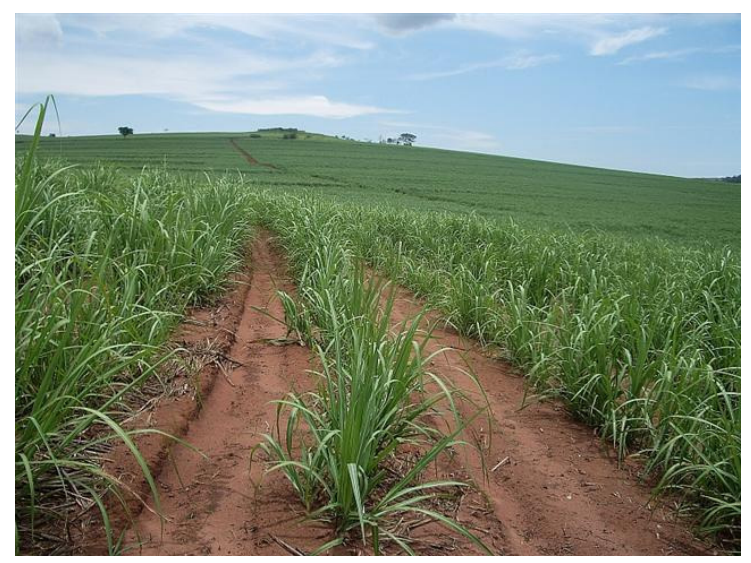

Figura 16 - Ocupação da área de estudo por canaviais

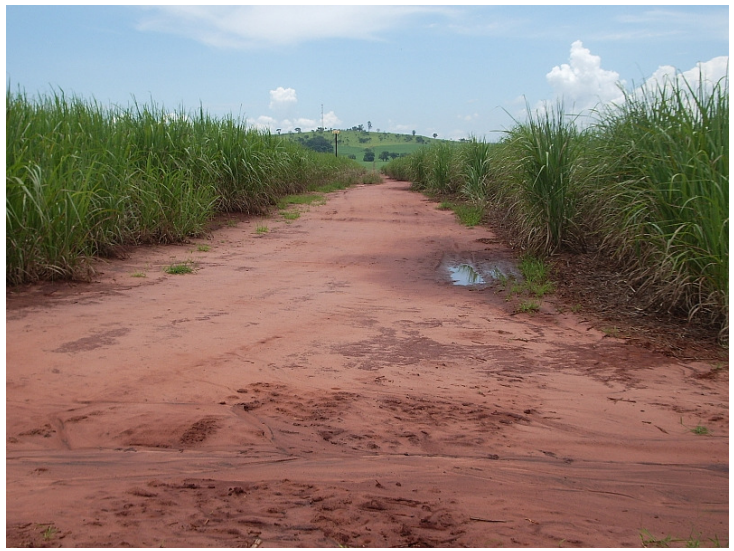

Figura 15 - llustração da área de estudo com aspectos das vias de acesso entre os canaviais.

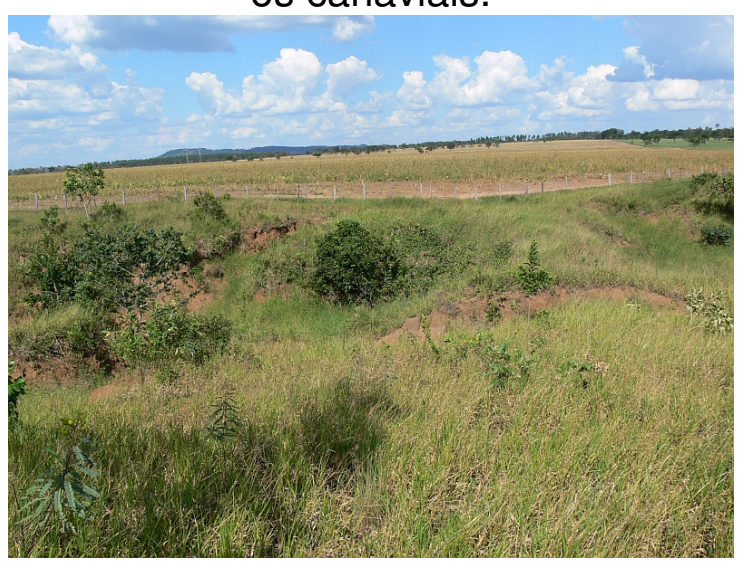

Figura 17 - Ocupação da área de estudo por pastagem.

A cultura canavieira apresenta avançado grau de degradação ambiental; observaram-se nascentes de drenagens dos tributários do Ribeirão do Tamanduá secos, assoreados e com a mata-ciliar bastante degradada e até mesmo ausente, como o córrego da Água da Cruz. 


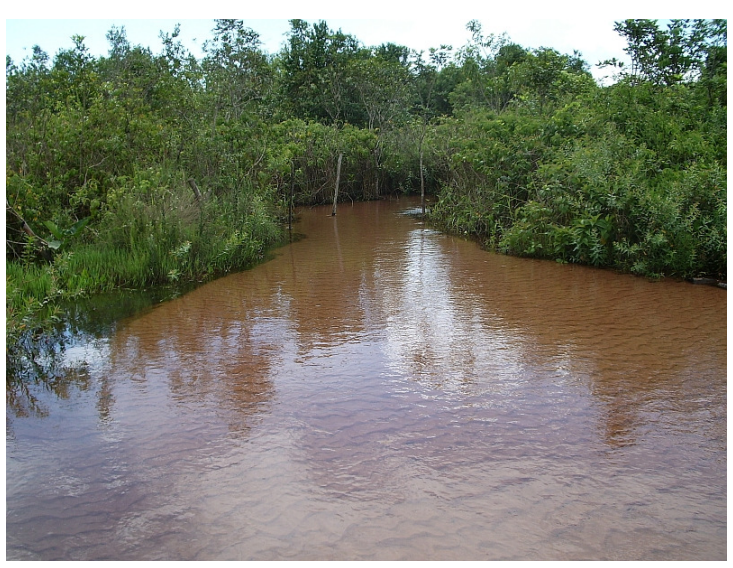

Figura 18 - Córrego Água da Cruz.

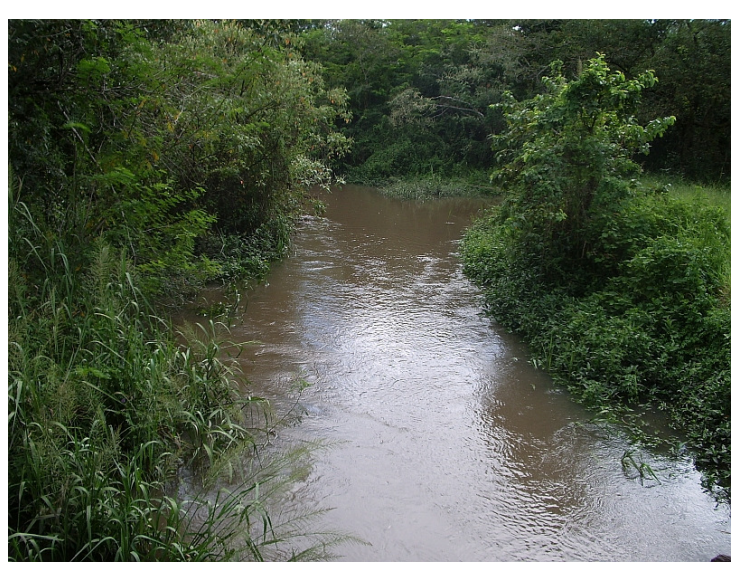

Figura 19 - Ribeirão do Tamanduá

A atividade de mineração existente é marcada pela exploração de argilas tipo ball clay, de coloração branca, denominada Argila São Simão, e de areias aluvionares, extraídos da planície de inundação do Ribeirão do Tamanduá.

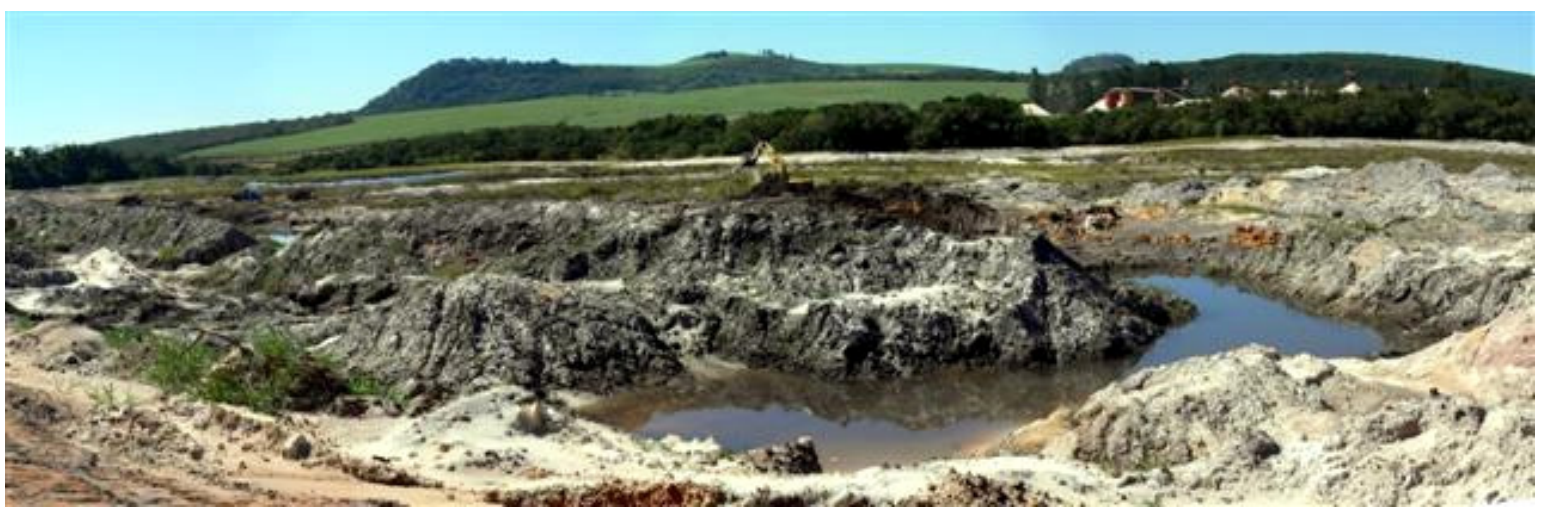

Figura 20 - Cava de mineração de argila ball clay, localizado na planície de inundação do Ribeirão do Tamanduá - Distrito de Bento Quirino - São Simão - SP 


\subsection{Geologia Regional}

A unidade estratigráfica que aflora na área de estudo é a Formação Botucatu, pertencente à Bacia do Paraná. Esta bacia sedimentar localiza-se no centro-sul da América do Sul, com $1.600 .000 \mathrm{Km}^{2}$, sendo $1.000 .000 \mathrm{Km}^{2}$ em território brasileiro, $400.000 \mathrm{Km}^{2}$ em território argentino, $100.000 \mathrm{Km} 2$ em território paraguaio e 100.000 $\mathrm{Km}^{2}$ em território uruguaio. No Brasil a bacia ocorre nos Estados de São Paulo, Paraná, Santa Catarina, Rio Grande do Sul, Minas Gerais, Mato Grosso, Mato Grosso do Sul, Goiás e se projeta pela Plataforma Continental. Tem seu nome derivado do rio Paraná, que corre paralelo ao seu eixo maior (NE-SW) e delimita as fronteiras do Paraguai e Argentina (Petri e Fúlfaro 1983).

Trata-se de uma sinéclise intracratônica da Plataforma Sul-americana, desenvolvida completamente sobre a crosta continental e preenchida por rochas sedimentares e vulcânicas que começaram a ser depositada desde o Siluriano até o Cretáceo. Apresenta um formato alongado em direção NNE-SSW e largura de 90 $\mathrm{km}$, sendo que dois terços da porção brasileira são cobertos por derrames de lava basáltica que chegam a atingir $1.700 \mathrm{~m}$ de espessura. A espessura máxima de rochas sedimentares e vulcânicas encontrada está em torno de $8.000 \mathrm{~m}$ no centro geométrico da bacia.

O conjunto de rochas que constituem a bacia do Paraná representa o empilhamento de pacotes sedimentares de, no mínimo, três diferentes ambientes tectônicos resultantes da ação de placas durante a evolução do megacontinente denominado Gondwana.

Os limites da borda da bacia variaram muito ao longo do tempo geológico, sendo que a configuração atual não retrata o que foi um grande mar conectado com - Oceano Pacífico Paleozóico e cobrindo uma extensa área do continente 
gondwânico, hoje fragmentado em pedaços que formam a América do Sul, África, Antártica, Madagascar, Austrália e Índia.

Pelo seu tamanho, pode-se considerar uma bacia pobre em recursos minerais com pequenos depósitos de carvão em depósitos deltaicos do Permiano, gemas em geodos de lavas basálticas, pequena quantidade de rochas carbonáticas. Mais relevante para o presente trabalho é a presença do maior aqüífero do planeta, o Aqüífero Guarani, em sedimentos eólicos do Jurássico. Na evolução geológica da Bacia do Paraná, o entendimento do preenchimento sedimentar é o elemento mais importante, pois deles pode-se deduzir como seria o ambiente predominante na área, como a diversidade de climas vigentes, oscilações do nível do mar, evolução tectônica que controlou as várias discordâncias e distribuiu os depocentros, áreasfonte e as fácies sedimentares.

As deformações intensas e de estilo estrutural complexo concentradas em áreas restritas, ao invés de afetarem grandes regiões da bacia, refletem uma historia deformacional típica de bacias intracratônicas, nos quais zonas de falhas e intrusões ígneas desempenham papel fundamental (Zalán et. al. 1990).

As rochas sedimentares da Bacia do Paraná foram depositadas sobre uma vasta área de escudo do recém formado Gondwana. Este supercontinente era composto por vários núcleos cratônicos (com rochas tipo granulitos e greenstone) rodeados por vários cinturões móveis e dispersamente recobertos por sedimentos molássicos, formados durante o ciclo Brasiliano (Proterozóico superior até o Ordoviciano).

A origem da bacia deve estar relacionada ao final do ciclo Brasiliano (Neordoviciano), que deixou exposto um extenso volume aquecido de crosta continental recém agrupada. Provavelmente, o subseqüente arrefecimento dos 
esforços, juntamente com o esfriamento da crosta foi suficiente para iniciar a subsidência que levou à deposição sedimentar do Siluriano. A evolução estratigráfica estrutural foi controlada por trends herdados do embasamento, que influenciaram as mudanças e distribuições de fácies sedimentares e originaram deformações localizadas (Zalán et. al. 1990).

O arcabouço estratigráfico da Bacia do Paraná consiste em cinco seqüências deposicionais de idade que vai do Ordoviciano até o Cretáceo. O preenchimento sedimentar predominantemente siliciclástico, capeado pelo mais volumoso derrame de lava basáltica ocorrido na crosta continental da Terra. A evolução estratigráfica da Bacia do Paraná se extinguiu no estagio final do rift de separação entre a África e a América do Sul, há 115 milhões de anos. Os depósitos pós-lava do Cretáceo e do Terciário indicam que a evolução estrutural ainda não foi interrompida (Zalán et. al. 1990).

\subsection{Geologia local}

A área do mapeamento geológico é compreendida pala bacia do Ribeirão do Tamanduá, tributário da margem esquerda do Rio Pardo, com direção preferencial N-S e aproximadamente $50 \mathrm{~km}$ de extensão. Pertencente a seqüência sedimentar da Bacia do Paraná, composto por seqüência Juro-cretácea de rochas vulcanosedimentares pertencentes ao Grupo São Bento, (formações Serra Geral e Botucatu) e por sedimentos neógenos.

O topo da seção é composto por basaltos da Formação Serra Geral, responsáveis pelo desenho da geomorfologia regional, sustentando os topos aplainados de morros e escarpas encontrados na região. São fontes de sedimentos 
argilosos e ferruginosos, responsáveis pela coloração vermelha impressa sobre sedimentos arenosos encontrados nas vertentes dos vales da região.

A Formação Serra Geral é composta por derrames e intrusões básicas de gabros e basaltos e associados a diques e sills intrudidos nos sedimentos da bacia, como observado em algumas soleiras da região. Estas rochas formam coberturas de alteração com grande quantidade de argila, portanto apresentam porosidade baixa, devido a as características de sua textura sedimentar. Entretanto quando pouco alteradas, apresentam-se bastante fraturadas, de origem estrutural, por alívio de pressão e resfriamento (disjunção colunar), resultando em alta permeabilidade e permitindo rápida percolação de fluídos por tais fissuras em grandes profundidades.

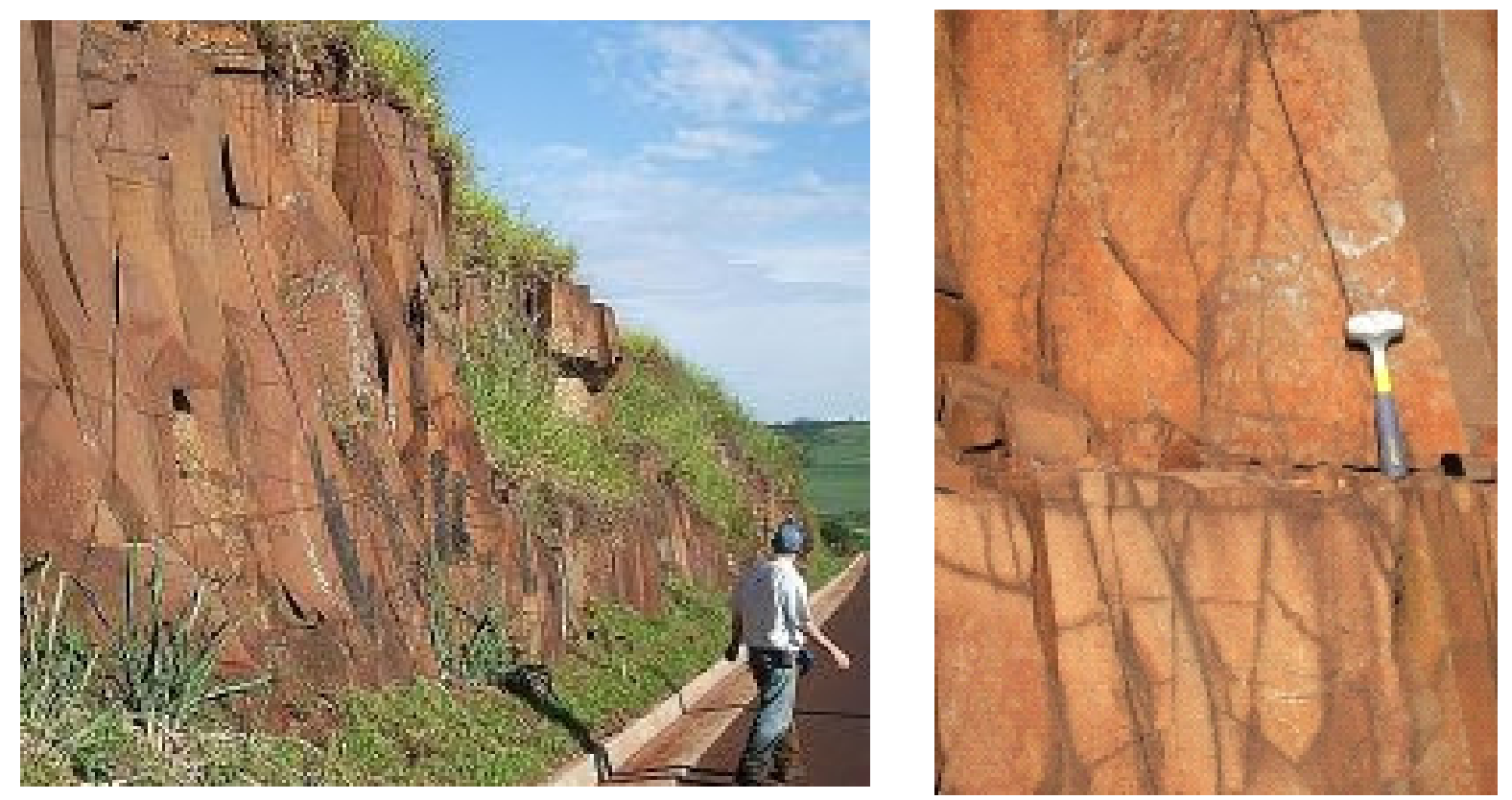

Figuras 21 e 22 - Afloramento de basalto da Formação Serra Geral existente na área de estudo.

Na Bacia do Córrego Tamanduá, as rochas do Serra Geral não apresentam grande relevância, devido à posição topográfica em que se encontram a grande maioria não se encontrando em posição de vulnerabilidade ao óleo. Mas estas rochas se fazem influenciar pelo fornecimento de material resultante de seu 
intemperismo, de granulometria fina, como a argila, e pela cimentação ferruginosa de areias. A presença deste material nas proximidades das intrusões basálticas causa diminuição de porosidade e de permeabilidade das areias.

Foram mapeadas três unidades litoestratigráficas principais, da base para o topo, onde se encontram sedimentos francamente arenosos, provenientes da decomposição de rochas da Formação Botucatu. Podem-se, ainda encontrar sedimentos litificados em locais de quebra de relevo, como na cachoeira do córrego Jaboticabal, por exemplo. A rocha intemperizada apresenta pouca a nenhuma cimentação, salvo em raros casos, onde há cimentação ferruginosa, proveniente de rochas básicas da Formação Serra Geral e grãos pouco compactados de arranjo frouxo.

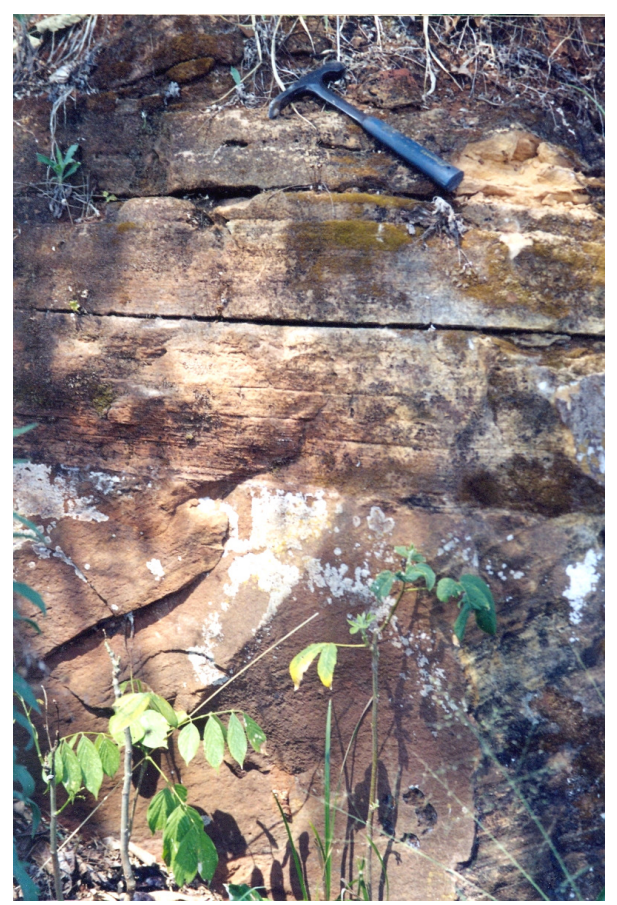

Figura 23 - Afloramento de arenito da Formação Botucatu, no Córrego Jaboticabal.

A Formação Botucatu caracteriza-se por grande homogeneidade litológica, evidenciada pela predominância de fácies de arenitos bem selecionados, com alto grau de arredondamento normalmente compondo camadas métricas a decimétricas 
lateralmente continuas. Ocorrem fácies de arenitos muito finos a finos, apresentando estratificação cruzada e acanalada de grande porte, estratificação de baixo ângulo, e localmente plano-paralelas.

Petri e Fúlfaro (1983) descrevem a Formação Botucatu como sendo constituída, predominantemente, por arenitos com seleção regular e boa, e com granulação fina e pouca matriz. Apresenta estratificações cruzadas de médio a grande porte, sendo que localmente ocorrem arenitos conglomeráticos.

Os arenitos encontrados na área de mapeamento apresentavam-se, na maioria das vezes, em avançado grau de intemperismo. Raros foram os casos de se encontrou rocha sã, apresentando-se associados a drenagens e quebras de relevos (cachoeiras). Descrições realizadas tanto em sedimentos inconsolidados como em rochas sedimentares, indicam que a composição mineralógica e seleção e tamanho de grãos se assemelhavam, apesar do estágio de alteração.

Assim, pode-se classificar o pacote sedimentar como composto por areias, em sua maioria quartzosas, bem selecionadas, granulometria predominantemente média e com porcentagem menor de grãos finos e grossos.
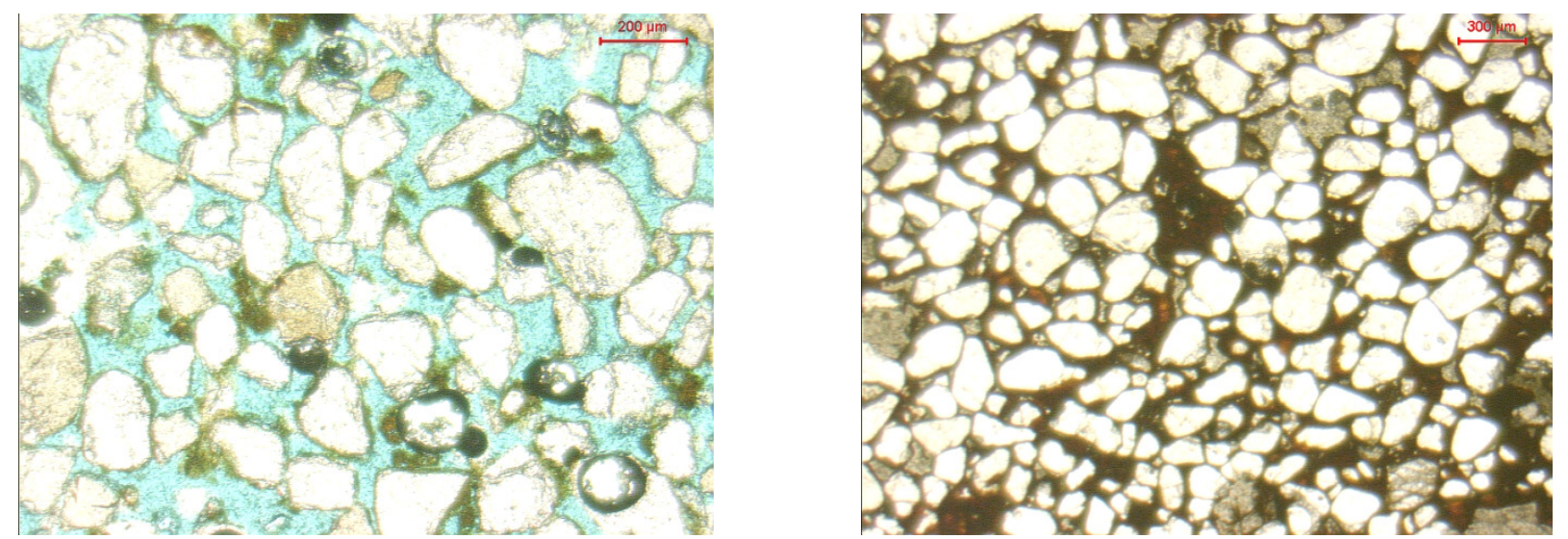

Figuras 24 e 25 - Fotomicrografias de arenitos coletado na área de estudo. A cor azul é dada pelo material de impregnação e demonstra os poros da rocha. 
Apresentam posição intermediária na topografia da área de estudo, entre as escarpas em forma de mesa de basaltos da Serra Geral e depósitos pleistocênicos da planície do Ribeirão Tamanduá. Entretanto, em geral sua ocorrência se dá como material inconsolidado ou bastante friável, sem estruturas, indicando intemperismo e erosão. É comum apresentarem coloração vermelha acentuada se estiverem próximas às escarpas de basalto.
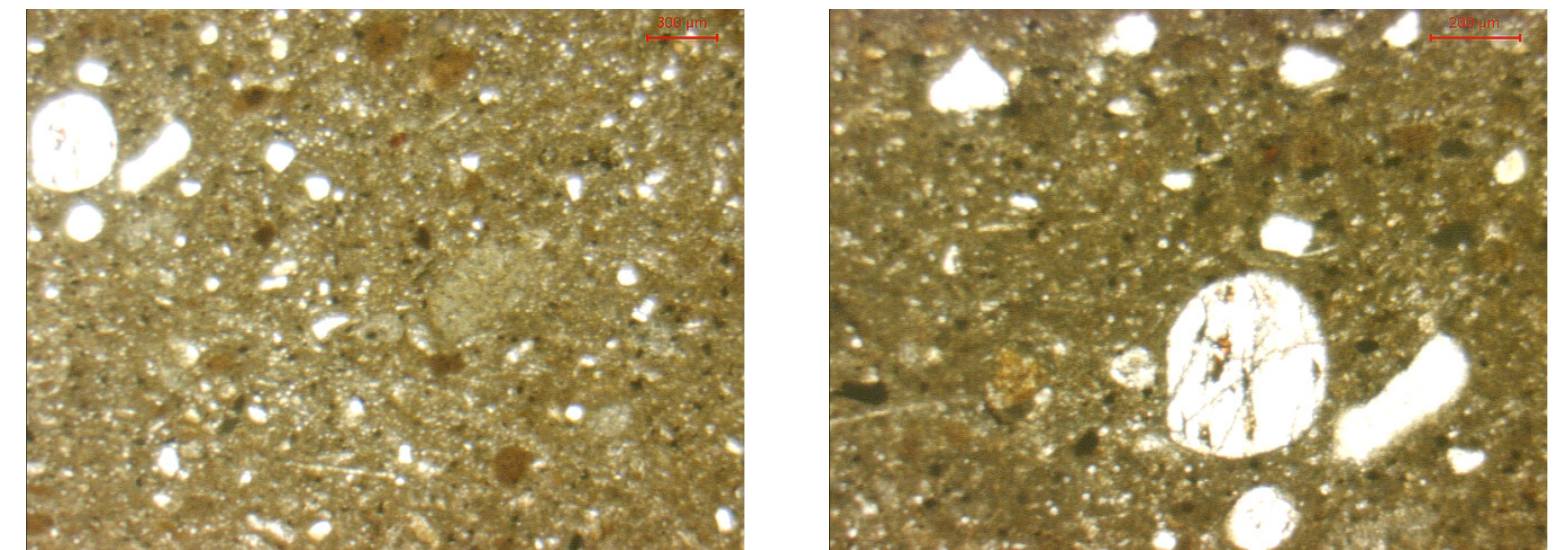

Figuras 26 e 27 - Fotomicrografias de sedimentos predominantemente argiloso com seleção muito pobre, coletados na área de estudo.

Este é o pacote sedimentar de maior importância da área de estudo, apesar de apresentar difícil identificação, por ser um sedimento com muito retrabalhamento, tanto natural como antropogênico, pois há largo histórico de cultivo e plantações de monocultura nesta área.

Foram encontrados locais onde os sedimentos apresentavam pequena influência do material proveniente da alteração do basalto, normalmente aumentando pouco o seu teor de argilas tornando a rocha avermelhada. Entretanto, há porções onde o material ferruginoso atua como cimento deste sedimento, tornando-o pouco permeável e poroso, principalmente se há proximidade com as intrusões de basalto (sills e diques). 

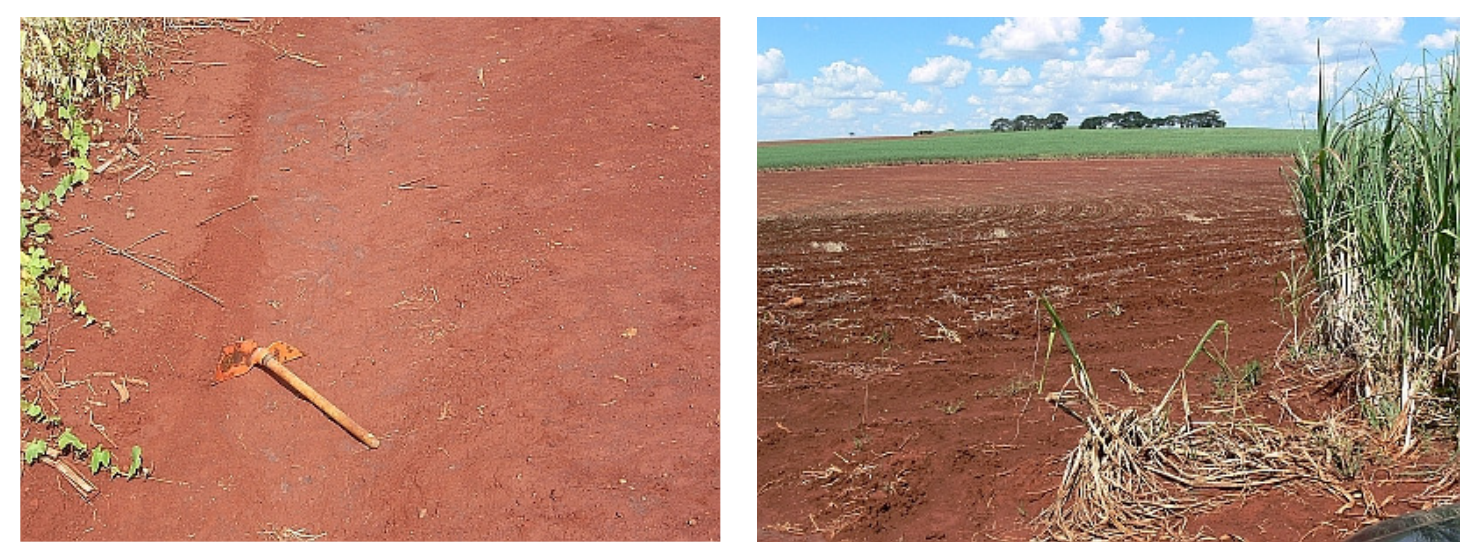

Figuras 28 e 29 - Fotos de locais de coletas de amostras da área de estudo.

Observaram-se corpos de sedimentos neógenos compostos por areias e argilas, da planície de inundação do Ribeirão do Tamanduá. Estes sedimentos podem ser divididos em três classes: corpos arenosos com granulometria fina a média, corpos argilosos, de coloração branca, caoliníticas do tipo ball clay e corpos de argilas pretas com fragmentos de material orgânico, como também observado por Pressinotti (1991). Nesta várzea é recorrente a presença de cavas e minerações que exploram estas lentes argilosas ball clay e, secundariamente, depósitos de areia.

Em posição topográfica inferior estão localizados os depósitos Pleistocênicos da bacia sedimentar do Ribeirão do Tamanduá, onde sedimentos aluvionares pleistocênicos encontram-se na forma de terraço. Podem ser divididos em duas fases de sedimentação, uma composta pelo terraço aluvionar mais jovem, onde o próprio Ribeirão está instalado, e outra situada a em nível topográfico superior. Pressinotti (1991) elaborou um mapa geológico na escala 1:25.000 para parte desta área, indicando os respectivos terraços. O mais jovem está relacionado ao nível atual do Ribeirão do Tamanduá, que recebe inundações periódicas atuais, e o terraço mais velho, que atua como limitante desta várzea.

Assim dividiu-se a bacia sedimentar em dois grupos com características distintas, de maneira, servirem aos propósitos do trabalho aqui desenvolvido. Os 
sedimentos presentes nos terraços superiores, mais velhos, apresentam influência dominante de sedimentos francamente arenosos (dados de amostras e de sondagens da Pressinotti, 1991), entretanto apresentando influência marcante do material localizado em cotas mais altas, principalmente argilas e material ferruginoso proveniente dos basaltos Serra Geral.

\subsection{Hidrogeologia}

A área de estudo está situada sobre exposições de arenitos que compõem o Aqüífero Guarani, a denominação formal dada à parte do Sistema Hidroestratigráfico Mesozóico constituído por estratos do Triássico (formações Pirambóia e Rosário do Sul no Brasil, Buena Vista no Uruguai) e do Jurássico (formações Botucatu no Brasil, Misiones no Paraguai e Tacuarembó no Uruguai e Argentina) (Araújo et al., 1995).

As características hidrogeológicas do aqüífero variam significantemente dentro desta gigantesca bacia intracratônica. Estas variações advêm da mudança do ambiente de deposição, da evolução estrutural da bacia e do tempo de residência das águas.

O aqüífero tem espessura média de 250 m e está capeado pelo pacote basáltico da Formação Serra Geral. Trata-se de um aqüífero confinado e limitado em suas margens por faixas alongadas de arenitos da Formação Botucatu, responsáveis pela sua recarga. O comportamento da água no vadoso indica que a recarga no Aqüífero Guarani é maior na época de chuva (dezembro a fevereiro), correspondendo a cerca de $90 \%$ do total infiltrado (Wendland et. al. 2004). 


\subsection{Geomorfologia}

A área de estudo localiza-se na unidade morfoescultural da Bacia Sedimentar do Paraná onde são descritos planaltos e chapadas formados por rochas básicas da Formação Serra Geral que marcam o contato com as depressões circundantes, formadas por rochas sedimentares das formações Botucatu e Pirambóia. Os contatos são marcados por escarpas identificadas como frentes de cuesta única ou desdobradas em duas ou mais frentes, sendo que no Estado de São Paulo aparecem como uma frente única (Ross e Moroz, 1997).

O relevo desta morfoescultura apresenta-se levemente ondulado com predomínio de colinas amplas e baixas com topos aplainados. Nestes planaltos identificam-se variações fisionômicas regionais que permitem delimitar unidades geomorfológicas distintas como o Planalto Centro Ocidental, Patamares Estruturais de Ribeirão Preto, Planaltos Residuais de Batatais/Franca, Planalto Residual de São Carlos, Planalto Residual de Botucatu e Planalto Residual de Marilia. A área de estudo está inserida em duas unidades morfoestruturais principais: Patamares Estruturais de Ribeirão Preto e Planaltos Residuais de Batatais/Franca.

A unidade morfoescultural denominada Patamares Estruturais de Ribeirão Preto apresenta formas de relevo denudacionais, cujo modelado constitui-se por colinas amplas e baixas com corpos tabulares, vales de entalhamento médio com menos de $20 \mathrm{~m}$ e a dimensão interfluvial variando de 750 a até mais de $3.750 \mathrm{~m}$. A altimetria varia entre 500 e $700 \mathrm{~m}$ e as declividades médias estão entre 2 e 10\%. Os principais rios que drenam esta unidade são Mogi - Guaçu, Pardo e Ribeirão Preto.

A unidade morfoescultural denominada Planaltos Residuais de Batatais/Franca corresponde ao reverso da cuesta no interflúvio Mogi - Guaçu - Grande, onde predominam formas de relevo denudacionais, cujo modelado constitui-se 
basicamente por colinas de topos aplainados ou tabulares, com vales entalhados de 20 a 40 m e dimensão interfluvial média de 750 a 3.750 m. As altimetrias variam entre 800 a $1.100 \mathrm{~m}$ e as vertentes apresentam declividades que variam entre 2 e $10 \%$. Por se tratar de áreas altas e circundadas por terras baixas é um centro dispersor de drenagem (Ross e Moroz, 1997).

\subsection{Duto OSBRA}

Transporte de fluidos por dutos não é uma novidade na história da humanidade, havendo registros de civilizações antigas, gregas e romanas, por exemplo, que utilizavam dutos para o transporte de água.

Em 1863 foi construído nos EUA o primeiro oleoduto, após a perfuração do poço Drake resultando no aumento da produção de petróleo. Até então, o transporte era feito por carroças, com o produto armazenado em barris, desde o campo de produção até a refinaria ou local de armazenamento (Neiva, 1993).

O oleoduto é um eficiente meio de transporte, pois possibilita maior economia, rapidez e segurança no deslocamento de grandes quantidades de hidrocarbonetos. A sua construção requer altos investimentos, exigindo acurados estudos que justifiquem o resultado vantajoso em relação a alternativas de transporte.

A utilização de dutos visa o transporte de hidrocarbonetos entre campos de produção, terminais, bases de abastecimento e refinarias assumindo importante papel na comunicação entres estes, considerando as grandes distâncias a serem percorridas, e as dimensões do território brasileiro. O uso de transporte rodoviário ou ferroviário pode se apresentar menos eficiente e econômico, além de aumentar a possibilidade de acidentes e derrames. 
Em terra, a escolha do traçado é seguida pelo levantamento topográfico e preparação dos terrenos por onde passará a instalação. Para que o óleo transportado pelo duto transponha elevações, colinas, morros e vales são utilizados estações de recalque, localizadas em determinados pontos ao longo da linha.

Nessas estações o percurso do liquido é permanentemente controlado medindo-se a temperatura, pressão de sucção e recalque, densidade e vazão. Todo o percurso é monitorado, possibilitando a localização exata de cada lote.

O calibre do duto varia de acordo com a sua utilização; o oleoduto OSBRA apresenta um conjunto de duas tubulações com diâmetros de 50,8cm (20 polegadas) e de $30,48 \mathrm{~cm}$ (12 polegadas), com um comprimento de $964 \mathrm{~km}$, ligando a Refinaria de Paulínia (REPLAN), localizado no próprio Município de Paulínia, Estado de São Paulo até o Terminal de Brasília, localizado em Brasília, Distrito Federal.

Na figura 30 é apresentado o traçado do oleoduto OSBRA, desde a Refinaria REPLAN até o Terminal de Brasília. 


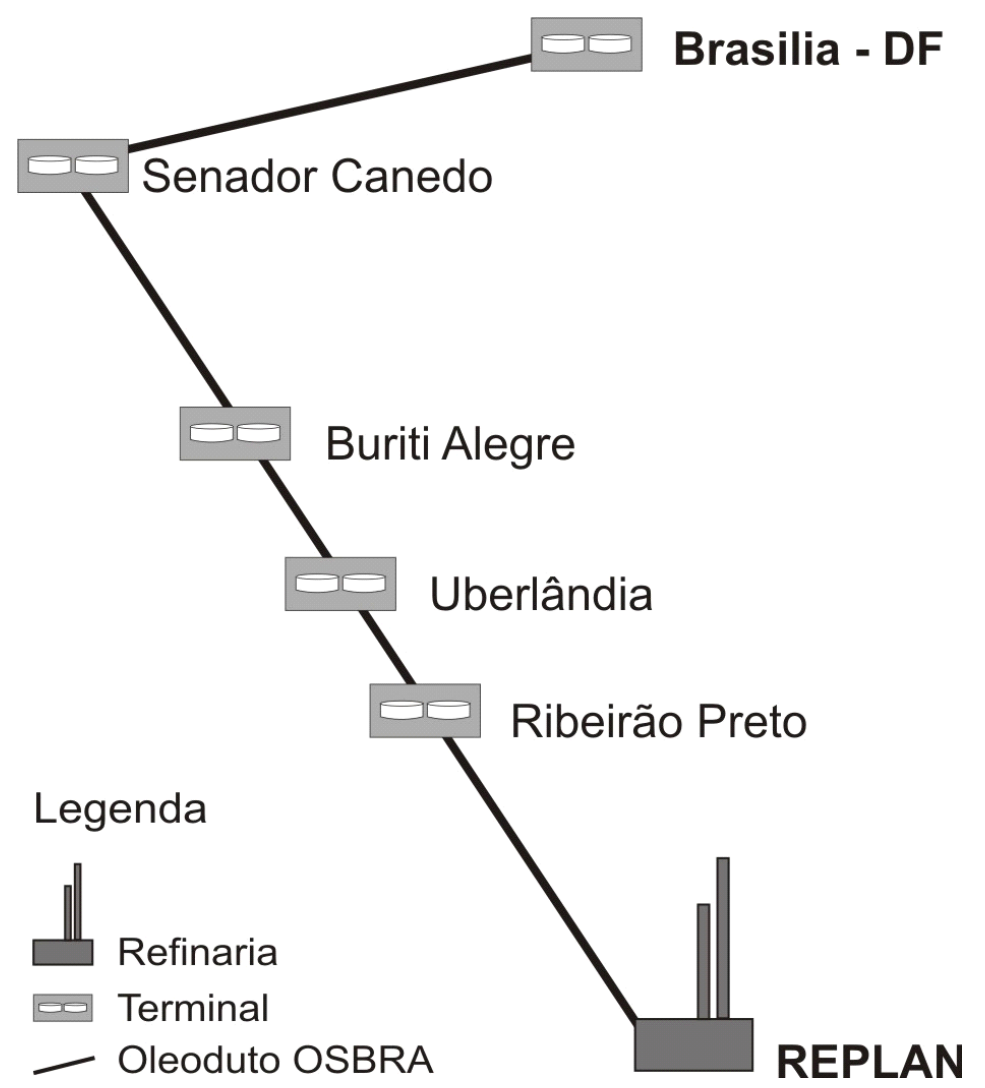

Figura 30 - Traçado esquemático do oleoduto OSBRA. Modificado de Transpetro, 2007.

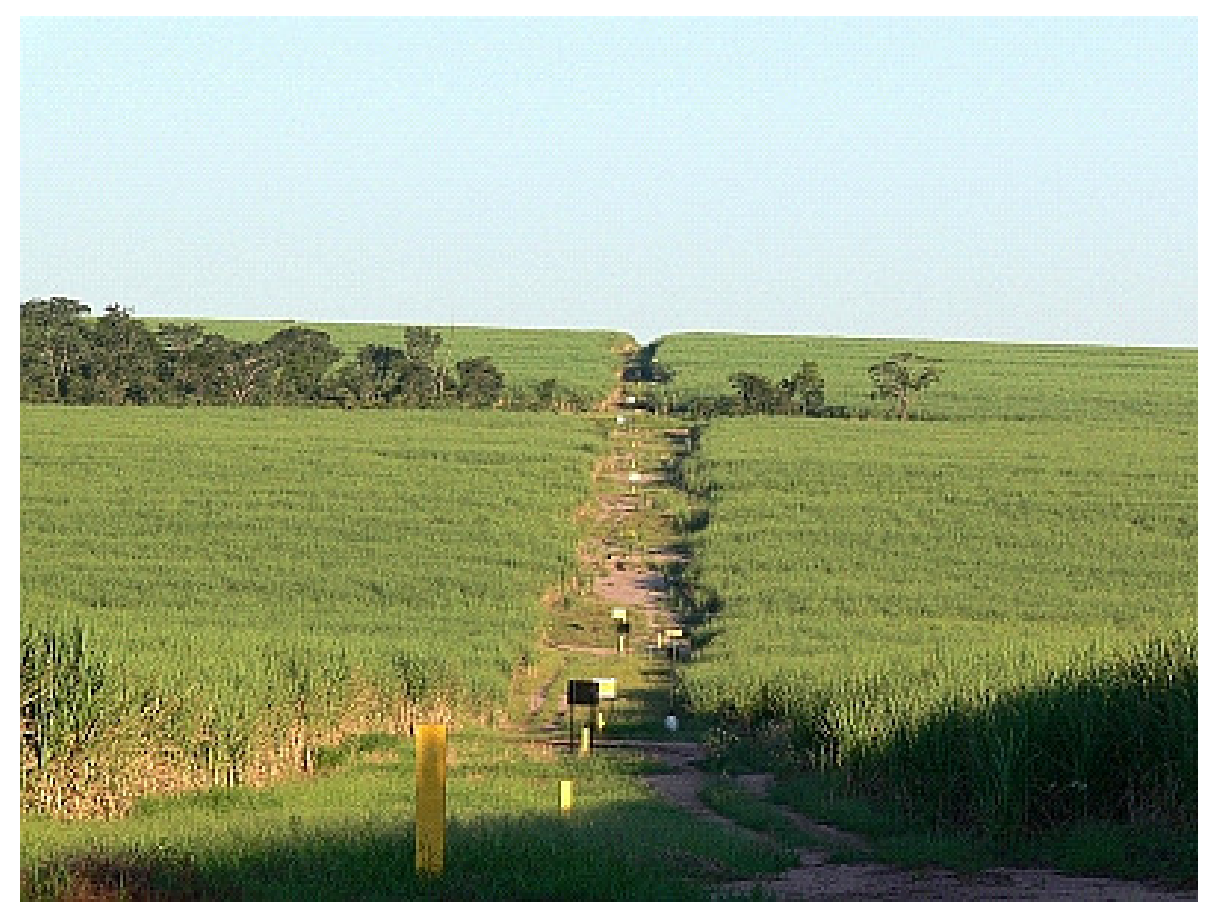

Figura 31 - Faixa de servidão do duto OSBRA, na área de estudo. 


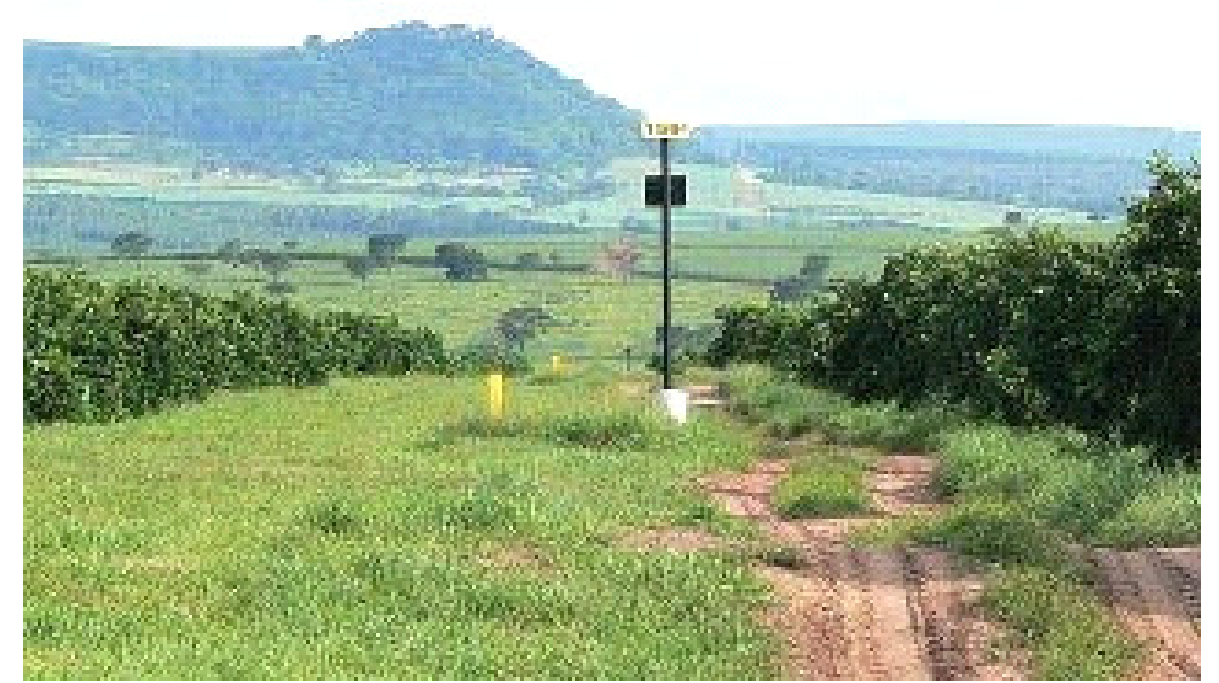

Figura 32 - Faixa de servidão do duto OSBRA, na área de estudo.

As fotos acima, ilustram a faixa do duto OSBRA, em meio as diferentes paisagens encontradas na Bacia do Ribeirão do Tamanduá, municípios de Cravinhos e São Simão, SP.

\subsection{Utilização de parâmetros texturais na elaboração da Carta SAO da Bacia do Ribeirão do Tamanduá}

O estudo da aplicação de parâmetros texturais na elaboração da Carta SAO da Bacia do Ribeirão Tamanduá, foi realizado em três etapas, conforme esquema apresentado na Figura 33. 


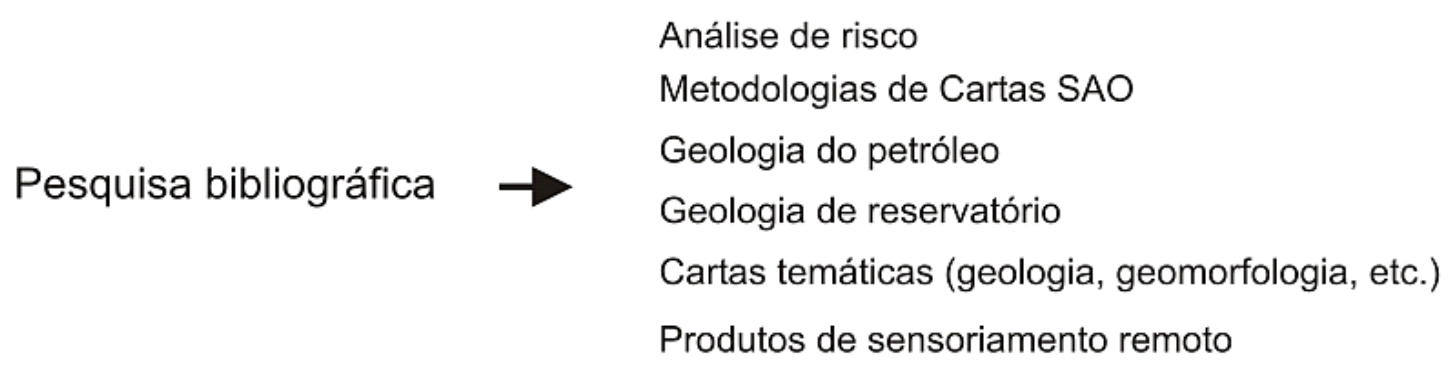

Figura 33 Primeira etapa: levantamento bibliográfico.

$\mathrm{Na}$ análise bibliográfica, foram investigados os acidentes ocorridos não apenas com hidrocarbonetos, mas também com outros líquidos poluentes, como rejeitos de beneficiamento de minérios, efluentes domésticos e demais produtos químicos, assim como foram analisados os métodos propostos para elaboração de Cartas de Sensibilidade ao Derramamento de Óleo - Cartas SAO.

No estudo das propostas metodológicas de elaboração de Carta SAO, como os de Oliveira et al. (2003), Davis e Wireman (2002), MMA (2001), NOAA (1997), IPIECA e IMO (1996), Hayes et al., (1994) API e NOAA (1994) e Gundlach e Hayes (1978), especial atenção foi dada na análise dos parâmetros geológicos utilizados.

Um dos principais problemas relativos ao meio físico, associado a um acidente de derramamento de óleo em área continental, é a contaminação da água subterrânea. Por esse motivo, foram também investigados os trabalhos relacionados à geologia de reservatório. Estes estudos mostraram-se importante fonte de insumos para o entendimento da relação entre a textura sedimentar, porosidade e a permeabilidade do substrato o que, por sua vez, encontra-se relacionado à sensibilidade ambiental. Os principais parâmetros de textura sedimentar, relacionados à porosidade e permeabilidade, são granulometria, seleção, arredondamento e esfericidade dos grãos e presença ou não de cimento. 
A partir do sensoriamento remoto foram realizadas interpretações sobre as características geomorfológicas e das bacias hidrográficas vulneráveis ou não ao óleo, como proposto por Hayes et. al. (1994), supondo ruptura acidental ocorrida no duto OSBRA. Da geologia sedimentar foram selecionados os parâmetros determinantes à porosidade e permeabilidade do sedimento, e da conseqüente percolação do contaminante para o aqüífero. Da geoestatística foram obtidas técnicas de amostragem e de interpolação e extrapolação dos dados coletados, para a realização da krigagem ordinária da textura sedimentar da área experimental.

A partir de cartas temáticas como o Mapa Geológico do Estado de São Paulo, na escala 1:500.000 (IPT 1982), e mapeamentos realizados por Pressinotti (1991), nas escalas 1:50.000 e 1:25.000, da Bacia do Ribeirão do Tamanduá (figura 34 A), foi obtido o conhecimento regional da área experimental utilizada para a aplicação dos métodos e parâmetros aqui propostos.

Selecionada a área onde o duto OSBRA corta os mencionados arenitos, foram realizados estudo das drenagens, através de mapas topográficos, fotografias aéreas e imagens de satélite, para distinção das áreas que podem ser atingidas pelo óleo (vulneráveis), no caso de acidente com o duto, das áreas que não seriam atingidas (não vulneráveis), segundo recomendação de Hayes et al. (1994) - figura 34 B (Anexo A).

A partir do mapa da figura $34 \mathrm{~B}$, foram excluídas as áreas que se situam em cotas altimétricas superiores ao do duto, ou seja, áreas impossíveis de serem atingidas pelo óleo (figura $34 \mathrm{C}$ ), sendo essa área menor a que exige o detalhamento necessário. Através desse procedimento, ocorre uma otimização dos esforços e recursos e maior foco nas ações de resposta aos acidentes. 
Delimitada a área efetiva de ser atingida num eventual acidente, essa passa a ser a área que requer a elaboração da Carta SAO, sendo essa a investigada com mais detalhe, com coletada de amostras para determinação da granulometria, por peneiramento e pipetagem, e caracterização petrográfica, segundo mapa de pontos no Anexo B.

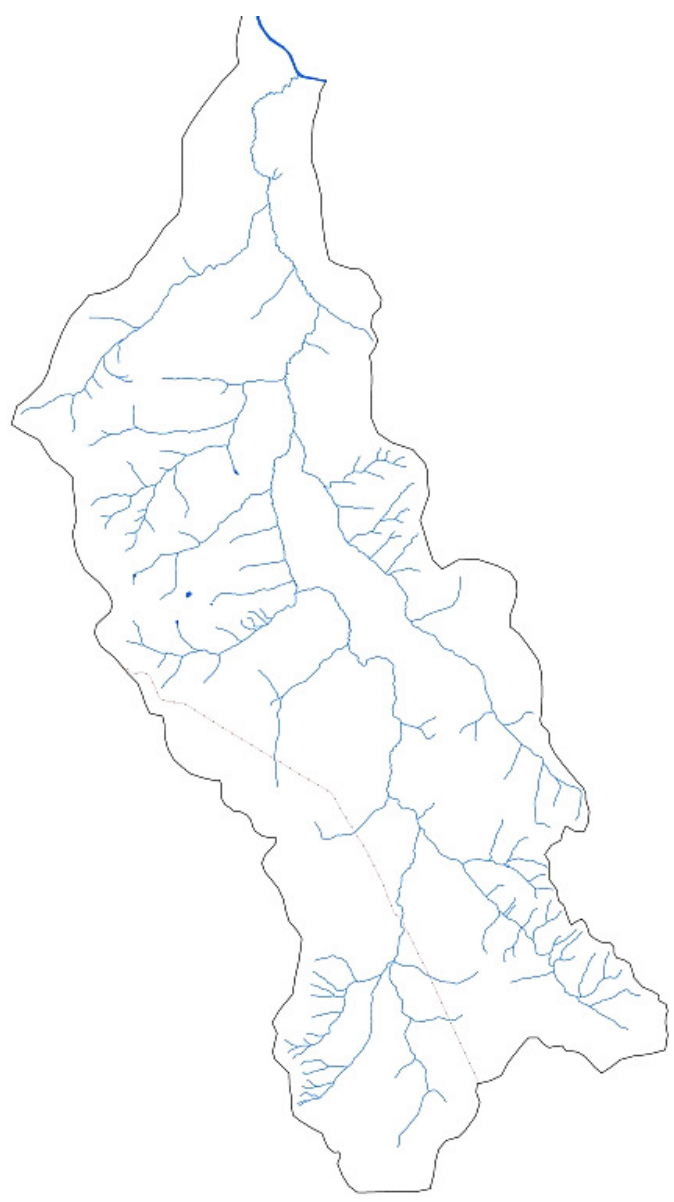

Figura $34 \mathrm{~A}$ - A figura acima ilustra a bacia geral da área afetada, com todas as subbacias. Bacia do Ribeirão do Tamanduá, Cravinhos - SP.

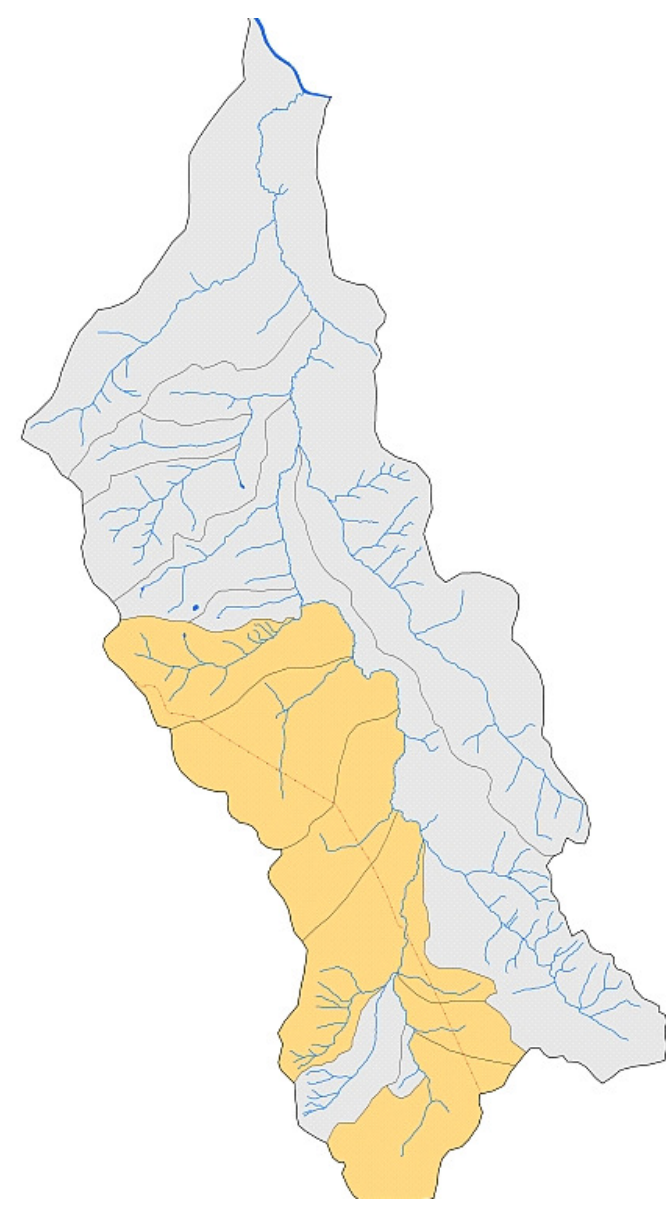

Figura $34 \mathrm{~B}$ - A figura ilustra a determinação das bacias vulneráveis, ou seja, aquelas que podem receber qualquer quantidade de material derramado e as não vulneráveis, ou seja, aquelas que nada sofrerão. Bacia do Ribeirão do Tamanduá, Cravinhos - SP. (Mapa em maior escala no Anexo A)

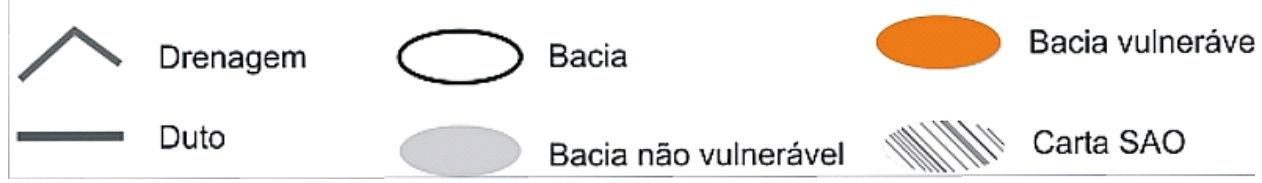




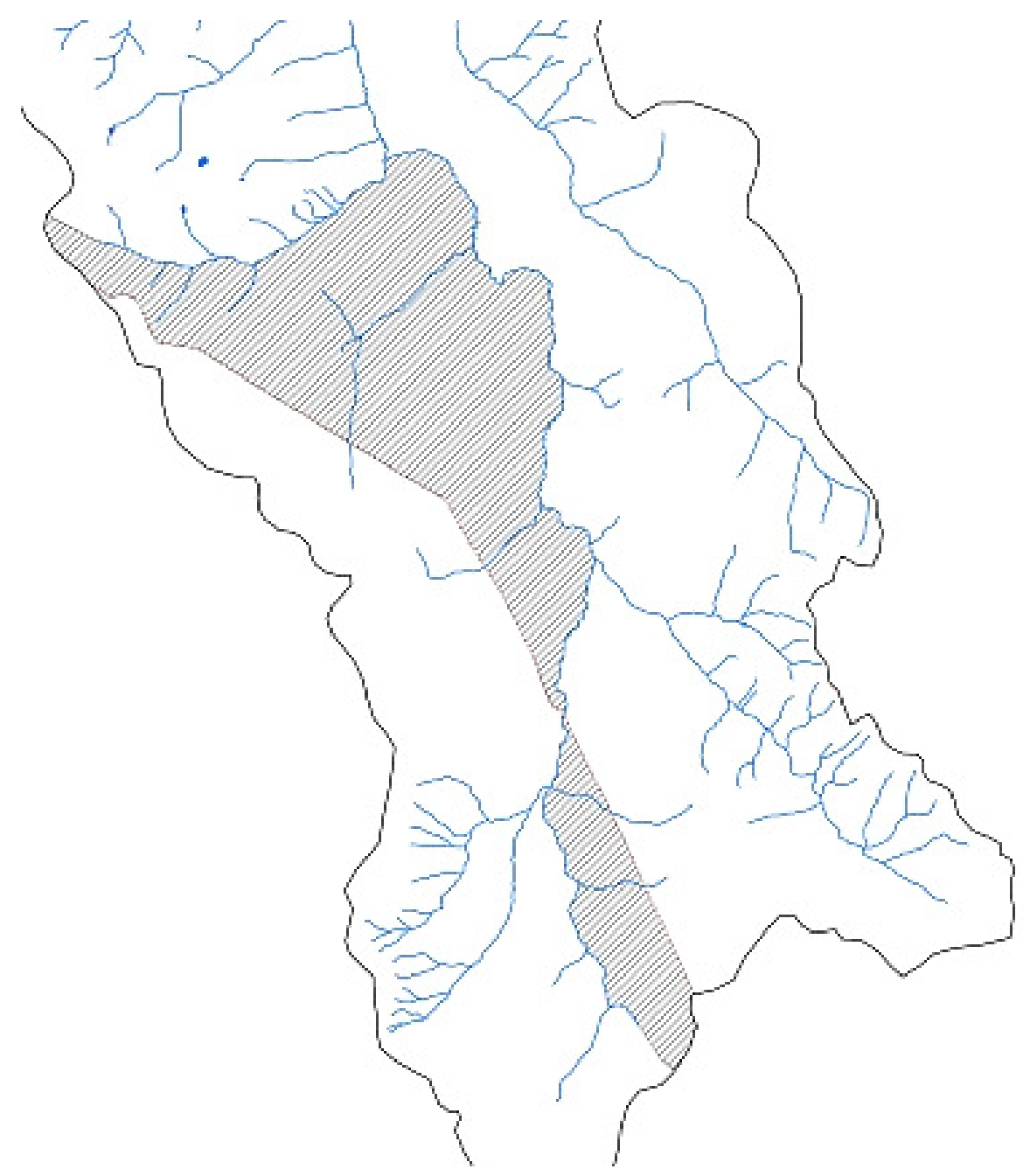

Figura 34 C- A figura acima ilustra a delimitação final da área de estudo e de elaboração da Carta SAO. Nota-se redução da área inicial para a final. Bacia do ribeirão do Tamanduá, Cravinhos - SP. (Detalhes no Anexo B)

Os dados de campo foram tratados por analise geoestatística, buscando o modelo de variabilidade e correlação espacial, utilizando-se de análises de variograma com variáveis regionalizadas, a fim de estabelecer uma estimativa precisa da variação dos valores obtidos no terreno, segundo método apresentado por Yamamoto (2001). Neste caso, busca-se determinar um mapa de isovalores pela união de valores semelhantes seleção e tamanho de grãos. Estes valores foram 
integrados e tratados em ambiente SIG para a obtenção da sensibilidade do terreno ao derramamento de óleo.

Em estudos realizados por Benito et al. (2001), a partir do derramamento de água ácida resultante de lavra e beneficiamento de pirita na Espanha, a geomorfologia foi considerada o parâmetro fundamental para a previsão do comportamento do fluxo de um possível derramamento de líquido poluente em áreas continentais, já que o padrão de drenagem e seu comportamento, como regime de inundação, são os principais fatores a serem considerados.

A partir da definição das áreas vulneráveis, o método consiste na determinação da sensibilidade destas áreas. A definição dos parâmetros estudados para a delimitação da sensibilidade da bacia baseia-se a partir de métodos proposto por Foster e Hirata (1991), Davis e Wireman (2002) e Oliveira et al. (2003). O trabalho de Foster e Hirata (1991) é voltado para contaminação de aqüíferos, o de Davis e Wireman (2002) para áreas cársticas e o de Oliveira et al. (2003) voltado para mapas de sensibilidade ambiental para faixas de dutos terrestres. Os três trabalhos consideram como parâmetros as características físicas do ambiente vadoso, como a litologia, porosidade e permeabilidade. As figuras a seguir ilustram a evolução do processo de seleção da área de estudo, ou seja, a diminuição do local onde foram realizadas as coletas de amostra para análise da textura dos sedimentos.

No presente estudo, a sensibilidade ambiental foi definida numa escala dividida em cinco níveis como proposto por Oliveira et al. (2003) e Davis e Wireman (2002), determinando pesos a cada parâmetro a ser analisado. Cada parâmetro terá um valor numérico próprio, ou índice de sua sensibilidade, dividido em cinco níveis balizados pelos valores mínimos e máximos encontrado em fontes bibliográficas. 
Os trabalhos de mapeamento geológico das áreas vulneráveis serviram não somente para a elaboração de um mapa geológico na escala 1: 130.000 (Anexo C), mas também para a determinação de áreas com distintas sensibilidades ambientais ao derramamento de óleo permitindo sua classificação e indexação.

O Ribeirão do Tamanduá é uma drenagem de terceira ordem, afluente da margem esquerda do Rio Pardo formado por mais de 17 sub-bacias, das quais sete localizados a margem esquerda foram identificadas como sendo vulneráveis a qualquer grandeza de derramamento de óleo proveniente do duto. Determinaram-se sete sub-bacias vulneráveis, as dos córregos Santa Maria, Água da Cruz, drenagens C, E, F e do próprio talvegue do Ribeirão do Tamanduá.

$\mathrm{Na}$ segunda etapa, foram escolhidos os parâmetros geológicos (textura sedimentar e litologia), geomorfológicos (bacia hidrográfica e declividade) e desenvolvida a classificação e quantificação destas variáveis para indexação e determinação das classes de sensibilidade ambiental. Buscou-se utilizar um número limitado de parâmetros para análises quantitativas e qualitativas, objetivando o número baixo de dados a serem considerados, visando à diminuição de custos de campo, análises laboratoriais, profissionais envolvidos e, principalmente, pela dificuldade de obtenção de dados primários sobre o meio ambiente. 


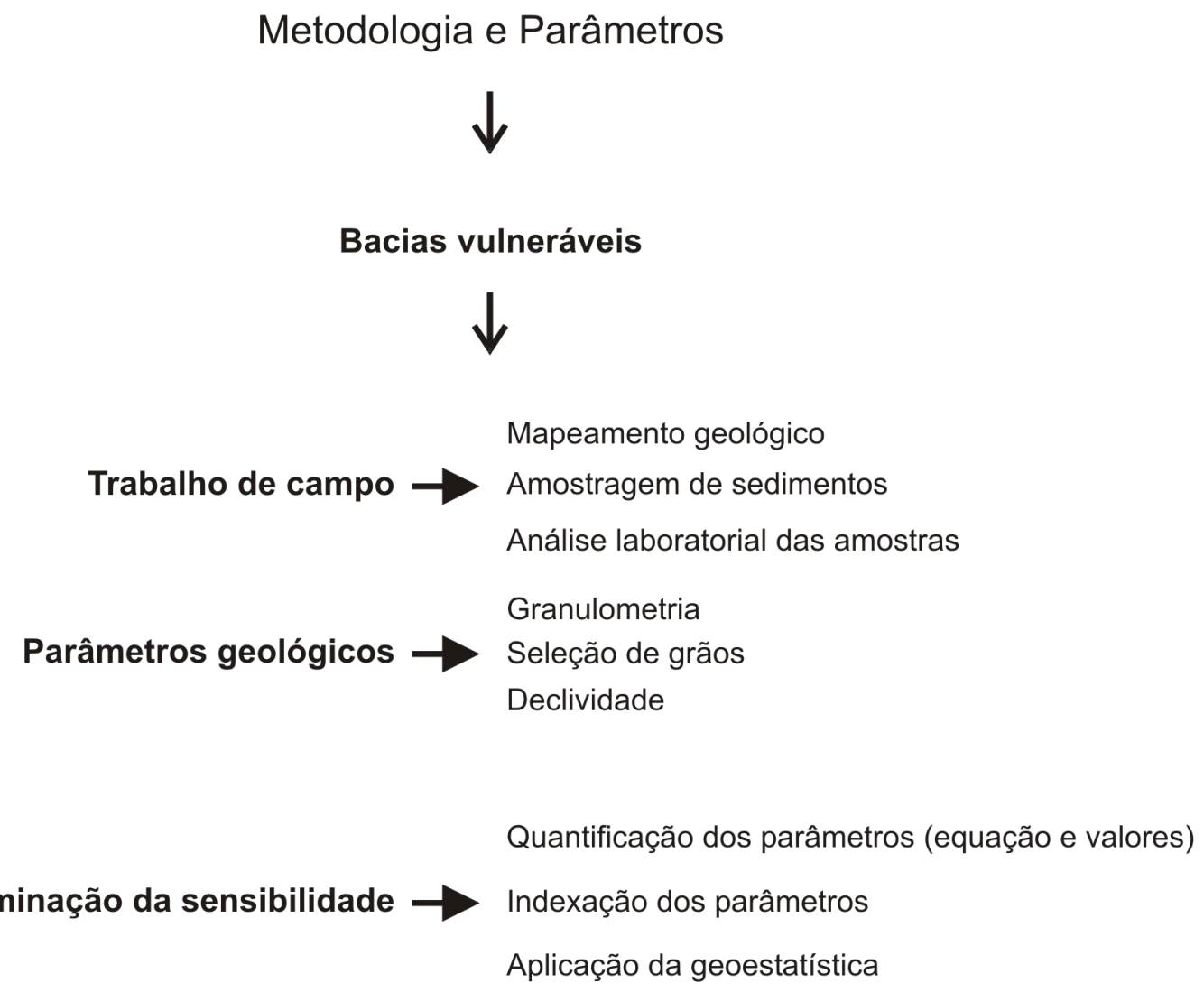

Figura 35 - segunda etapa da dissertação, marcado pela determinação de metodologia a parâmetros.

Forster e Hirata (1991) concluem pela diminuição e simplificação da lista de parâmetros a serem utilizados na identificação de vulnerabilidade de aqüíferos, para que o trabalho se torne prático e viável e, desta forma, exeqüível. A dificuldade de obtenção de dados elaborados e complexos para este tipo de avaliação se confronta entre a necessidade de dados detalhados frente a total ou parcial ausência de dados disponível.

Os parâmetros geomorfológicos foram obtidos pela interpretação de produtos variados de sensoriamento remoto como fotografias aéreas, na escala de 1:35.000, Imagem Cibers, Cartas Geomorfológica do Estado de São Paulo, na escala 1:500.000, Ross e Moroz (1997), Cartas Topográficas (folhas Cravinhos, Serrana e Luis Antônio, na escala 1:50.000 do IBGE, 1982) e levantamento em campo, o que 
permitiu a determinação dos parâmetros que influenciam o comportamento do óleo frente ao relevo, como a rede de drenagens e declividade do terreno, como apresentado por Oliveira et. al. (2003), Davis e Wireman (2002), Benito et. al. (2001), Leal (1995), Hayes et. al. (1994) e Forster e Hirata (1991)

Para a obtenção dos parâmetros geológicos foram realizados mapeamentos geológicos e coletas de amostras apenas na área considerada vulnerável, ou seja, sujeita a ser atingida. Estes processos permitiram a elaboração de um mapa geológico da Bacia do Ribeirão do Tamanduá, na escala de 1:50.000, e da análise laboratorial dos sedimentos amostrados, obtendo informações sobre suas características texturais sedimentares, como o tamanho e seleção dos grãos.

Segundo estudos realizados por Florez e Mavko, 2003, Oliveira et. al. (2003), Davis e Wireman (2002), Forster e Hirata (1991), Selley (1998), Pettijohn, et. al. (1987), Nagtegaal (1978) e Beard e Weyl (1973), as características da textura sedimentar, como o tamanho, seleção, empacotamento, arredondamento e mineralogia atuam como determinantes da porosidade e permeabilidade dos sedimentos, permitindo a interpretação do potencial de contaminação dos sistemas vadoso e freático, influenciando diretamente na sua sensibilidade ambiental.

Por fim, os dados foram agrupados em três classes de qualificação dos parâmetros: a granulometria, a seleção dos grãos e a declividade das bacias vulneráveis ao óleo. Estas classes foram quantificadas em cinco níveis de distintos valores de sensibilidade (muito baixo, baixo, médio, alto e muito alto), que interpolados resultarão em valores correspondentes aos do índice de sensibilidade ambiental, ou seja, a sensibilidade do terreno ao derramamento de óleo. 
Aplicação do método e dos parâmetros em área experimental

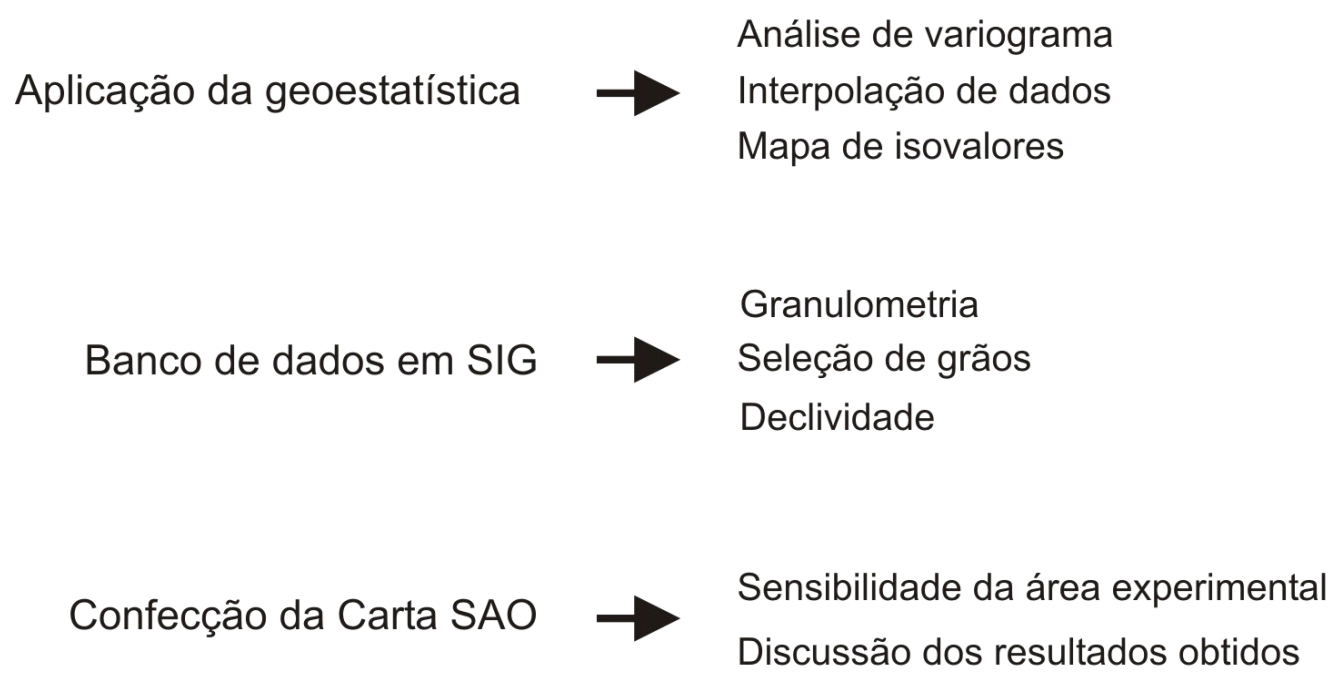

Figura 36 - terceira etapa da dissertação, marcado pela aplicação do método e parâmetros em área experimental.

Nas tabelas 7A e 7B são apresentadas as classes e valores dos parâmetros geológicos e sua indexação utilizados no cálculo da sensibilidade de ambientes continentais, propostos nesse trabalho.

Tabela 7A - Indexação dos valores estipulados aos parâmetros geológicos.

\begin{tabular}{|c|c|c|c|c|c|}
\hline Classe & $\begin{array}{c}\text { Declividade } \\
(\%)\end{array}$ & $\begin{array}{c}\text { Granulometria } \\
(\boldsymbol{\Phi})\end{array}$ & Granulometria & $\begin{array}{c}\text { Seleção } \\
\mathbf{d e} \\
\text { grãos (o } \\
\mathbf{d e} \boldsymbol{\Phi})\end{array}$ & $\begin{array}{c}\text { Seleção de } \\
\text { grãos }\end{array}$ \\
\hline 1 & $>21$ & $14-8$ & Argila & $>4$ & $\begin{array}{c}\text { Extremamente } \\
\text { pobre }\end{array}$ \\
\hline 2 & $15-20$ & $8-5$ & $\begin{array}{c}\text { Silte fino a } \\
\text { médio }\end{array}$ & $<2-4$ & Muito pobre \\
\hline 3 & $10-15$ & $5-3$ & $\begin{array}{c}\text { Silte grosso a } \\
\text { areia m.fina }\end{array}$ & $>1-2$ & Pobre \\
\hline 4 & $5-10$ & $3-1$ & $\begin{array}{c}\text { Areia fina a } \\
\text { média }\end{array}$ & $>0,5-1$ & Moderada boa \\
\hline 5 & $<5$ & $<1$ & $\begin{array}{c}\text { Areia grossa a } \\
\text { grânulo }\end{array}$ & $<0,5$ & Boa \\
\hline
\end{tabular}


Tabela 7B - Intervalos da nota e determinação de sensibilidade ambiental.

\begin{tabular}{|c|c|}
\hline Intervalo da nota & Sensibilidade \\
\hline $0-1$ & Muito baixa \\
\hline$>1-2$ & Baixa \\
\hline$>2-3$ & Média \\
\hline$>3-4$ & Alta \\
\hline$>4-5$ & Muito Alta \\
\hline
\end{tabular}

Os valores obtidos para a determinação da sensibilidade ambiental foram contabilizados de acordo com a equação 1 , a qual é uma equação de média ponderada dos valores estabelecidos pela tabela 7A. Assim, cada parâmetro classificado, será enquadrado dentro do intervalo de classe determinado, assumindo um valor definido (de um a cinco). Estes valores são aplicados à equação, e os intervalos de nota fornecem o valor final de sensibilidade ambiental, que representará a interpolação dos valores da declividade, seleção e tamanho dos grãos de sedimentos coletados na área.

O intervalo de nota representa o alcance de cada classe de sensibilidade, cuja função é orientar e padronizar o arredondamento dos valores numéricos obtidos pela aplicação dos parâmetros obtidos, ou seja, é o resultado da intersecção dos valores do terreno. A escala de granulometria e a seleção de grãos foram utilizadas na escala phi $(\Phi)$ por serem valores inteiros, tornando mais fácil a utilização e visualização dos dados.

Na equação 1 , onde: $D$ - valor da declividade; $P_{o}$ - valor da porosidade; $P_{e}-$ valor da permeabilidade; $p$ - valor dos pesos (igual a 1 ), $\Sigma_{p}$ - intervalo da nota e $X_{s}-$ valor final da sensibilidade para ambiente continental, o peso dado a cada classe foi estabelecido em um, devido a complexidade de estabelecer qual parâmetro apresenta a maior influência na sensibilidade. 


$$
(D \times p)+\left(P_{o} \times p\right)+\left(P_{e} \times p\right)=\Sigma_{p}=X_{s}
$$

3

Equação de sensibilidade de ambientes continentais

Oliveira et. al. (2003) estabelece pesos no cálculo da vulnerabilidade, estabelecendo pesos de $10 \%$ para a geologia, 15\% para a pedologia e $15 \%$ para a declividade (geomorfologia), procedimento esse não adotado no presente trabalho.

A terceira e última etapa do método empregado no desenvolvimento deste trabalho foi a aplicação dos métodos e parâmetros propostos em área experimental, buscando o testar e discutir os resultados obtidos.

Para o desenvolvimento desta etapa, criou-se um banco de dados em ambiente SIG (Sistema de Informações Geográficas) para obtenção de resultados precisos e georreferenciados da Carta SAO do Ribeirão do Tamanduá. Entretanto antes que os valores pontuais de granulometria e seleção pudessem ser inseridos no banco, foram tratados por análise geoestatística, buscando o modelo de variabilidade e correlação espacial, utilizando-se de análises de variograma com variáveis regionalizadas, a fim de se realizar krigagem ordinária a fim de estabelecer a estimativa precisa da variação dos valores no terreno (Anexos $D$ e E).

A declividade foi extraída a partir de um modelo digital de terreno, divido nos cinco níveis e com seus valores convertidos de graus para porcentagem, sendo $0 \%$ o valor mais plano e $90 \%$, o mais íngreme. (Anexo F)

Cada camada apresentando as variações de valores de declividade, seleção e granulometria foram integradas e tratadas no ambiente SIG permitindo a sobreposição dos valores da Tabela 7A para a obtenção da sensibilidade final do terreno e conseqüentemente a Carta SAO Continental (Anexo G). 


\subsection{Avaliação dos parâmetros texturais para elaboração da Carta SAO}

O método de seleção da área da Carta SAO, pela intersecção das áreas das sub-bacias vulneráveis, topografia e duto, mostrou-se efetivo, por delimitar uma área reduzida de mapeamento, coleta de dados e por abranger os locais que seriam atingidos efetivamente pelo derramamento de óleo. Deve-se considerar que a Carta SAO de um duto pode apresentar centenas de quilômetros, assim, a considerável diminuição da área a ser mapeada viabiliza uma caracterização mais precisa e econômica na obtenção dos valores dos parâmetros determinantes da sensibilidade ambiental.

A análise geomorfológica, quantificada pela sua declividade, foi feita a partir de interpretação de produtos de sensoriamento remoto. As fotografias aéreas da área mostraram-se de grande valia no entendimento do relevo da área de estudo, principalmente na determinação da planície de inundação do Ribeirão do Tamanduá.

A planície do de inundação do Ribeirão do Tamanduá foi considerada, a priori, como área de sensibilidade ambiental muito alta $(I S A=5)$, independente dos valores da declividade, do tamanho e seleção de grãos obtidos, por apresentar características exclusivas como mata-ciliar em estado de recomposição, a presença de lavras de argila ball clay e areia, áreas de recreação e lazer, pesca esportiva e recreativa, fonte de água para a dessedentação de animais, irrigação de plantios de subsistência e por ser importante afluente do Rio Pardo, pertencente a UGRHI Pardo - 4, (IGC, 1996).

A escala em que foi confeccionada a Carta SAO do Ribeirão do Tamanduá, 1:60 000 (Anexo G), apresenta detalhes aceitáveis para este tipo de trabalho, embora o ideal fosse a sua confecção nas escalas 1:10 000 ou 1:25 000 . 
As bases cartográficas temáticas utilizadas para a elaboração da Carta SAO devem ter a maior escala de detalhe possível; para a área experimental foram utilizadas aquelas disponíveis em bibliotecas e órgãos públicos. Entretanto, a escala do mapa geológico $(1: 500$ 000) e do modelo digital de terreno (1:100 000) apresentam escalas com pouco detalhe. A escala ideal para o desenvolvimento desse tipo de trabalho seria de 1:10 000 até 1:50 000.

A diferença entre a escala de cada camada do banco de dados, pode ter resultado em imprecisões, porém não modificam nem invalidam o desenvolvimento da aplicação do método e parâmetros na área experimental. A dificuldade de obtenção, ou até a mesmo a inexistência, de mapeamentos e bases temáticas e cartográficas, em escalas de detalhe, forçam a adoção de uma tolerância e interpretação na sobreposição dos dados.

Estudos realizados sobre a textura dos sedimentos inconsolidados foram a fonte de informação mais adequada para escolha dos parâmetros sedimentares. Trabalhos desenvolvidos por Beard e Weyl (1973) e Nagtegaal (1978) mostram-se como fontes importantes na obtenção de valores e no entendimento da relação entre a porosidade e permeabilidade, como o tamanho e seleção de grãos. Entretanto, por apresentarem a relação da porosidade versus a permeabilidade de sedimentos francamente arenosos e misturados artificialmente, foram excluídos sedimentos finos. Por estudarem sedimentos com $95 \%$ de areia em sua constituição, a inexistência da obtenção de valores de porosidade e permeabilidade de sedimentos finos e com seleção pobre ou muito pobre de grãos, foi impossível a classificação de sedimentos argilosos e siltosos. Esta classificação poderia ser eficaz se aplicada em áreas litorâneas onde há franca predominância de areias. 
Face ao exposto, utilizou-se aqui a divisão baseada em Peettijohn et. al. (1987) da granulometria de sedimentos e na seleção de grãos. Os dados apresentados por Beard e Weyl (1973) e Nagtegaal (1978) balizaram a divisão da escala granulométrica e de seleção dos grãos relativos à sensibilidade, bem como o entendimento de que é possível determinar a porosidade e permeabilidade do sedimento a partir das características da textura sedimentar, sem a necessidade de se realizar ensaios in situ, ou laboratoriais.

Para a análise dos dados utilizaram-se métodos geoestatísticos na determinação de valores médios e da extrapolação precisa dos valores obtidos em campo. A coleta de amostra foi realizada sobre malha de amostragem com 0 tamanho de $1 \times 1 \mathrm{~km}$ (Anexo B). A escolha deste método foi justificada pela eficiente e precisa forma de se obter e extrapolar os dados.

Os valores obtidos das amostras, seleção e tamanho de grãos, foram avaliados por métodos geoestatísticos (tabelas 8 e 9). A estimativa do variograma foi obtida por krigagem ordinária. Segundo Yamamoto (2001), a análise do variograma permite conhecer o comportamento dos valores na área de estudo. 
Tabela 8 - Ponto de coleta de sedimentos para estudo geoestatístico de granulometria (em escala $\Phi)$

\begin{tabular}{|c|c|c|c|}
\hline Pontos & X Utm & Y Utm & Granulom. \\
\hline PG-01 & 223509 & 7652619 & 1,52 \\
\hline PG-02 & 228912 & 7627711 & 2,53 \\
\hline PG-03 & 219222 & 7638783 & 5,73 \\
\hline PG-04 & 220031 & 7638609 & 5,03 \\
\hline PG-05 & 220178 & 7638589 & 2,92 \\
\hline PG-06 & 220215 & 7639079 & 5,22 \\
\hline PG-07 & 220332 & 7639345 & 2,44 \\
\hline PG-08 & 224241 & 7637946 & 4,97 \\
\hline PG-10 & 220612 & 7635924 & 2,86 \\
\hline PG-11 & 222966 & 7645079 & 7,47 \\
\hline PG-12 & 229327 & 7624740 & 2,8 \\
\hline PG-13 & 229511 & 7624004 & 3,01 \\
\hline PG-14 & 230603 & 7621514 & 2,54 \\
\hline PG-15 & 226719 & 7628040 & 2,65 \\
\hline PG-18 & 220781 & 7635592 & 2,58 \\
\hline PG-19 & 222961 & 7631979 & 3,44 \\
\hline PG-20 & 227817 & 7634896 & 4,2 \\
\hline PG-22 & 228999 & 7620402 & 2,02 \\
\hline PG-23 & 229038 & 7620388 & 2,21 \\
\hline PG-24 & 229038 & 7620388 & 2,42 \\
\hline PG-25 & 229775 & 7620735 & 2,72 \\
\hline PG-26 & 230445 & 7621373 & 1,81 \\
\hline PG-27 & 230728 & 7621339 & 2,56 \\
\hline PG-28 & 230993 & 7619998 & 2,04 \\
\hline PG-29 & 231231 & 7619072 & 2,31 \\
\hline PG-30 & 231432 & 7617926 & 2,48 \\
\hline PG-31 & 232009 & 7618052 & 2,77 \\
\hline PG-32 & 232448 & 7617053 & 2,05 \\
\hline PG-33 & 230000 & 7619000 & 2,15 \\
\hline PG-34 & 229452 & 7621815 & 1,99 \\
\hline PG-35 & 229937 & 7622508 & 2,62 \\
\hline PG-36 & 228851 & 7627502 & 2,67 \\
\hline PG-37 & 228890 & 7626008 & 2,39 \\
\hline PG-38 & 227789 & 7627701 & 2,57 \\
\hline PG-39 & 226848 & 7629185 & 2,24 \\
\hline PG-40 & 227729 & 7629252 & 2,27 \\
\hline PG-41 & 227894 & 7628983 & 2,64 \\
\hline PG-42 & 227166 & 7630467 & 2,33 \\
\hline PG-43 & 227696 & 7630681 & 2,03 \\
\hline PG-44 & 227819 & 7629995 & 2,49 \\
\hline PG-45 & 218053 & 7636060 & 2,47 \\
\hline PG-46 & 217568 & 7636090 & 2,27 \\
\hline & & & \\
\hline
\end{tabular}

\begin{tabular}{|c|c|c|c|}
\hline PG-47 & 218788 & 7635327 & 2,30 \\
\hline PG-48 & 218025 & 7635375 & 2.90 \\
\hline PG-49 & 226040 & 7627374 & 2,53 \\
\hline PG-50 & 226938 & 7627504 & 2,56 \\
\hline PG-51 & 227944 & 7627068 & 2,48 \\
\hline PG-52 & 228063 & 7626445 & 2,53 \\
\hline PG-53 & 227211 & 7626364 & 2,57 \\
\hline PG-54 & 220012 & 7634081 & 2,98 \\
\hline PG-55 & 221079 & 7633704 & 2,49 \\
\hline PG-56 & 222171 & 7633952 & 2,90 \\
\hline PG-57 & 221967 & 7634800 & 2,30 \\
\hline PG-58 & 221242 & 7634949 & 2,97 \\
\hline PG-59 & 220975 & 7635437 & 3,05 \\
\hline PG-60 & 223060 & 7635079 & 2,28 \\
\hline PG-61 & 224063 & 7635434 & 2,56 \\
\hline PG-62 & 225024 & 7635168 & 2,71 \\
\hline PG-63 & 226075 & 7635805 & 1,85 \\
\hline PG-64 & 226124 & 7636641 & 1,98 \\
\hline PG-65 & 224952 & 7635917 & 2,52 \\
\hline PG-66 & 224010 & 7635898 & 2,06 \\
\hline PG-67 & 224582 & 7637011 & 1,98 \\
\hline PG-68 & 224102 & 7633955 & 2,50 \\
\hline PG-69 & 223914 & 7633221 & 2,56 \\
\hline PG-70 & 222732 & 7633748 & 2,84 \\
\hline PG-71 & 225072 & 7633057 & 2,15 \\
\hline PG-72 & 224714 & 7633835 & 2,39 \\
\hline PG-73 & 225947 & 7633069 & 2,40 \\
\hline PG-74 & 226058 & 7633867 & 2,56 \\
\hline PG-75 & 226416 & 7634886 & 2,36 \\
\hline PG-76 & 226897 & 7633779 & 1,84 \\
\hline PG-77 & 227284 & 7632905 & 2,31 \\
\hline PG-78 & 227685 & 7632990 & 2,34 \\
\hline PG-79 & 227763 & 7631835 & 2,31 \\
\hline PG-80 & 226712 & 7631567 & 1,95 \\
\hline PG-81 & 226173 & 7632397 & 2,17 \\
\hline PG-82 & 227250 & 7631279 & 2,24 \\
\hline PG-83 & 225994 & 7631120 & 2,36 \\
\hline PG-84 & 224883 & 7630840 & 2,43 \\
\hline PG-85 & 224567 & 7631685 & 2,34 \\
\hline PG-86 & 224092 & 7631852 & 2,28 \\
\hline PG-87 & 221962 & 7632200 & 2,35 \\
\hline PG-88 & 221914 & 7633152 & 3,14 \\
\hline PG-89 & 222712 & 7632797 & 2,98 \\
\hline
\end{tabular}


Tabela 9 - Ponto de coleta de sedimentos para análise geoestatística da Seleção ( $\sigma$ do diâmetro $\Phi$ )

\begin{tabular}{|c|c|c|c|}
\hline Pontos & X Utm & Y Utm & Seleção \\
\hline PG-01 & 223509 & 7652619 & 1,28 \\
\hline PG-02 & 228912 & 7627711 & 2,22 \\
\hline PG-03 & 219222 & 7638783 & 3,22 \\
\hline PG-04 & 220031 & 7638609 & 3,48 \\
\hline PG-05 & 220178 & 7638589 & 1,85 \\
\hline PG-06 & 220215 & 7639079 & 2,87 \\
\hline PG-07 & 220332 & 7639345 & 1,7 \\
\hline PG-08 & 224241 & 7637946 & 2,97 \\
\hline PG-10 & 220612 & 7635924 & 1,94 \\
\hline PG-11 & 222966 & 7645079 & 2,32 \\
\hline PG-12 & 229327 & 7624740 & 1,25 \\
\hline PG-13 & 229511 & 7624004 & 2,17 \\
\hline PG-14 & 230603 & 7621514 & 1,82 \\
\hline PG-15 & 226719 & 7628040 & 1,41 \\
\hline PG-18 & 220781 & 7635592 & 2,41 \\
\hline PG-19 & 222961 & 7631979 & 2,48 \\
\hline PG-20 & 227817 & 7634896 & 2,37 \\
\hline PG-22 & 228999 & 7620402 & 1,98 \\
\hline PG-23 & 229038 & 7620388 & 2,58 \\
\hline PG-24 & 229038 & 7620388 & 2,15 \\
\hline PG-25 & 229775 & 7620735 & 1,80 \\
\hline PG-26 & 230445 & 7621373 & 1,41 \\
\hline PG-27 & 230728 & 7621339 & 1,80 \\
\hline PG-28 & 230993 & 7619998 & 1,25 \\
\hline PG-29 & 231231 & 7619072 & 1,38 \\
\hline PG-30 & 231432 & 7617926 & 1,49 \\
\hline PG-31 & 232009 & 7618052 & 2,04 \\
\hline PG-32 & 232448 & 7617053 & 0,88 \\
\hline PG-33 & 230000 & 7619000 & 1,09 \\
\hline PG-34 & 229452 & 7621815 & 0,99 \\
\hline PG-35 & 229937 & 7622508 & 1,29 \\
\hline PG-36 & 228851 & 7627502 & 1,31 \\
\hline PG-37 & 228890 & 7626008 & 1,18 \\
\hline PG-38 & 227789 & 7627701 & 1,04 \\
\hline PG-39 & 226848 & 7629185 & 1,11 \\
\hline PG-40 & 227729 & 7629252 & 1,08 \\
\hline PG-41 & 227894 & 7628983 & 1,36 \\
\hline PG-42 & 227166 & 7630467 & 1,02 \\
\hline PG-43 & 227696 & 7630681 & 0,74 \\
\hline PG-44 & 227819 & 7629995 & 1,40 \\
\hline PG-45 & 218053 & 7636060 & 1,45 \\
\hline PG-46 & 217568 & 7636090 & 1,35 \\
\hline
\end{tabular}

\begin{tabular}{|c|c|c|c|}
\hline PG-47 & 218788 & 7635327 & 1,37 \\
\hline PG-48 & 218025 & 7635375 & 1,39 \\
\hline PG-49 & 226040 & 7627374 & 1,24 \\
\hline PG-50 & 226938 & 7627504 & 1,49 \\
\hline PG-51 & 227944 & 7627068 & 1,28 \\
\hline PG-52 & 228063 & 7626445 & 1,51 \\
\hline PG-53 & 227211 & 7626364 & 1,31 \\
\hline PG-54 & 220012 & 7634081 & 1,77 \\
\hline PG-55 & 221079 & 7633704 & 1,61 \\
\hline PG-56 & 222171 & 7633952 & 1,81 \\
\hline PG-57 & 221967 & 7634800 & 1,23 \\
\hline PG-58 & 221242 & 7634949 & 1,72 \\
\hline PG-59 & 220975 & 7635437 & 1,48 \\
\hline PG-60 & 223060 & 7635079 & 1,26 \\
\hline PG-61 & 224063 & 7635434 & 1,46 \\
\hline PG-62 & 225024 & 7635168 & 1,54 \\
\hline PG-63 & 226075 & 7635805 & 1,10 \\
\hline PG-64 & 226124 & 7636641 & 0,99 \\
\hline PG-65 & 224952 & 7635917 & 1,28 \\
\hline PG-66 & 224010 & 7635898 & 0,90 \\
\hline PG-67 & 224582 & 7637011 & 0,75 \\
\hline PG-68 & 224102 & 7633955 & 1,20 \\
\hline PG-69 & 223914 & 7633221 & 1,19 \\
\hline PG-70 & 222732 & 7633748 & 1,54 \\
\hline PG-71 & 225072 & 7633057 & 1,32 \\
\hline PG-72 & 224714 & 7633835 & 1,17 \\
\hline PG-73 & 225947 & 7633069 & 1,46 \\
\hline PG-74 & 226058 & 7633867 & 1,29 \\
\hline PG-75 & 226416 & 7634886 & 0,99 \\
\hline PG-76 & 226897 & 7633779 & 1,11 \\
\hline PG-77 & 227284 & 7632905 & 1,20 \\
\hline PG-78 & 227685 & 7632990 & 1,00 \\
\hline PG-79 & 227763 & 7631835 & 1,18 \\
\hline PG-80 & 226712 & 7631567 & 0,65 \\
\hline PG-81 & 226173 & 7632397 & 0,85 \\
\hline PG-82 & 227250 & 7631279 & 0,99 \\
\hline PG-83 & 225994 & 7631120 & 0,80 \\
\hline PG-84 & 224883 & 7630840 & 0,99 \\
\hline PG-85 & 224567 & 7631685 & 0,87 \\
\hline PG-86 & 224092 & 7631852 & 0,59 \\
\hline PG-87 & 221962 & 7632200 & 1,10 \\
\hline PG-88 & 221914 & 7633152 & 1,34 \\
\hline PG-89 & 222712 & 7632797 & 1,36 \\
\hline
\end{tabular}


Na figuras $37 \mathrm{~A}$ e B, pode-se observar os gráficos dos variogramas dos valores de tamanho e seleção de grãos obtidos na área experimental do Ribeirão do Tamanduá. Os gráficos A e B mostram uma concentração dos dados com poucos
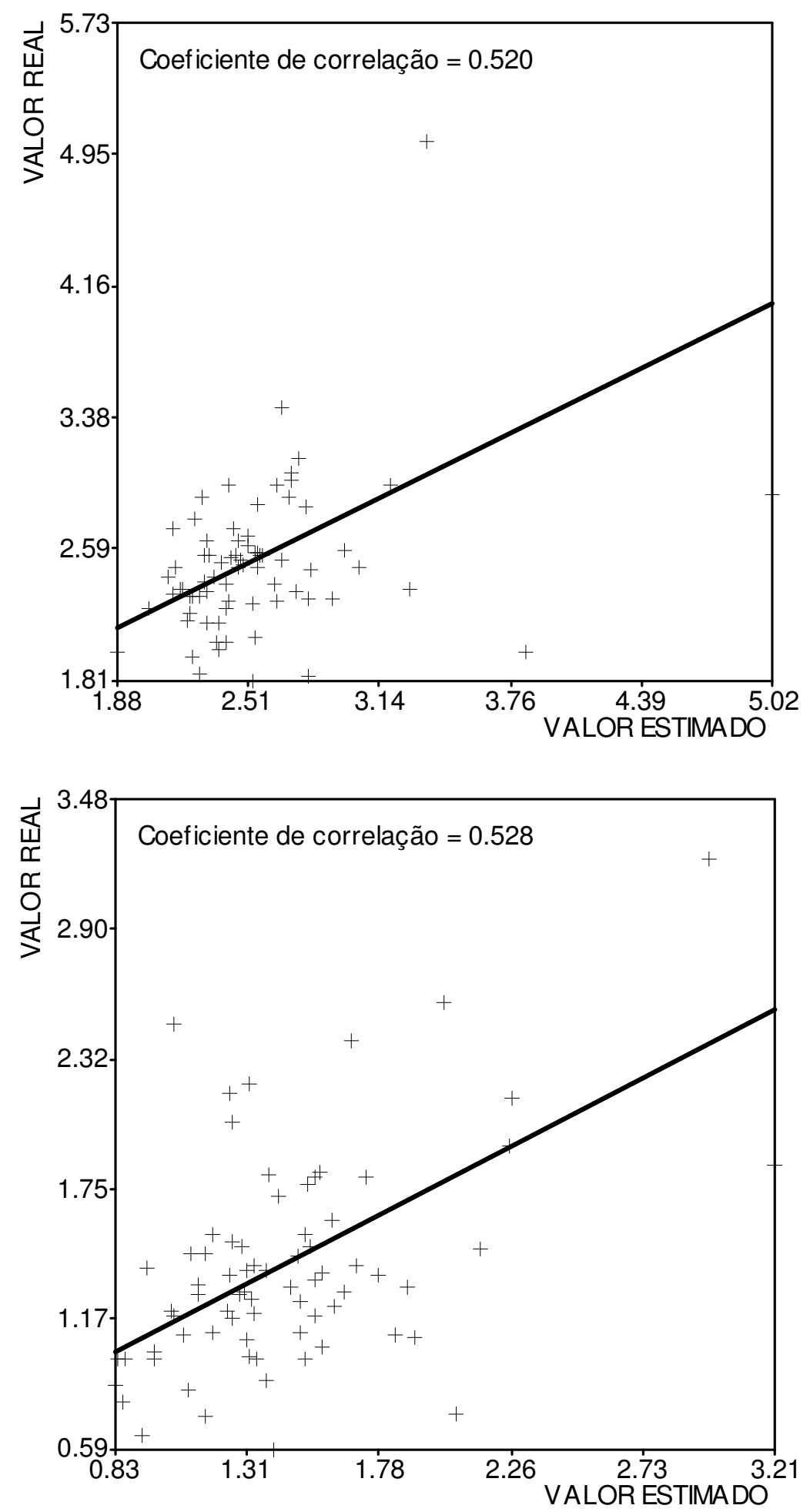

Figura 37 A e B - variabilidade espacial dos dados interpolados da área. 
valores destoantes para ambos parâmetros.

Nas figuras 38 A e B, observa-se a variabilidade espacial dos dados interpolados da área de estudo, apresentam-se estruturados de modo que é possível observar uma variabilidade orientada pelas características topográficas, estratigráficas e litológicas da área de estudo. O variograma foi ajustado às curvas gaussianas nas direções NE e SE.
$+=45$
$\diamond=135$

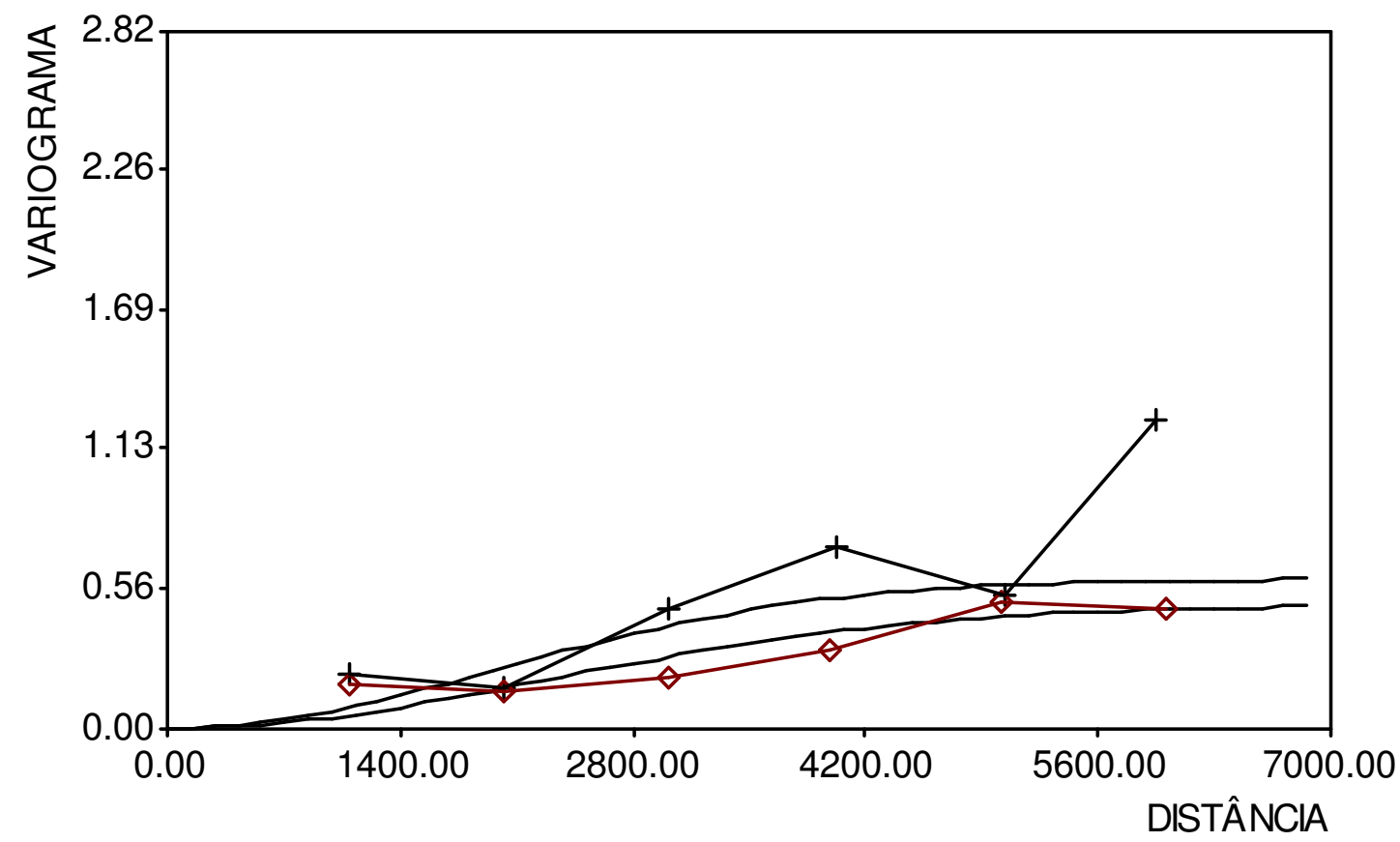

Figura $38 \mathrm{~A}$, resultado da interpolação do variograma por krigagem ordinária. 


$$
+=45 \quad \diamond=135
$$

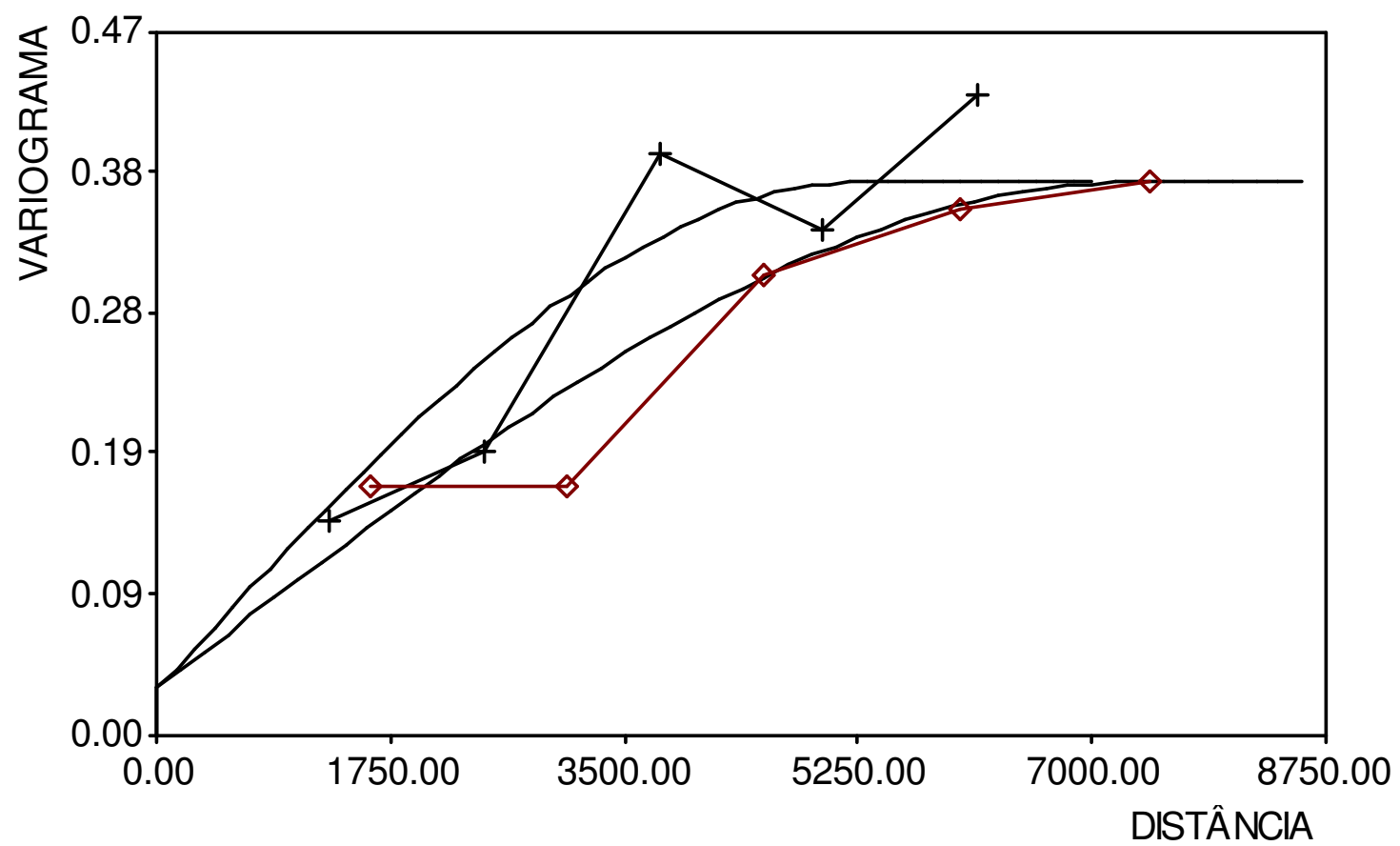

Figura 38 B - resultado da interpolação do variograma por krigagem ordinária.

Na figura 39 pode-se observar o resultado da interpolação do variograma por krigagem ordinária, realizada pela equação do quadrado da distância entre as variáveis regionalizadas, obteve-se o mapa de isovalores da granulometria da área de estudo. 


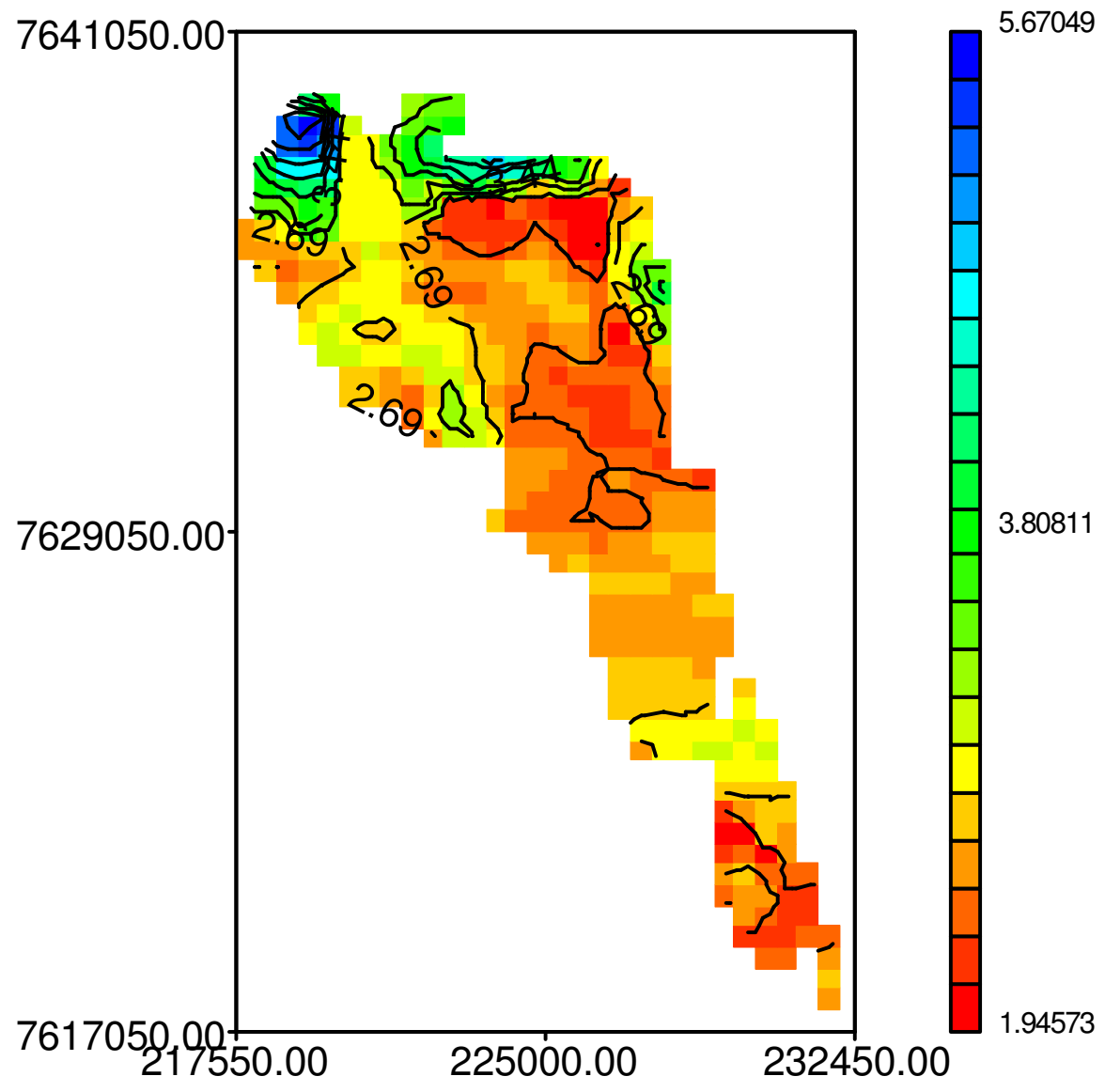

Figura 39 - Mapa georreferenciado dos isovalores da granulometria obtido na área do Ribeirão do Tamanduá

A análise geoestatística dos valores obtidos para a interpolação da seleção dos grãos foi realizada pelo mesmo método. A figura 40 apresenta o comportamento dos valores obtidos no variograma. 


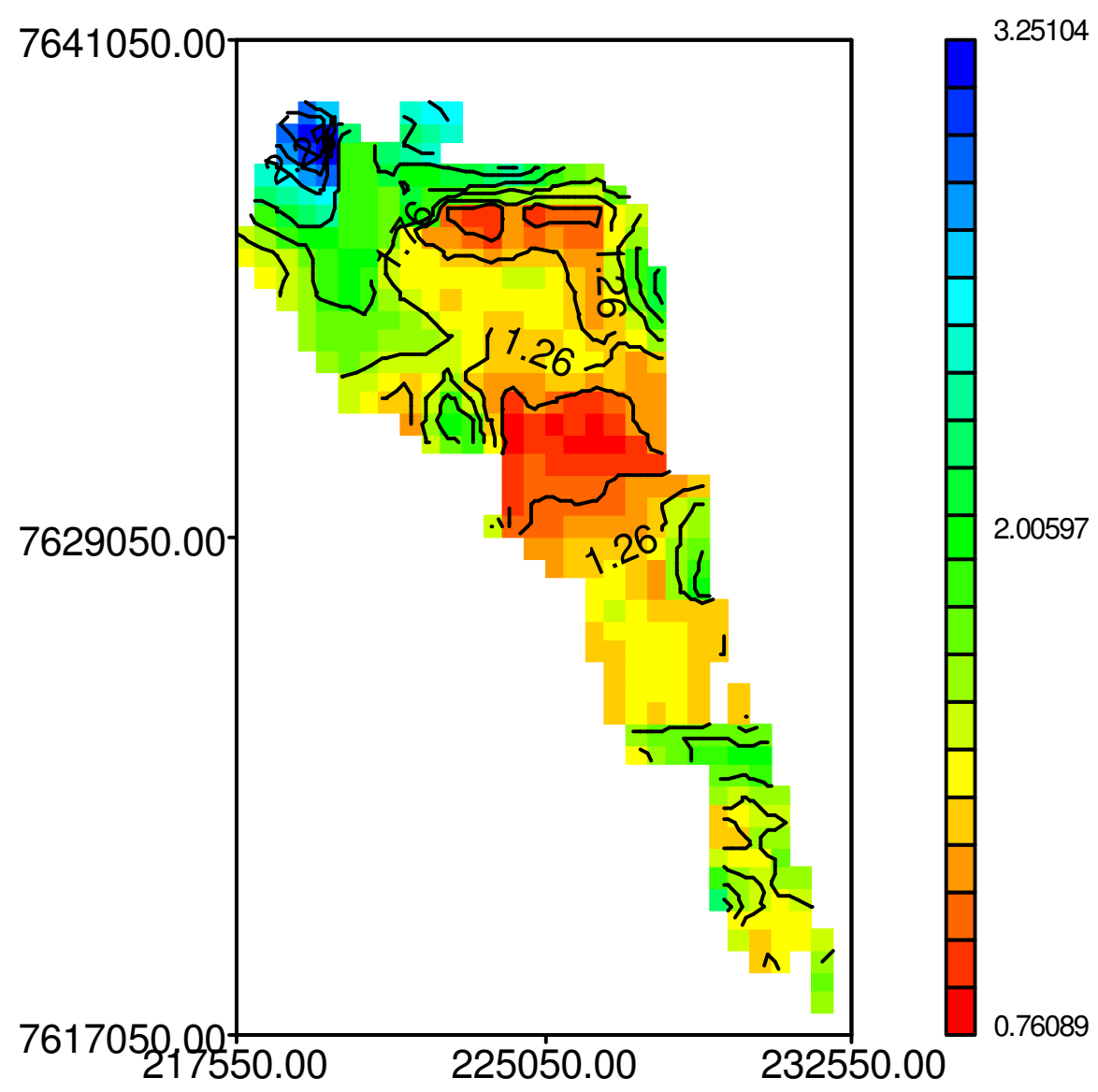

Figura 40 - Mapa georreferenciado dos isovalores da seleção de grãos obtido na área do Ribeirão do Tamanduá.

Os pesos da fórmula 1 foram definidos como um (01) para todos os parâmetros calculados. A constância do valor dos pesos justificou-se pela impossibilidade de determinar qual dos parâmetros analisados apresenta maior influência na sensibilidade ambiental.

Peso de notas da equação poderia ser adotado valores maiores para a granulometria, pois segundo Beard e Weyl (1973) e Nagtegaal (1978) e mesmo outros autores, por ser este é um parâmetro que apresenta grande influência nos valores da porosidade. A declividade também poderia ter o peso maior, por apresentar grande importância na infiltração e espalhamento do óleo pelo terreno.

O uso da geoestatística e da análise dos dados como, variáveis regionalizadas e do programa aplicativo de SIG, são ferramentas importantes na elaboração da 
Carta SAO, pois permitiram maior precisão e clareza na interpretação dos dados. A geoestatística mostrou-se excelente ferramenta, que integrado ao SIG, permitiu grande precisão no tratamento dos dados amostrais.

Por terem sido estudados sedimentos superficiais, sujeitos a atividades agropecuárias, deve-se considerar que tenham características distintas em alguns aspectos como compactação, cimentação e seleção de grãos, frente as informações bibliográficas obtidas a partir de estudos da geologia do petróleo e de reservatórios.

Este trabalho pretende ser, não somente uma contribuição ao tema, mas um marco de discussão e suscitador de questionamentos de metodologias sobre a elaboração de cartas temáticas ambientais, principalmente para ambientes continentais.

A precisão dos parâmetros utilizados para a determinação de permeabilidade e porosidade pode apresentar variações e até mesmo imprecisões, entretanto de acordo com o entendimento de resposta a este tipo de emergência, o principal, é o rápido atendimento, e a contenção rápida e eficaz da fonte de vazamento. A sensibilidade ambiental é excelente ferramenta que auxilia na tomada de decisões de predição de trajetória e de proteção prioritária de áreas de alta sensibilidade ao óleo

A Carta SAO aqui é compreendida como apenas uma das partes necessárias para o estudo da sensibilidade do meio, pois há parâmetros tão importantes quanto ao sedimentar que aqui estão ausentes. Questões sobre as características da biota, e a socioeconômica ainda mostram-se carentes de mais estudos. Não contempla parâmetros, não menos necessários, os do meio biótico e socioeconômico, delegados a profissionais e acadêmicos das respectivas áreas. 


\section{Conclusões}

Os principais parâmetros sedimentares que se mostraram mais relevantes na determinação da sensibilidade ambiental de áreas de sedimentos e rochas arenosas, sujeitas a derramamento de óleo, foram a granulometria e a seleção dos grãos. A relação com o relevo, expressa aqui pela declividade, a partir do modelo digital de terreno, mostrou-se como parâmetro adicional significativo na determinação da sensibilidade e do comportamento do óleo na área estudada.

Os critérios utilizados foram de grande valia na determinação das definições das bacias vulneráveis, e conseqüente diminuição em área da região a ser submetida aos levantamentos para cartas SAO, o que vem no sentido de otimizar os trabalhos e reduzir custos.

A área de estudo, representada por parte da Bacia Hidrográfica do Ribeirão Tamanduá, apresentou-se com pouca variação de parâmetros e até certo ponto monótona em diversidade de informações e dados; porém os parâmetros propostos (granulometria e seleção de grãos) se mostraram relevantes como critério de zoneamento para carta SAO, sendo recomendado o uso desses para ampliação dos levantamentos para esse fim nas demais exposições da Formação Botucatu e, conforme o caso, também da Formação Pirambóia, por constituírem, essas unidades, rocha-reservatório do Sistema Aqüífero Guarani. 


\section{Referências Bibliográficas.}

API e NOAA. 1994. American Petroleum Institute e National Oceanic Atmospheric Administration. (Hazardous Materials Response e Assessment Division). Options for Minimizing Environmental Impacts of Freshwater Spill Response. 135p.

ARAÚJO, L. M.; FRANÇA, A. B. e POTTER, P. E. 1995. Aqüífero Gigante do Mercosul no Brasil, Argentina, Paraguai e Uruguai: Mapas Hidrogeológicos das Formações Botucatu, Pirambóia, Rosário do Sul, Buena Vista, Misiones e Tacuarembó. Curitiba. UFPR. 16p.

BEARD, D.C. e WEYL, P.K. 1973. Influence of Texture on Porosity and Permeability of Unconsolidated Sand. The American Association of Petroleum Geologist Bulletin. 57 (2): 349-369.

BENITO, G. BENITO-CALVO, A. GALLART, F. MARTIN-VIDE, J.P. REGÜES, D. e BLADÉ, E. 2001. Hydrological and Geomorfological Criteria to Evaluate the Dispersion Risk of Waste Sludge Generated by the Aznalcollar Mine Spill (SW Spain). Environmental Geology, 40 (4-5): 417-428.

CETESB - Companhia de Tecnologia de Saneamento Ambiental 2007. $<w w w . c e t e s b . s p . g o v . b r>$

DAVIS, A. D.; LONG, A.J. e WIREMAN, M. 2002. Karstic: A Sensitivity Method for Carbonate Aquifer in Karst Terrain. Environmental Geology, (42): 65-72.

DER 2003. Mapa rodoviário do Estado de São Paulo Escala 1:240.000. Departamento de Estradas de Rodagem. Governo de Estado de São Paulo. ENGEMAP.

FLOREZ, J. e MARVA, G. 2003. Porosity - velocity Distribution in Stratigraphic Sequences: the Marion-Yin Model. In: The American Association of 
Petroleum Geologists (AAPG). ANNUAL CONVENTION. SALT LAKE CITY. PDF. 5p.

FOLK, R. L. 1968. Petrology of sedimentary rocks. Austin, Hemphill Publ. Co. 170p.

FOSTER, S. e HIRATA, R. 1991. Determinación del Riesgo de Contaminación de Aguas Subterráneas. 2 ${ }^{\mathrm{a}}$ Edicto. Centro Panamericano de Ingeniería Sanitaria y Ciencias del Ambiente (CEPIS). Organización Mundial de la Salud. Lima. 81p.

FUSSELL, D. R.; GÖDJEN, H.; HAYWARD, P.; LILIE, R. H.; MARCO, A. e PANISI, C. 1981. Revised Inland Oil Spill Clean-Up Manual. Oil Spill Clean-Up Technology (Oscut) Special Task Force No 3. CONCAWE. Den Haag. 149p.

GOODMON, R. 2005. Wabamun: a major inland spill. Innovative Ventures Ltd.

Canadá. www.epa.gov/oilspill/pdfs/GoodmanR_Wabamun\%20Final.pdf

GUERRA, J. T. e CUNHA, S. B. da 1994. Geomorfologia: uma atualização de bases e conceitos. Rio de Janeiro. Bertrand Brasil. 458p.

GUNDLACH e HAYES. 1978. Vulnerability of Coastal Environments to Oil Spill Impacts. Marine Technology Society Journal. Volume 12 (4): 18-27.

HAYES, O. M.; MICHEL, J.; DAHLIN, J. A e BARTON, K. 1994. Identifying and Mapping Sensitive Resources for Inland Area Planning. <http//:epa.gov. epa/noaa>. 16pp.

IGC - Instituto Geográfico e Cartográfico 1996. Unidades Hidrográficas de Gerenciamento de Recursos Hídricos (UGRHI). Divisão municipal do Estado de São Paulo. São Paulo. Escala 1:1.000.000.

IMO - International Maritime Organization - 2007 - <http:// www.imo.org.uk> 
IPIECA e IMO - International Maritime Organization e International Petroleum Industry Environmental Conservation Association 1996. Sensitivity mapping for oil spill response. Report Series. Volume 1. 24p. <http://www. http://www.ipieca.org/>

IPT - Instituto de Pesquisas Tecnológicas do Estado de São Paulo 1981. Nota Explicativa do Mapa Geológico do Estado de São Paulo. Escala 1:500,000. São Paulo. Volume 1.

IPT - Instituto de Pesquisas Tecnológicas do Estado de São Paulo 1981. Mapa Geológico do Estado de São Paulo. Escala 1:500,000. São Paulo. Volume 2.

ITOPF - International Tankers Owners Pollution Federation Limited 2007 $<$ http://www.itopf.org/>

LEAL, A. C. 1995. Meio Ambiente e urbanização na microbacia do Areia Branca, Campinas, SP. Dissertação de Mestrado em Geociências. Rio Claro. UNESP.

MENDES, R. F.; MINNITI, V.; LOPES, C. F.; MILANELI, J.; TORRES, C.; YOGUI, R.; RODRIGUES, G. e MARIZ, E. 2005. MARA - Elaboração de Metodologia para Análise dos Riscos Ambientais. In: RIO PIPELINE CONFERENCE E EXPOSITION. Rio de Janeiro. Instituto Brasileiro de Petróleo e Gás - IBP. (1299-05) 8p.

MMA - Ministério do Meio Ambiente 2002. Especificações e Normas Técnicas para a Elaboração de Cartas de Sensibilidade Ambiental para Derramamentos de Óleo.

NAGTEGAAL, P.J.C. 1978. Sandstone-Framework Instability as a Function of Burial Diagenesis. Journal of Geological Society of London. 135: 101-105. 
NEIVA, J. 1993. Conheça o petróleo. 6ª edição. Rio de Janeiro. Ed. Expressão e Cultura. $187 \mathrm{p}$.

NOAA - National Oceanic and Atmospheric Administration 1997. Environmental Sensitivity Index Guidelines, version 2.0. Technical Memorandum NOS ORCA 115. Hazardous Materials Response and Assessment Division, National Oceanic and Atmospheric Administration. Seattle. 79 p.

PETROBRAS 2002. Mapa dos oledutos e gasodutos do Brasil. Escala 1:6.000.000. Transpetro, Petrobras E\&P, IBGE, Marinha, GISMAP. Rio de Janeiro.

OLIVEIRA, W, J. DE; BRAUN, O. P. G.; PERREIRA JR, E. R.; NASCIMENTO, V. L. DO; BRAGA FILHO; J. B.; PINESCHI, R.; RODRIGUES, A. F.; LOEIRO, R. T. M. e BIZERRIL, C. R. S. F. 2003. Mapas de Sensibilidade Ambiental para Faixas de Dutos Terrestres. In: RIO PIPELINE CONFERENCE E EXPOSITION Rio de Janeiro. Instituto Brasileiro de Petróleo e Gás - IBP. $9 p$.

OWENS, E. H. 2002 Response Strategies for Spills on Land. IN: SPILL SCIENCE E TECHNOLOGY BULLETIN. 7, (3-4): 115-177. Grã Bretanha. Ed. Elsevier. PEETTIJOHN, F. J; POTTER, P. E; e SIEVER, R. 1987 Sand and sandstone. 2a edição. Springer-Verlag. Nova lorque. 553 p.

PETRI, S. e FÚLFARO, V.J. 1983. Geologia do Brasil. São Paulo. EDUSP.631p.

PRESSINOTTI, M; M; N. 1991. Caracterização Geológica e Aspectos Genéticos dos Depósitos de Argilas Tipo Ball Clay de São Simão, SP. Dissertação de Mestrado. Instituto de Geociências. Universidade de São Paulo. USP, São Paulo. 141 p.

POWERS, M.C. 1953. A new roundness scale for sedimentary particles. Journal of Sedimentary Petrology, 23:117-119 
ROSS, J.; L.; S. e MOROZ, I.; C. 1997. Mapa geomorfológico do Estado de São Paulo. São Paulo. FFLCH/USP e IPT/FAPESP. Escala 1:500.000.

SELLEY, R.C. 1998. Elements of Petroleum Geology. 2a Edição. Londres. Academic Press. 470p.

STALCUP, D.; YOSHIOKA, G.; MANTUS, E. e KAIMAN, B. 1997. Characteristics of Oil Spills: Inland Versus Coastal. In: PROCEEDINGS OF THE 1997 INTERNATIONAL OIL SPILL CONFERENCE. EPA. 357: (1-2).

TRANSPETRO - Petrobras Transporte S.A. 2007. <http://www.transpetro.com.br> WENDLAND, E; CUNHA, A. T; RABELO, J. L. 2004. Taxa de infiltração em zona de afloramento do Aqüifero Guarani. IN: ANAIS DO XIII CONGRESSO BRASILEIRO DE ÁGUAS SUBTERRÂNEAS. Cuiabá. São Paulo. ABAS. (1) $1-17$. 
YAMAMOTO, J. K. 2001. Avaliação e classificação de reservas minerais. São Paulo. EDUSP. 226 p.

YOSHIOKA, G. e CARPENTER M. 2002. ICF Consulting Fairfax. Virginia. Characteristics of Reported Inland and Coastal Oil Spills. $<$ http://www.epa.gov/oilspill/pdfs/carpenterpaper.pdf. $>9 p$

ZALÁN, P. V.; WOLF, S.; CONCEIÇÃO, J. C. J.; MARQUES, A.; ASTOLFI, M. A. M.; VIEIRA, I. S.; APPI, V. T. e ZANOTTO, O. A. 1990. Sinéclises Intracratônicas - Bacia do Paraná - (135-168p.) In: Origem e evolução de bacias sedimentares. Coordenador: GABAGLIA, G.P.R. e MILANI, E.J. Rio de Janeiro. Petrobras. $415 p$ 
Anexo A 
Anexo B 
Anexo C 
Anexo D 


\section{Anexo E}


Anexo F 
Anexo G 